Portland State University

PDXScholar

Spring 7-12-2018

\title{
Christians and Jerusalem in the Fourth Century CE: a Study of Eusebius of Caesarea, Cyril of Jerusalem, and the Bordeaux Pilgrim
}

Stephen David Green

Portland State University

Follow this and additional works at: https://pdxscholar.library.pdx.edu/open_access_etds

Part of the History Commons, and the History of Christianity Commons Let us know how access to this document benefits you.

\section{Recommended Citation}

Green, Stephen David, "Christians and Jerusalem in the Fourth Century CE: a Study of Eusebius of Caesarea, Cyril of Jerusalem, and the Bordeaux Pilgrim" (2018). Dissertations and Theses. Paper 4442. https://doi.org/10.15760/etd.6326

This Thesis is brought to you for free and open access. It has been accepted for inclusion in Dissertations and Theses by an authorized administrator of PDXScholar. Please contact us if we can make this document more accessible: pdxscholar@pdx.edu. 
Christians and Jerusalem in the Fourth Century CE:

A Study of Eusebius of Caesarea, Cyril of Jerusalem, and the Bordeaux Pilgrim

by

Stephen David Green

A thesis submitted in partial fulfillment of the requirements for the degree of

Master of the Arts

in

History

Thesis Committee:

Brian Turner, Chair

David Johnson

John Ott

Loren Spielman

Portland State University

2018 
(C) 2018 Stephen David Green 


\begin{abstract}
This thesis addresses Constantine's developments of the Roman province of Palaestina. It analyzes two important Christian bishops, Eusebius of Caesarea and Cyril of Jerusalem, and one nameless Christian traveler, the Bordeaux pilgrim, to illuminate how fourth-century Christians understood these developments. This study examines the surviving writings of these Christian authors: the Bordeaux Itinerary, Cyril's Catechetical Lectures, and Eusebius's Ecclesiastical History, Onomasticon, Preparation of the Gospel, Proof of the Gospel, and the Life of Constantine, and the archaeological remains of several Constantinian basilicas to interpret their views of the imperial attentions that were being poured into the land. Together these accounts provide views of fourth-century Palaestina and Jerusalem that when combined more fully illuminate how Christians understood Constantine's Holy Land policy.

This study focuses on Constantine's developments of the city of Jerusalem, primarily the so-called Triad of Churches (The church of the Nativity, the Eleona, and the Holy Sepulchre) built in and around the city. It likewise considers the countryside of Palaestina outside of Jerusalem. While some Christians were resistant to the developments of Jerusalem, our sources reveal how many Christians supported, or at least desired to experience, the newly developing Christian Holy Land.

This thesis argues that most of the discrepancies over the city of Jerusalem between our sources, especially Eusebius and Cyril, developed from long-standing political tensions between the cities of Caesarea and Jerusalem. The Bordeaux pilgrim, on the other hand, traveled across the Roman Empire to see and experience the developing sites throughout the land with no interest in local political debates. With this added
\end{abstract}


perspective we can see how Christians, separated from the positions of church fathers, experienced the developing Holy Land. 


\section{Dedication}

I dedicate this thesis to my parents.

They not only made this thesis possible, but enjoyable. 


\section{Table of Contents}

Abstract........................................................................

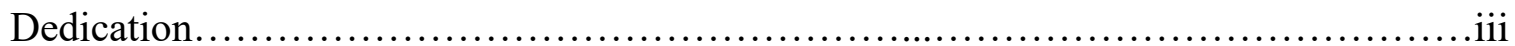

\section{Chapter 1}

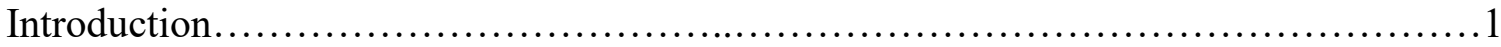

Chapter 2

Constantine, the Bishops, and the Pilgrim....

Chapter 3

The Triad of Churches....

Chapter 4

Palaestina and Jerusalem

Chapter 5

Conclusion............................................................. 107

Bibliography........................................................... 114

Appendix................................................................. 122 


\section{Chapter 1}

\section{Introduction}

Christians have not always considered Jerusalem sacred. Although they

recognized Palaestina as the province in which Jesus Christ was born, travelled,

preached, and, eventually, died and rose again, in the centuries after the crucifixion,

Christians did not consider Jerusalem to hold much spiritual significance. ${ }^{1}$ In the fourth

century, under the patronage of Emperor Constantine, Palaestina underwent significant

development and grew into a position of wealth and significance. ${ }^{2}$ At the same time,

Christian attitudes towards Jerusalem began to change.

\footnotetext{
${ }^{1}$ John Winter Crowfoot, Early Churches in Palestine (Schweich Lectures; 1937. College Park, Md.: McGrath PubCo, 1971), 1-5; Jan Willem Drijvers, Cyril of Jerusalem: Bishop and City (Leiden: Brill, 2004), 1-11; Kenneth G. Holum, "Hadrian and St. Helena: Imperial Travel and the Origins of Christian Holy Land Pilgrimage," in The Blessings of Pilgrimage, ed. Robert G. Ousterhout (Illinois Byzantine Studies; 1. Urbana: University of Illinois Press, 1990), 70; Oded Irshai, "The Christian Appropriation of Jerusalem in the Fourth Century: The Case of the Bordeaux Pilgrim," The Jewish Quarterly Review 90.4 (Fall 2009): 465-469; Noel Lenski, "Empresses in the Holy Land: The Creation of a Christian Utopia in Late Antique Palestine" in Travel, Communication, and Geography in Late Antiquity: Sacred and Profane, ed. Linda Ellis and Frank Kidner (Burlington, VT: Ashgate, 2004): 113-25; Blake Leyerle, "Landscape as Cartography in Early Christian Pilgrimage Narratives," Journal of the American Academy of Religion 64.1 (1995): 119-20; Pierre Maraval, "The Earliest Phase of Christian Pilgrimage in the Near East (before the 7th Century)," Dumbarton Oaks Papers 56 (2002): 63-67; Wendy Pullan, “'Intermingled Until the End of Time': Ambiguity as a Central Condition of Early Christian Pilgrimage," in Pilgrimage in Graeco-Roman \& Early Christian Antiquity, ed. Jas Elsner and Ian Rutherford (Oxford: Oxford University Press, 2007), 389-400; Jonathan Z. Smith, To Take Place: Toward Theory in Ritual (Chicago: University of Chicago Press, 1987), 84-8; Julie Ann Smith, "My Lord's Native Land: Mapping the Christian Holy Land," Church History 76.1 (Mar., 2007): 1-6; Peter W. L. Walker, Holy City, Holy Places?: Christian Attitudes to Jerusalem and the Holy Land in the Fourth Century (Oxford Early Christian Studies. Oxford: New York: Clarendon Press; Oxford University Press, 1990), 11; David Sutherland Wallace-Hadrill, Eusebius of Caesarea (London: ARMowbray, 1960), 21; Carl Umhau Wolf, "Eusebius of Caesarea and the Onomasticon," The Biblical Archaeologist 27.3 (Sept. 1964): 81-82. Hunt argues that even before Constantine's reforms there was a Christian understanding of Jerusalem as a "holy place" and there were also Christian pilgrims to Jerusalem; E. D. Hunt, "Were there Christian Pilgrims before Constantine?" in Pilgrimage Explored, ed. J. Stopford (University of York: York Medieval Press, 1999), 25-6. For the purposes of this Thesis, all dates are in CE unless otherwise specified, all abbreviations for sources according to the Oxford Classical Dictionary, and all Latin and translations of the It. Burg. are in the appendix.

${ }^{2}$ Gregory T. Armstrong, "Constantine's Churches: Symbol and Structure," Journal of the Society of Architectural Historians 33.1 (1974): 13-16; Drijvers, Cyril 1-6; Yaron Z. Eliav, God's Mountain: The Temple Mount in Time, Place, and Memory (Baltimore: Johns Hopkins University Press, 2005), 83-86;
} 
In the early-fourth century Constantine officially ended Christian persecution and began his work to unify the heavily divided Church in order to transform it into a single body that he could lead. ${ }^{3}$ One way that Constantine worked to unify the Christian Church was the development of Palaestina into a new Christian Holy Land. ${ }^{4}$ Christians throughout Palaestina interpreted Constantine's developments of the region in a variety of ways. This thesis compares and analyzes three separate fourth-century Christian accounts of the region and the city of Jerusalem. Eusebius, the bishop of Caesarea in the early to mid-fourth century, resisted the developing position of Jerusalem, as it threatened his personal power in Caesarea. A decade later, Cyril, bishop of Jerusalem, aggressively endorsed a pro-Jerusalem policy in his lectures and writings. Finally, we have the Itinerarium Burdigalense (the Bordeaux Itinerary) written in 333. The pilgrim responsible for writing this itinerary was most likely not a Church leader, nor someone who held any political connections to either city in Palaestina. These three sources, therefore, afford us the opportunity to illuminate how Christians of different ranks and

\footnotetext{
Holum, "Hadrian and St. Helena," 66; David Stone Potter, Constantine the Emperor (Oxford: Oxford University Press, 2013), 275-84; Lawrence H. Schiffman, "Jerusalem: Twice Destroyed, Twice Rebuilt," The Classical World 97.1 (2003): 36-7; Seth Schwartz, Imperialism and Jewish Society, 200 B.C.E. to 640 C.E. Jews, Christians, and Muslims from the Ancient to the Modern World (Princeton: Princeton University Press, 2001), 203-14; Smith, To Take Place, 84-8; Jan R. Stenger, "Eusebius and the Representation of the Holy Land," in Brill's Companion to Ancient Geography: The Inhabited World in Greek and Roman Tradition, ed. Serena Bianchetti, Michele R. Cataudella and Hans-Joachim Gehrke (Leiden: Brill, 2016), 382-87; William Telfer, Cyril of Jerusalem and Nemesius of Emesa (Philadelphia: Westminster Press, 1955), 43-7; Yoram Tsafrir, Ancient Churches Revealed (Jerusalem: Israel Exploration Society, 1993), 1-5; Yoram Tsafrir, "Byzantine Jerusalem: The Configuration of a Christian City," in Jerusalem: Its Sanctity and Centrality to Judaism, Christianity, and Islam, ed. Lee I. Levine (New York: Continuum, 1999), 13339; Annabel Jane Wharton, "The Baptistry of the Holy Sepulcher in Jerusalem and the Politics of Sacred Landscape," Dumbarton Oaks Papers 46 (1992): 321-22; Walker, Holy City, 3-15.

${ }^{3}$ Potter, Constantine, 275-84, Irshai, "The Christian Appropriation of Jerusalem," 465-67.

${ }^{4}$ Drijvers, Cyril,12; Holum, "Hadrian and St. Helena," 69-71; Irshai, "The Christian Appropriation of Jerusalem," 465-69; Schiffman, "Jerusalem," 36-7; Smith, To Take Place, 84-8; Stenger, "Eusebius and the Representation of the Holy Land," 382-87; Telfer, Cyril, 43-7; Walker, Holy City, 1-15.
} 
interests might have interpreted Constantine's reforms and the development of Palaestina during the fourth century.

Historians have thoroughly covered many different aspects of Jerusalem and Palaestina in the fourth century, including Constantine and his religious and political reforms, Christian attitudes towards Constantine and his reforms, Eusebius, Cyril and their writings, and, finally, Christian pilgrimages to Palaestina in the fourth century. ${ }^{5}$ Walker's, Holy City, Holy Places?, for example, contrasts Eusebius's views of Palaestina and the city of Jerusalem with those of Cyril and argues that the two bishops were divided by political differences as much as theological ones. My thesis builds upon the strong foundations of the many historians who have already written about fourth-century Jerusalem and Palestine by adding an analysis of the Bordeaux Itinerary to the discussion. Scholars have taken multiple different approaches to understanding the writings of Eusebius, Cyril, and the Bordeaux pilgrim. Historians have looked at the Bordeaux Itinerary in multiple ways to study many different topics. These can range from travel in the Mediterranean world in the fourth century, ${ }^{6}$ geographic map-making and travel itineraries in the Roman Empire, ${ }^{7}$ or even Christian travel narratives and pilgrimages. ${ }^{8}$ In

\footnotetext{
${ }^{5}$ See further: Armstrong, “Constantine's Churches”; Drijvers, Cyril (especially chapter 1); Potter, Constantine (especially chapter 31); Leo P. McCauley, "General Introduction” in The Works of Saint Cyril of Jerusalem. Volume 1. trans. Leo P. McCauley, Fathers of the Church 61 (Washington, D.C.: Catholic University of America Press, 1969), 14-18; Joseph Rivers, "Pattern and Process in Early Christian Pilgrimage" (PhD diss., Duke University, 1983); Schiffman, "Jerusalem"; Smith, To Take Place, 88-91; Stenger, "Eusebius and the Representation of the Holy Land"; Telfer, Cyril of Jerusalem; Walker, Holy City, (especially chapter 1).

${ }^{6}$ John Wilkinson, Egeria's Travels to the Holy Land (Warminster: Aris \& Phillips 1981), 13-14.

${ }^{7}$ Leyerle, "Landscape as Cartography," 119-43.

${ }^{8}$ Glenn Bowman, "Mapping History's Redemption: Eschatology and Topography in the Itinerarium Burdigalense," in Jerusalem: Its Sanctity and Centrality to Judaism, Christianity, and Islam, ed. Lee I. Levine (New York: Continuum, 1999), 167-84; Tom B. Jones, "In the Twilight of Antiquity," The R. S. Hoyt Memorial Lectures, 1973 (Minneapolis: University of Minnesota Press, 1978): 21.
} 
addressing some gaps in the historiography of the itinerary, Douglas argues that what the pilgrim intentionally leaves out of the itinerary can be as enlightening as what is included. Irshai argues that the itinerary helps show how Christians built upon the Jewish history of Judaea to create a Christian Holy Land. ${ }^{9}$ Drijvers believes it is possible that many sites throughout Palaestina only became sacred for Christians because Constantine built churches to honor them. ${ }^{10}$ This thesis analyzes the Bordeaux Itinerary and compares it directly to the writings of Eusebius and Cyril. This thesis provides an analysis of how the Bordeaux pilgrim understood the transformation of the Jewish history of Palaestina into a Christian land filled with both a rich history and powerful miracles. While the Itinerary is relatively brief compared to the writings of both Eusebius and Cyril, it provides historians with a viewpoint of Christians' beliefs towards Palaestina and Jerusalem that cannot be found in either of the bishops' works.

This thesis is structured into three main chapters. The first provides a brief overview of the events and sources necessary to understand the differing Christian attitudes toward Palaestina and Jerusalem in the mid-fourth century. It begins with an overview of Constantine's developments in the Roman province of Palaestina, and specifically the city of Jerusalem, and illustrates how the emperor poured imperial funds into building churches and making the region more attractive to pilgrims. To orient the

\footnotetext{
${ }^{9}$ See further: Laurie Douglas, "A New Look at the Itinerarium Burdigalense," Journal of Early Christian Studies 4.3 (1996); Jas Elsner, "The Itinerarium Burdigalense: Politics and Salvation in the Geography of Constantine's Empire," The Journal of Roman Studies 90 (2000); Irshai, "The Christian Appropriation of Jerusalem." Other scholars address the Bordeaux Itinerary to a lesser degree in their work, usually just mentioning that the itinerary is the earliest surviving Christian itinerary to Jerusalem, including: Drijvers, Cyril; Leyerle, "Landscape as Cartography"; Maraval, "The Earliest Phase of Christian Pilgrimage"; Smith, "My Lord's Native Land"; Rivers, "Pattern and Process"; Walker, Holy City.

${ }^{10}$ Drijvers, Cyril, 15.
} 
reader, the chapter also includes brief biographical sketches of the three major sources examined in this thesis.

The next chapter analyzes how our three sources, Eusebius, Cyril, and the Bordeaux pilgrim, described and interpreted three major basilicas constructed by Constantine as part of his Holy Land project. These churches, the Church of the Nativity in Bethlehem, the Eleona at the Mount of Olives, and the Holy Sepulchre in Jerusalem, formed what modern historians would later call Eusebius's Triad of Churches. ${ }^{11}$ This chapter analyzes how Eusebius worked to develop a narrative around these three churches that focused on their distance from Jerusalem, while Cyril rejected the concept of a triad. He believed the Holy Sepulchre in Jerusalem was the most important church, and all other churches were secondary. ${ }^{12}$ The Bordeaux pilgrim took a very different view of these three churches, and so this chapter considers his pilgrimage to Jerusalem and analyzes how he experienced these churches independent of political connections. As the pilgrim journeyed through Palaestina and Jerusalem, stopping at each of these churches, he saw and experienced their beauty and made note of the historical significance of the locations upon which they were built. There is no sign in the itinerary that the pilgrim even knew about the theological differences that would develop over these basilicas. What is clear from the itinerary, however, is that Constantine was successful at drawing Christian interest towards Palaestina.

\footnotetext{
${ }^{11}$ See, for example, Drijvers, Cyril, 15-21; Walker, Holy City, 184-98. Note also that in Vit. Const. (3.4143) Eusebius treats these three churches in isolation, thus forming, even if never labeling, the triad. ${ }^{12}$ Catech. 13.28; Dayna S. Kalleres, "Cultivating True Sight at the Center of the World: Cyril of Jerusalem and the Lenten Catechumenate 1," Church History 74.3 (2005): 451.
} 
Chapter Four examines how each author understood the broader region of Palaestina and how Jerusalem fit into this worldview. This chapter analyzes three phases of Eusebius' writings to illustrate how his views of Palaestina and Jerusalem changed throughout his life. It starts with his earliest writings, where his views towards Jerusalem were comparatively positive, then shows how Eusebius become critical of Jerusalem, where he argued that the city had been condemned by God and held no value for Christians. The chapter then considers how Eusebius's interactions with Constantine changed his opinions again to admit the land of Palaestina held great significance for Christians, even if this significance was historical in nature. ${ }^{13}$ It then compares Cyril's views with the views of Eusebius. Specifically, it discusses Cyril's belief that Jerusalem, and the rock of Golgotha inside the Holy Sepulchre, was the most important place in the entire world. ${ }^{14}$ Finally, Chapter Four examines the Bordeaux pilgrim's views of the land and analyzes how his structuring of the itinerary reveals the importance of Palaestina in his religious worldview. This chapter also analyzes the pilgrim's shift in focus in the itinerary from primarily Jewish, Old Testament, references in the countryside around Palaestina to a much more Christian, New Testament, focus when in and around Jerusalem. Finally, the chapter shows how the pilgrim's account of Palaestina and Jerusalem reveals that for the pilgrim, Palaestina is a land with a rich history and

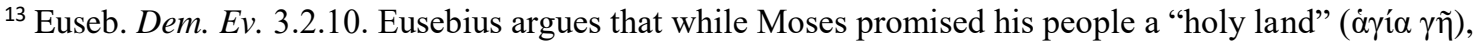

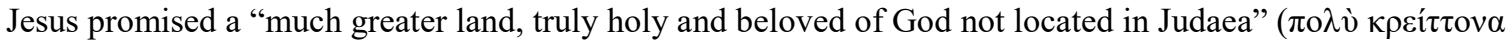

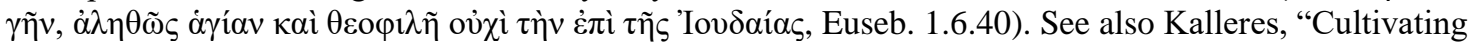
True Sight at the Center of the World," 432; Walker, Holy City, 58-61.

${ }^{14}$ Catech. 13.22; See also Kalleres, "Cultivating True Sight at the Center of the World," 431.
} 
miracles, but the Jewish origins have been incorporated into the Christian redefinition of the land.

This thesis discusses how Christians understood and interpreted Constantine's Holy Land policy. Three particular Christians, each with their own goals and worldviews, have been chosen to illustrate a fuller picture of Christianity in the fourth century. While Eusebius and Cyril help reveal the various opinions of Christians in positions of power from within Palaestina, the Bordeaux pilgrim, an outsider to Palaestina with no known political attachments either way, reveals a third viewpoint of Constantine's developments. Together these sources reveal that Christians were not of one mind about the developing Holy Land. The church fathers were more interested in their own political positions rather than the theological implications of a new Holy Land. The pilgrim, on the other hand, focused on the journey, seeing the most interesting sites and marveling at their beauty; he makes no mention of any political or theological debates. For the pilgrim, the Holy Land was only as interesting as the many individual sites worth visiting. Together these three sources reveal how Christians took a nuanced view of Constantine's developments in the fourth century that cannot be so neatly summarized. 


\section{Chapter 2}

\section{Constantine, the Bishops, and the Pilgrim}

This chapter addresses the background material necessary to understand the history and sources that are developed in more detail in chapters three and four. It begins with a brief historical survey of Palaestina from its incorporation into the Roman Empire in the first century BCE to the time of Constantine's developments of the land in the fourth century. While tracing the emperor's developments of Palaestina and Jerusalem, the chapter discusses how his Holy Land policy transformed the region. The chapter then introduces our three main sources, Eusebius, bishop of Caesarea, Cyril, bishop of Jerusalem, and the Bordeaux pilgrim.

\section{1: Constantine and the Holy Land}

The Roman province of Palaestina was a region with a rich history. Palaestina was added to the Roman Empire under the conquest of the general Pompey the Great in $63 \mathrm{BCE}$. A little more than a century later the Jewish people revolted against Roman rule. In 70, Titus, son of the emperor Vespasian, quelled the Jewish rebellion, laid siege to the capital city of Jerusalem, destroyed the Temple, and left the city in ruins. After six decades of recovery, the region again revolted against Roman oppression. In 135, the emperor Hadrian brutally suppressed the revolt, destroyed much of the city of Jerusalem, and established it as a Roman colony, Aelia Capitolina. Hadrian plowed up to the sacred mount, founded several pagan temples including one to Jupiter and another to Venus on a 
site of religious significance to the locals, and most significantly, banished the Jewish people. $^{15}$

By the third century, Aelia Capitolina was a Romanized city, filled with pagan shrines and cults like those in any other city in the Roman East. Hadrian moved the city and rebuilt a short distance away at less than half the original size of Jerusalem. As historian Jan Drijvers argues, “Aelia Capitolina was a rather insignificant provincial town that did not differ in architectural appearance or religious and administrative character from other towns and cities in the Roman Near East." ${ }^{16}$ Aelia became a garrison city, and many of the soldiers who fought in the rebellions retired there. Administratively, Aelia was organized as a Roman colony, while the province of Palaestina was run from the political center of Caesarea. ${ }^{17}$ Eusebius of Caesarea discusses in his work the Martyrs of Palestine how the Roman governor of Caesarea, Firmilian, while interrogating Christian prisoners, asked them to name their city. When they answered "Jerusalem," which Eusebius notes was a reference to the heavenly Jerusalem, Firmilian did not recognize the name and he concluded that the Christians had secretly founded a city to oppose Rome. ${ }^{18}$ Firmilian's quip, like Hadrian's rebuilding program mentioned above, tended to

\footnotetext{
${ }^{15}$ Drijvers, Cyril, 1-6; Eliav, God's Mountain, 83-86; Holum, "Hadrian and St. Helena," 66; Potter, Constantine, 275-84; Schiffman, "Jerusalem," 36-7; Stenger, "Eusebius and the Representation of the Holy Land," 382-87; Telfer, Cyril of Jerusalem, 43-7; Tsafrir, "Byzantine Jerusalem," 133-35; Wharton, "The Baptistry of the Holy Sepulcher," 321-22; Walker, Holy City, 3-15.

${ }^{16}$ Drijvers, Cyril, 2.

${ }^{17}$ Drijvers, Cyril, 1-3; Eliav, God's Mountain, 83-86; Holum, "Hadrian and St. Helena," 66; Schiffman, "Jerusalem," 36-7; Walker, Holy City, 3-15.

${ }^{18}$ Euseb., Mart. Pal. 11.8-9; see also Drijvers, Cyril, 1-3.
} 
downplay the Jewish history of Jerusalem. In Roman eyes, by the fourth century, the city of Jerusalem had transformed into Aelia Capitolina. ${ }^{19}$

In 324/5 Constantine defeated his political rivals and became the sole emperor in the Roman world. He ended Christian persecution and developed an interest in the city of Jerusalem. ${ }^{20}$ What was once a forgotten city underwent a transformation into a prominent Christian city, filled with the architectural splendor of several major churches and monasteries. Constantine was preoccupied with the desire to unify all of Christendom. He worked to root out heresy and unify the holy literature of the Bible at the Council of Nicaea. Constantine felt particularly compelled to unify the Christian people behind a single holy place. ${ }^{21}$ Eusebius, in his Life of Constantine, describes how the Holy Spirit moved the emperor to take the land of Christ's resurrection and make it "an object of attraction and veneration to all."22 Telfer argues that "Constantine had, in short, a considered Holy Land policy" designed to unite the Church through the development of the Holy Land, particularly in the holy city of Jerusalem. ${ }^{23}$

\footnotetext{
${ }^{19}$ Drijvers, Cyril, 1-28; Eliav, God's Mountain, 83-86; McCauley, The Works of Saint Cyril of Jerusalem, 14-18; Walker, Holy City, 3-15.

${ }^{20}$ Drijvers, Cyril, 174; T. G. Elliott, “Constantine's Conversion: Do We Really Need It?,” Phoenix 4.4 (1987): 421-25; Eliav, God's Mountain, 83-86; Hunt, "Were there Christian Pilgrims before Constantine?," 25-6; Irshai, "The Christian Appropriation of Jerusalem," 465-67; Maraval, "The Earliest Phase of Christian Pilgrimage," 145-49; Smith, "My Lord's Native Land," 1-6.

${ }^{21}$ Brouria Bitton-Ashkelony, "The Attitudes of Church Fathers Towards Pilgrimage to Jerusalem in the Fourth and Fifth Centuries," in Jerusalem: Its Sanctity and Centrality to Judaism, Christianity, and Islam, ed. Lee I. Levine, (New York: Continuum, 1999), 188; Eliav, God's Mountain, 83-86; Schwartz, Imperialism and Jewish Society, 203-14; Smith, To Take Place, 84-8; Telfer, Cyril of Jerusalem, 46-7; Walker, Holy City, 15.

${ }^{22}$ Euseb. Vit. Const. 3.25. See also Drijvers, Cyril, 21; Telfer, Cyril of Jerusalem, 46.

${ }^{23}$ Telfer, Cyril of Jerusalem, 47; see further: Drijvers, Cyril, 174; Eliav, God's Mountain, 123-126; Hunt, "Were there Christian Pilgrims before Constantine?," 25-6; Irshai, "The Christian Appropriation of Jerusalem," 465-7; Maraval, "The Earliest Phase of Christian Pilgrimage," 66-67; Smith, "My Lord's Native Land," 1-6; Walker, Holy City, 15-22. While the above scholars generally agree that Constantine took an active role in the shaping of Palaestina and Jerusalem as the Christian Holy Land, Drake, "The Return of the Holy Sepulchre," 263-37, argues that Constantine was not moved by a religious conversion and the spirit of God to build the Holy Sepulchre, as Eusebius argues, but instead he was petitioned by the
} 
In his account of the Life of Constantine, Eusebius transcribes several of the emperor's letters which historians believe to be authentic. ${ }^{24}$ At multiple times, Constantine refers to the region of Palaestina, and the city of Jerusalem in particular, as “holy places." In one letter, Constantine, while describing his mother-in-law's pilgrimage to Palaestina and the discovery of a pagan temple built upon a site of biblical importance, states: "It is certainly a monstrous evil that the holy sites ( $\tau o \grave{v} \varsigma \dot{\alpha} y i o v \varsigma \tau o ́ \pi o v \varsigma)$ should be marred by sacrilegious abominations." ${ }^{\prime 25}$ The lexical range for the Greek word $\ddot{\alpha} \gamma ı \varsigma$ covers various religious implications, including a temple, sacred, devoted to the gods, and most significantly, it is the same word used in the Greek translation of the Bible to refer to the portion of the Hebrew temple, the Holy of Holies ( $\tau \dot{\alpha} \ddot{\alpha} \gamma l \alpha \tau \tilde{\omega} v \dot{\alpha} \gamma i \dot{i} \omega){ }^{26}$ In a separate letter, Constantine, while discussing the most significant Church he would establish in Jerusalem, the Holy Sepulchre, describes the site as "that sacred place ( $\tau \grave{\nu} v$

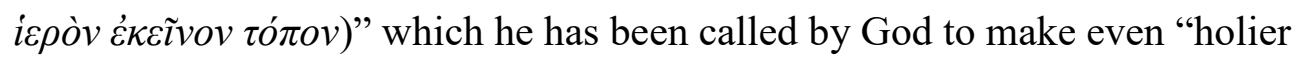
( $\dot{\alpha} \gamma \iota \omega ́ \tau \varepsilon \rho o v) .{ }^{27}$ Here again Constantine confirmed the holiness of the site with his choice

\footnotetext{
fourth-century Christian leaders of Jerusalem, most likely the bishop Macarius, to build the church. Drake argues that the Christians in Jerusalem would have found the site of Jesus's burial and contacted Constantine to start development of the basilica. Drake moves the agency onto the Christian leaders and away from Constantine. Such a view follows the model of a more passive emperor, for which see Fergus Millar, The Emperor in the Roman World, 31 BC-AD 337 (Ithaca, N.Y.: Cornell University Press, 1977). ${ }^{24}$ Potter, Constantine, 145-49; Theodore Cressy Skeat and A. H. M. Jones, "Notes on the Genuineness of the Constantinian Documents in Eusebius's Life of Constantine," The Journal of Ecclesiastical History Vol.5 (1954): 196-201; Harold Allen Drake, In Praise of Constantine: A Historical Study and New Translation of Eusebius's Tricennial Orations (University of California Publications. Classical Studies; v. 15. Berkeley: University of California Press, 1976), 8.

${ }^{25}$ Euseb. Vit. Const. 3.52 (Translation by Averil Cameron and Stuart G. Hall).

${ }^{26}$ Liddell and Scott, s.v. "ó $\gamma l \alpha . "$

${ }^{27}$ Euseb. Vit. Const. 3.30 The entire passage: "The thing therefore which I consider clear to everybody is what I want you in particular to believe, namely that above all else my concern is that that sacred place, which at God's command I have now relieved of the hideous burden of an idol which lay on it like a weight, hallowed from the start by God's decree, and now proved yet holier since it brought to light the pledge of the Saviour's passion should be adorned by us with beautiful buildings," (Translation by Averil Cameron and Stuart G. Hall). See also Drijvers, Cyril, 15-21; Walker, Holy City, 235-41.
} 


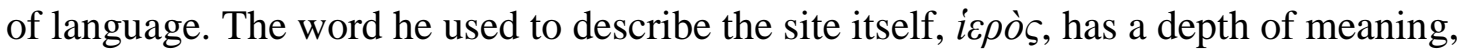
covering sacred, holy, sacrificial, wonderful, and a temple or holy place. ${ }^{28}$ Constantine's word choices demonstrate that he believed, or at least was publicly presenting the view, that Palaestina, and Jerusalem in particular, were holy and that he was called by God to confirm the holiness of this land and focus upon it as the center of the Christian faith. ${ }^{29}$ Maraval argues that Constantine was the first to call Jerusalem the Holy Land, a term that would become common currency throughout the rest of the fourth century for Christians. ${ }^{30}$

Constantine enacted his Holy Land policy to develop Jerusalem as the center of the Christian world. The first building program that he started was to establish a church in Roman Aelia that became the center of the newly developing Christian Jerusalem. For this church, Constantine chose the mount of Golgotha, which Christians considered to be the location of Christ's crucifixion. In order to build his church, the emperor ordered the destruction and removal of the temple to Venus that Hadrian had constructed as a demonstration of Roman authority. ${ }^{31}$ Constantine's Holy Sepulchre would be built so that

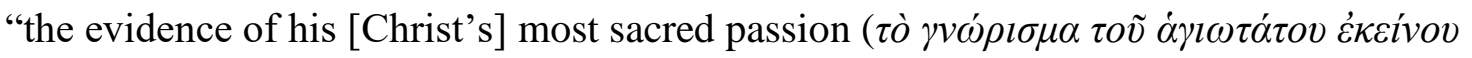
$\pi \dot{\alpha} \theta o v \varsigma)$ might be brought out of the ground and into the light." 32 As the temple to Venus

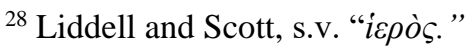

${ }^{29}$ Euseb. Vit. Const. 3.30 quotes Constantine's letter to Macarius, the current bishop of Jerusalem, in which the emperor say that "at God's command" he was removing the pagan temples and shrines from Jerusalem, which acted as "hideous burdens" on the holy land. (Translation by Averil Cameron and Stuart G. Hall). See also Drijvers, Cyril, 15-21; Walker, Holy City, 235-241.

${ }^{30}$ Maraval, "The Earliest Phase of Christian Pilgrimage in the Near East," 67.

${ }^{31}$ Armstrong, "Constantine's Churches," 13-16; Drijvers, Cyril, 13; Holum, "Hadrian and St. Helena," 66; Schiffman, "Jerusalem," 36-7; Smith, To Take Place, 84-8; Stenger, "Eusebius and the Representation of the Holy Land," 382-87; Tsafrir, "Byzantine Jerusalem," 136-39; Walker, Holy City, 6.

${ }^{32}$ Euseb. Vit. Const. 3.30 (Translation by Averil Cameron and Stuart G. Hall). See also Drijvers, Cyril, $15-$ 21; Walker, Holy City, 235-241.
} 
was torn down, and the foundations of Golgotha were unearthed, Christians discovered a cave that they believed to be the cave of Jesus' burial and resurrection. The Holy Sepulchre thus became a site of sacred significance, covering both the site of Jesus' death as well as the resurrection. Finished and consecrated in 335, it was one of the most magnificent churches of its day. The construction of the church was also a political message indicating that Christianity had the full support of the emperor and that Jerusalem was at the center of his new religious policy. With Constantine's work in Jerusalem, more Christians became aware of the rich biblical history within Jerusalem and Christian interests began to grow with the promotion of that past. ${ }^{33}$

In her analysis of the creation of the Holy Land, Smith argues that the Christianization of Jerusalem developed from laying Christian significance on top of Jewish Jerusalem through Christian architectural and liturgical development. Constantine thus helped create the Christian Holy Land by imprinting it on top of the old landscape. Constantine absorbed Jewish and pagan notions of holy places and incorporated them into his new imperial Christianity by choosing to build his churches on sites that were at one point the holy sites to the Jews or the pagans, thus making Palaestina the center for Christians in the Empire. ${ }^{34}$

Palaestina therefore was at the center of momentous change and development in the fourth century under Constantine's Holy Land plan. At the start of the fourth century, Christians were experiencing severe persecution under the pagan Roman Emperors.

\footnotetext{
${ }^{33}$ Drijvers, Cyril, 13-18; Leyerle, "Landscape as Cartography," 119-20; Maraval, "The Earliest Phase of Christian Pilgrimage in the Near East," 63-67; Pullan, "Intermingled Until the End of Time," 389-400; Smith, To Take Place, 84-8; Smith, "My Lord's Native Land," 1-6; Walker, Holy City, 15-22.

${ }^{34}$ Smith, "My Lord's Native Land," 3.
} 
However, Constantine's developments throughout Palaestina turned the region, and Jerusalem in particular, into the spiritual center of the Christian world. This change can be illustrated with the Bordeaux pilgrim and a later fourth-century pilgrim, Egeria, who journeyed to Jerusalem and wondered at the many magnificent buildings and churches that filled the city and noted the city's many liturgical celebrations. Several royal figures also took pilgrimages to Jerusalem in the fourth century, including Constantine's mother, Helena, and mother-in-law, Eutropia. ${ }^{35}$ Cyril, who was bishop of Jerusalem in the fourth century, even mentions the multitude of strangers who traveled from all ends of the world and thronged to the streets of Jerusalem. ${ }^{36}$ The layout of Jerusalem did not change from the Hadrianic Aelia Capitolina. The streets were still colonnaded, and the bathhouses, theaters, circuses, walls, and gates remained. Even Constantine's churches were made in the Roman basilica style. Yet underneath all the furnishings Jerusalem had transformed into a Christian city. ${ }^{37}$

\section{2: Eusebius of Caesarea}

Much of Eusebius' life is shrouded in mystery. He is commonly referred to as Eusebius of Caesarea because he was the bishop of Caesarea Maritima in Palaestina by 313 and held that position for almost twenty-five years. He, however, called himself Eusebius Pamphili, a name he took mid-life to honor his dear teacher, the martyr

\footnotetext{
${ }^{35}$ Euseb. Vit. Const. 3.41-43; 3.51-53. For more information on these pilgrimages, see Holum, "Hadrian and St. Helena," 66; Lenski, "Empresses in the Holy Land," 113-25; Rivers, "Pattern and Process," 181-90; Smith, To Take Place, 88-91.

${ }^{36}$ Catech. 17.16. See also Drijvers, Cyril, 28.

${ }^{37}$ Armstrong, "Constantine's Churches," 13-16; Drijvers, Cyril, 28; Potter, Constantine, 275-84; Stenger, "Eusebius and the Representation of the Holy Land," 382-87; Telfer, Cyril of Jerusalem, 43-47; Walker, Holy City, 15-22.
} 
Pamphilius. ${ }^{38}$ We do not know much about the first forty years of his life including his date of birth, although the early 260s seems likely. ${ }^{39}$ This rough date comes from a section of his Ecclesiastical History where he states that the bishop of Alexandria during his own time was Dionysius. Since we know that Dionysius died in 265, Eusebius must have been born before that date. ${ }^{40}$

Eusebius' writings provide historians a window into the late third- and early fourth-century world. His writings come generally in three stages. The earliest stage was primarily historical in nature. These works include the Chronicle (dated 303), the first seven books of the Ecclesiastical History (dated 303), the Martyrs of Palestine (dated 311), and the Onomasticon (dated 313). Through writing his Ecclesiastical History Eusebius gained the title "father of Church history." Eusebius to shift the focus in his writings to be more apologetic. During this second stage, Eusebius published his Commentaries on Luke (dated sometime after 313), Preparation for the Gospel (written between 314-18), and his Proof of the Gospel (sometime between 318-323). The third and final stage began after Constantine gained sole control of the empire and after his enactment in 324 of many pro-Christian changes across the Roman world. At this time, Eusebius took a more political stance in his writings in order to promote his own view of Christianity. In fact, he wrote some of his most influential works near the end of his life. These include the Theophany (dated 324),

\footnotetext{
${ }^{38}$ Walker, Holy City, 22-31; Wallace-Hadrill, Eusebius of Caesarea, 11-39; Wolf, "Eusebius of Caesarea," 68.

${ }^{39}$ Drake, In Praise of Constantine, 4-5; Walker, Holy City, 22-31; Wallace-Hadrill, Eusebius of Caesarea, 11-39; Wolf, "Eusebius of Caesarea," 68-69.

${ }^{40}$ Euseb. Hist. Eccl. 3.28.3. See also David Sutherland Wallace-Hadrill, Eusebius of Caesarea (London: ARMowbray, 1960), 11.

${ }^{41}$ Cruse, "Introduction," xvi; Drake, "The Return of the Holy Sepulchre," 263.
} 
the final three books of his Ecclesiastical History (dated $325 \mathrm{CE}$ ), his speech On Christ's Sepulchre (dated 335), the oration In Praise of Constantine (dated 336), and finally his Life of Constantine (dated 336). ${ }^{42}$

Eusebius was a vocal supporter of Constantine and he took Constantine's interest in the Holy Land to heart. He wrote a great deal of geographical material to put the Holy Land on the religious map. These works include the first two books of Eusebius' Ecclesiastical History, which detailed important geographical locations to Church history and the history of the Martyrs of Palestine. However, the Onomasticon, Eusebius's geographical survey of Palaestina, was his most influential work in transforming the Christian mental map of the Holy Land. The Onomasticon functioned as an encyclopedic list of place names found in the Bible, with certain limitations. For example, only places within Palaestina itself were listed, this excluded many of the cities to which Paul traveled and founded churches. This element alone shows that the Onomasticon was not a geographic overview of the entire holy scripture, rather it was much more interested in the Holy Land Constantine was creating. ${ }^{43}$ Written in Greek, the volume is arranged in alphabetical order. Within each sorted letter of the alphabet, the names are arranged by book of the Christian Bible, starting with the Old Testament book of Genesis. ${ }^{44}$ In total, there are almost 1,000 names, most of which come from the Old Testament.

\footnotetext{
${ }^{42}$ Walker, Holy City, 23-26; Wallace-Hadrill, Eusebius of Caesarea, 57-58. See also Walker's Appendix. Note that the dates of composition are not accepted by every scholar. See also Averil Cameron and Stuart George Hall, "Introduction," in Eusebius, Life of Constantine, trans. Averil Cameron and Stuart George Hall (Oxford: Oxford University Press, 1999), 1-2, and Wallace-Hadrill, Eusebius of Caesarea, 11-13.

${ }^{43}$ Rivers, "Pattern and Process," 157-63; Stenger, "Eusebius and the Representation of the Holy Land," 385-96; Walker, Holy City, 24, 42, 71; Wolf, "Eusebius of Caesarea," 74.

${ }^{44}$ Wolf, "Eusebius of Caesarea," 74; Stenger, "Eusebius and the Representation of the Holy Land," 386-87.
} 
In his Onomasticon, Eusebius provides his readers with several aids for understanding the geography and history of Palaestina. First, he transcribed the Hebrew names in the Old Testament into Greek. Second, Eusebius provided a geographical description of Judea, especially dealing with the division of the land according to the twelve tribes. Finally, he offered a plan of ancient Jerusalem and the temple. ${ }^{45}$ As Stenger argues, Eusebius' main concern was not to provide complete and detailed coverage of a geographical region, but rather to portray Palaestina as a place that had a concrete significance for his intended Christian audience. ${ }^{46}$

Much of Eusebius's interests in the geography of Palaestina came from his position as bishop of Caesarea, the region's political capital. Being bishop gave Eusebius significant power and authority and he had many reasons to support Constantine and his building programs. With the money and attention the emperor was making available, the region was gaining authority in religious matters. As the bishop of the provincial capital, he was preferred in authority and honor over all other bishops in the province. Yet there was a problem.

The seventh canon of the Council of Nicaea (325) introduced some tensions between Caesarea and Jerusalem. On one hand, the canon stated that the bishop of Jerusalem was the most prominent bishop, only below the bishops of Rome, Alexandria,

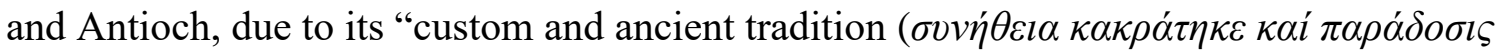
$\dot{\alpha} \rho \chi \alpha i \alpha) . "$ This statement clearly gave Jerusalem religious authority on the same level as

\footnotetext{
45 Rivers, "Pattern and Process," 157-63; Stenger, "Eusebius and the Representation of the Holy Land," 385; Walker, Holy City, 24, 42, 71; Wolf, "Eusebius of Caesarea," 74.

46 Stenger, "Eusebius and the Representation of the Holy Land," 396.
} 
the most important cities in the Roman world. However, in the same sentence the canon states that the bishop of Jerusalem must be submissive to "the dignity proper to the

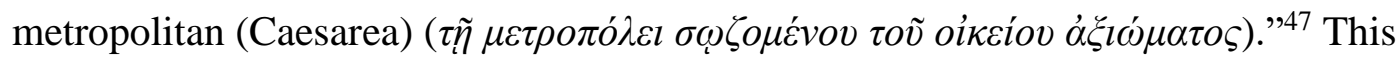
statement from the council created a paradox for Jerusalem and Caesarea. The bishop of Jerusalem was given authority on the same level with the most prominent sees in the world, but it was still subordinate to Caesarea, which, according to the council of Nicaea, was technically lower than Jerusalem. This paradox became a major point of tension for the bishops of Caesarea and Jerusalem as they both desired to hold primacy in Palaestina, a region that was gaining more prominence under Constantine. Eusebius wanted to develop this authority while at the same time keeping Caesarea, where he held the position as the Metropolitan, the political center of Palaestina. ${ }^{48}$

Constantine's Holy Land policy put Eusebius in a delicate position. While much of the region benefited from the many imperial developments, Constantine's focus on Jerusalem, the site of Jesus' death and resurrection, meant it was in a prime position to transition into the new center of the region. With his own position and prestige at risk, Eusebius had to take a careful approach in his writings. As Palaestina grew in prominence, so too did Eusebius' position as the metropolitan. However, Eusebius had to try to shift attentions away from Jerusalem, since it was receiving the majority of imperial attention, which jeopardized his position. In response, Eusebius argued that

\footnotetext{
${ }^{47}$ Drijvers, Cyril, 35-36; Kalleres, "Cultivating True Sight at the Center of the World," 431-36; McCauley, The Works of Saint Cyril of Jerusalem, 1-23; Smith, To Take Place, 77-8; Walker, Holy City, 54-57.

${ }^{48}$ Drijvers, Cyril, 19-36; Kalleres, "Cultivating True Sight at the Center of the World," 431-36; McCauley, The Works of Saint Cyril of Jerusalem, 1-23; Zeev Rubin, "The Cult of the Holy Places and Christian Politics in Byzantine Jerusalem," in Jerusalem: Its Sanctity and Centrality to Judaism, Christianity, and Islam, ed. Lee I. Levine (New York: Continuum, 1999), 151-53; Telfer, Cyril of Jerusalem, 19-20; Walker, Holy City, 22-40.
} 
Jerusalem held no religious significance for Christians because it was the city that rejected Christ and received God's judgment in 70 when Titus sacked and burnt the city. The destruction of Jerusalem and its rededication as a Roman colony was a clear sign that God had condemned the city. However, In Eusebius's view, the region of Palaestina held great historical significance for Christians because of its rich biblical history. While Palaestina and Jerusalem no longer held any spiritual significance for Christians, the history of the land made it worth development. ${ }^{49}$

Constantine's reforms heavily influenced Eusebius. He wrote the biography, The Life of Constantine and remained in high regards with Constantine as a close advisor from as early as $313 .{ }^{50}$ As the official biographer of the emperor, Eusebius used his proximity to Constantine to help shape imperial attitudes towards Palaestina. Specifically, he used his position to influence Constantine's view of Jerusalem. As Walker argues, Eusebius used what few opportunities he had in the presence of the emperor to shape Constantine's thoughts toward his own. ${ }^{51}$ Indeed, he appears to have adjusted his language to accommodate his intended audience and tailored his arguments to gain maximum effect. ${ }^{52}$ As a result, Eusebius' own writings reveal his view of the importance of Palaestina to the Roman Empire.

\footnotetext{
${ }^{49}$ Drijvers, Cyril, 19-30; Eliav, God's Mountain, 135-140; Walker, Holy City, 20-25. See also Eusebius, Dem. Ev. 3.2.10 for an example of the argument that God's judgment on Jerusalem shows that it had no value over the rest of the earth.

${ }^{50}$ Wolf, "Eusebius of Caesarea," 66-69; Wallace-Hadrill, Eusebius of Caesarea, 19-38.

${ }^{51}$ Cameron and Hall, "Introduction," 1-2; Drijvers, Cyril, 19-30; Walker, Holy City, 29.

${ }^{52}$ Drake, In Praise of Constantine, 46.
} 


\section{3: Cyril of Jerusalem}

Cyril, like Eusebius, was a man whose early life remains largely hidden to historians. He was probably born around 315, although exactly where remains a mystery ${ }^{53}$ While some historians think that he was born in Caesarea, and eventually relocated to Jerusalem, others argue that his knowledge about the topography around Jerusalem and his pro-Jerusalem political leanings make it more likely that he was native of the city or its surrounding area. ${ }^{54} \mathrm{We}$ know he had at least one sister, ${ }^{55}$ and that his rhetorical skills make it more than likely that he received a thorough classical education and that his parents most likely belonged to the educated class of the provincial society in Palaestina. By 350, Cyril was bishop of Jerusalem. ${ }^{56}$ Except for his very early childhood, Cyril lived in a Roman Empire controlled by an emperor who supported Christianity. Unlike Eusebius, Cyril did not experience the types of persecution that many Christians underwent before Constantine gained power. ${ }^{57}$

The surviving sources, Cyril's Catechetical Lectures, are rhetorical and less scholarly in nature than most of Eusebius' work. These eighteen lectures were designed to aid and prepare the catechumenes, the people who decided to join the church through baptism during Easter, in 350, the first year of Cyril's bishopric. These lectures were not

\footnotetext{
${ }^{53}$ See also Drijvers, Cyril, 31; Walker, Holy City, 31-34. This date is based on a passage from Jerome (De Vir. Ill. 112).

${ }^{54}$ Drijvers, Cyril, 31; Walker, Holy City, 32-33. Telfer (Cyril of Jerusalem, 19-20), however, argues that Cyril was born in Caesarea.

${ }^{55}$ Epiphanius of Salamis (born around 310 and died in 403) wrote in his Panarion (Pan. 73.37.5) that Gelasius, the bishop of Caesarea between 367-373, was the son of Cyril's sister; see also Drijvers, Cyril, 31.

${ }^{56}$ Drijvers, Cyril, 31; Telfer, Cyril of Jerusalem, 19-20; Walker, Holy City, 31-34.

${ }^{57}$ Eusebius discussed Christian persecution under the Roman Empire at various points in his earliest writings. Most significantly, his Martyrs of Palestine was dedicated to preserving the history of the many Christians who died under the Diocletian persecution in the late third and early fourth-century.
} 
sermons or homilies, but instructions on the fundamentals of the Christian faith and creed, and as such, they covered all the material Cyril believed necessary for new Christians to know as they entered the church. ${ }^{58}$ Cyril never wrote his lectures down. Instead, according to a scribal note in the earliest manuscripts, they were preserved because several monks or nuns transcribed them in shorthand as Cyril delivered them. ${ }^{59}$ A later scribal note states that the lectures were secret and to be kept private, available only to the baptized and "those to be enlightened" ( $\varphi \omega \tau \iota \zeta o$ $\mu \varepsilon v o l) .{ }^{60}$ However, according to Jerome, a late fourth, early fifth-century Christian historian, they were in public circulation by the end of the century. ${ }^{61}$

Cyril was not a leading church figure in his day. He published few works and did not play an active role in the many theological debates in his time. According to McCauley, ancient Christian theologians and historians overlooked his lectures as basic theology targeting an inexperienced audience. McCauley argues that the references we have to Cyril in the ancient sources were few, brief, and obscure. ${ }^{62}$ However, from a historical perspective, there is a great wealth of information that can be gained through his lectures.

Cyril worked to promote Jerusalem as a central religious location for the newly developing Christian world. He was the bishop of Jerusalem in 350, little more than two decades after Constantine began his work developing Palaestina. Many of the

\footnotetext{
${ }^{58}$ Drijvers, Cyril, 53; Kalleres, "Cultivating True Sight at the Center of the World," 431-33; McCauley, The Works of Saint Cyril of Jerusalem, 1-2; Walker, Holy City, 31-34.

${ }^{59}$ McCauley, The Works of Saint Cyril of Jerusalem, 1-4.

${ }^{60}$ McCauley, The Works of Saint Cyril of Jerusalem, 1-2.

${ }^{61}$ Jer. De Vir. Ill. 112; see also McCauley, The Works of Saint Cyril of Jerusalem, 1-4.

62 McCauley, The Works of Saint Cyril of Jerusalem, 12-13.
} 
developments of Palaestina were still ongoing during his time. These lectures then provide historians with an important picture of Christian Jerusalem and how Christian "holy places" developed throughout the mid-fourth century. Cyril, as compared to Eusebius, was not driven by a love of history. As the bishop of Jerusalem, Cyril was much more invested in establishing Jerusalem as the central city for the developing Christian Empire, and therefore his lectures present a more positive view of Jerusalem than those found in any of Eusebius' writings. ${ }^{63}$

Tension with Caesarea dominated Cyril's time as bishop of Jerusalem, from 350 to 386 . The problems between the two most powerful sees of Palaestina concerned the authority of the church province. As we noted above, the two cities rivaled one another for political and religious authority in Palaestina. While Eusebius responded to the seventh canon of Nicaea by downplaying the significance of Jerusalem in his writings, Cyril took the opposite approach. Throughout the Catechetical Lectures, he espouses the prestige and status of Jerusalem. He not only wanted Jerusalem, because of its rich biblical history, to be the most important city in the Christian world, he wanted it to be the most authoritative bishopric in Palaestina. ${ }^{64}$ This desire put a great deal of strain between Cyril and Acacius, the bishop of Caesarea between 341-365. Acacius used his position to bring various charges of misappropriation of church funds against Cyril and ultimately had him removed as bishop. Cyril appealed the case to Emperor Constantius II

\footnotetext{
${ }^{63}$ Bitton-Ashkelony, "The Attitudes of Church Fathers," 199; Drijvers, Cyril, 31-63; Kalleres, "Cultivating True Sight at the Center of the World," 431-433; McCauley, The Works of Saint Cyril of Jerusalem, 1-23; Rubin, "The Cult of the Holy Places," 153-7; Walker, Holy City, 33. ${ }^{64}$ Drijvers, Cyril, 35-38; Kalleres, "Cultivating True Sight at the Center of the World," 431-436; McCauley, The Works of Saint Cyril of Jerusalem, 1-23; Walker, Holy City, 36-40.
} 
and was reinstated. Throughout the course of his career, Cyril would be removed and reinstated as bishop of Jerusalem three times. In 357 (reinstated in 359); in 360 (reinstated in 361); and finally in 367 (reinstated in 376). After the third reinstatement, Cyril held the position of bishop of Jerusalem undisputed until his death in $386 .{ }^{65}$

Eusebius was born around 260 and Cyril around 315, two generations apart. By the time Constantine came to power in the East in 324, Eusebius was in his mid-sixties and Cyril was about ten years old. Yet there is a surprisingly small gap between the writings of these two Christians fathers. Eusebius was an active writer into his eighties and Cyril began his public life early. The most important published works which discussed Constantine's developments within Palaestina were separated by little more than a decade. As Walker argues, "these two men would, more than any others, determine the nature of Christian Palaestina and thereby affect in many ways the subsequent life of the whole Church." 66 Eusebius and Cyril differed on many significant issues concerning the degree to which Palaestina should be considered a "Holy Land" and how Christians should handle the many different "holy places" of Christ. So, while these two bishops provide a window into the changes Palaestina was undergoing under Constantine, another source, the so-called Bordeaux pilgrim, offers us a very different viewpoint.

\section{4: The Bordeaux Itinerary}

The Bordeaux Itinerary (Itinerarium Burdigalense) is the earliest surviving Christian travel itinerary to the Holy Land. Dated to 333, the pilgrim wrote it a little more

${ }^{65}$ For more on Cyril's appointments and removals, see Drijvers, Cyril, 35-44.

${ }^{66}$ Walker, Holy City, 21. 
than a decade after Constantine began his transformation of the region. ${ }^{67}$ As Douglass explains, the entire travel narrative covers roughly twenty-six pages in the manuscript, 672 lines, and chronicles the trip between Bordeaux in southern France to Jerusalem and then back through Rome to Milan. ${ }^{68}$ The itinerary has three distinct sections. The first twelve-page section, 372 lines, is not very different from other ancient travel narratives. ${ }^{69}$ As in the example below, it consists of a list of places, the distances between those places, usually in Roman miles, and a single word description of the type of stop that was made between these locations, either to change a horse (mutatio), a temporary rest stop (mansio), or a more comfortable stop in a city (civitas). ${ }^{70}$

\section{Bordeaux Itinerary (558.3-559.13):}

Change (mutatio) at Argentea:

Change (mutatio) at Pons Aureolus:

City (civitas) of Bergamum:

Change (mutatio) at Tellegate:

Change (mutatio) at Tetellus:

City (civitas) of Brixa:

Halt (mansio) at Felexus:

Change (mutatio) at Beneventum:

City (civitas) of Verona:

Change (mutatio) at Cadianum:

Change (mutatio) at Aurei:

City (civitas) of Vincentia:

Change (mutatio) at the frontier:

City (civitas) of Patavium:

Change (mutatio) at the twelfth milestone:

Change (mutatio) at the ninth milestone:
10 miles

10 miles

13 miles

13 miles

10 miles

10 miles

11 miles

10 miles

10 miles

10 miles

10 miles

11 miles

11 miles

10 miles

12 miles

11 miles

${ }^{67}$ It. Burg, 571.6-8: "We traveled in the consulate of Dalmatius and Zenophilius, leaving Chalcedonia on 30 May and returned to Constantinople on 26 December in the same consulate."

68 Douglas, "A New Look at the Itinerarium Burdigalense" 313.

${ }^{69}$ J. A. Talbert, "Author, Audience and the Roman Empire in the Antonine Itinerary," in Herrschen und Verwalten: Der Alltag der romischen Administration in der hohen Kaiserzeit, 256-70.

${ }^{70}$ Douglas, "A New Look at the Itinerarium Burdigalense" 313-16; Elsner, "The Itinerarium Burdigalense,"187; Irshai, "The Christian Appropriation of Jerusalem," 471; Blake Leyerle, "Landscape as Cartography," Journal of the American Academy of Religion 64.1 (1995): 121-126; Smith, "My Lord's Native Land," 11-12. 
City (civitas) of Altinus:

9 miles

Change (mutatio) at Sanus:

10 miles

City (civitas) of Concordia:

9 miles

Change (mutatio) at Apicilia:

9 miles

Change (mutatio) at the eleventh milestone:

11 miles

City (civitas) of Aquileia:

Total from Milan to Aquileia: 251 miles, 24 changes, 9 halts $^{71}$

11 miles

The Bordeaux Itinerary travel narrative takes a dramatic shift in the second

section when the pilgrim arrives in Palaestina. For the next eight pages, 123 lines, instead of a simple travel narrative, the itinerary shifts focus to become much more descriptive as the author appears keen to map territory onto scriptural events. In this section, the pilgrim provides a colorful, touristic, pilgrim-centered account of the important biblical events throughout Palaestina and the Holy Land. ${ }^{72}$ For example, shortly into Palaestina, the pilgrim mentions: "Here is the almond tree; here Jacob saw the vision and the angel wrestled with him." ${ }^{.73}$ The final six-page section (177 lines) is similar to the first section, chronicling the return journey traveling through Rome and ending in Milan. According to Drijvers, the account of the pilgrim illustrates the degree to which Jerusalem had changed in the few years following the implementation of Constantine's building program. ${ }^{74}$

Historians do not know the identity of the Bordeaux pilgrim. No record of the pilgrim's name or any significant biographical material survives. Some details within the itinerary itself have led one scholar to suggest the pilgrim might have been a woman, but

\footnotetext{
${ }^{71}$ It. Burg., 558.3-559.13.

72 Douglas, "A New Look at the Itinerarium Burdigalense," 313-16; Elsner, "The Itinerarium Burdigalense," 183-85; Irshai, "The Christian Appropriation of Jerusalem," 471; Leyerle, "Landscape as Cartography," 121-26; Smith, "My Lord's Native Land," 11-12.

${ }^{73}$ It. Burg., 588.9-10.

${ }^{74}$ Drijvers, Cyril, 12.
} 
the evidence is ambiguous enough to leave us uncertain. ${ }^{75}$ All we have is the itinerary itself, which, fortunately, provides a significantly different approach to the discussion of Palaestina and Jerusalem than that provided by the bishops. The itinerary is not a sermon, letter, or lecture, but a travel log that chronicled one person's experience of the Holy Land. The nameless pilgrim was most likely not a highly-educated church leader. There are no known accounts of any significant church figure taking a pilgrimage to Jerusalem from France at that time. The fact that the pilgrim remains unidentified also supports the fact that this was not a well-known figure. He was also not familiar with the region he was visiting since he claims to have relied upon tour-guides to show him around Jerusalem and to point out significant sites like the great churches and basilicas that Constantine was building at that time. ${ }^{76}$ According to Rivers these guides likely came from the indigenous communities. ${ }^{77}$ Most important, however, is that the pilgrim was not educated in Church history. When the pilgrim reaches the site of the Eleona, on the Mount of Olives, the site of Christ's ascension into heaven, according to the book of Acts 1:6-11, he mistakes the site for another biblical event on a mountain, the transfiguration, a point that will be further developed in chapter $3.3 .^{78}$ The pilgrim was clearly unfamiliar with the biblical history of the Mount of Olives and was either misinformed by a guide about the history of this mountain, did not ask about the history of the mountain, or simply did not care to learn. In any case, this mistake demonstrates that the biblical

\footnotetext{
75 Douglas, "A New Look at the Itinerarium Burdigalense" 314; Irshai, "The Christian Appropriation of Jerusalem," 469-71; Rivers, "Pattern and Process," 179-81.

${ }^{76}$ It. Burg., 594.2, 595.6, 599.6.

77 Rivers, "Pattern and Process," 178-81.

${ }^{78}$ It. Burg., 595.6; Walker, Holy City, 213-4.
} 
history of the Church of the Eleona on the Mount of Olives was much less significant to the pilgrim than it was to either Eusebius or Cyril. As we will discuss in chapter 3.2, both church fathers spent a significant amount of time discussing the theological significance of the Mount of Olives and the church that Constantine built.

The pilgrim was not a Christian leader, but an anonymous Christian taking a personal journey from France to Jerusalem to experience the history and wonder of Constantine's new Holy Land. His account provides historians with a very different viewpoint to understand how Christians understood the changes in Palaestina and Jerusalem in the fourth century. The pilgrim was an outsider, not a native of the region like Eusebius and Cyril, and the pilgrim offers an on-the-ground perspective, traveling through Palaestina, not from the top, preaching from the position of bishop. While the pilgrim might not be educated on the significance of these many biblical events, the very fact that he chose to journey across the Roman Empire to visit Jerusalem shows the impact of Constantine's Holy Land policy.

Eusebius and Cyril both had very strong opinions, shaped by their theological and political views, on what position Jerusalem should take within Palaestina. While these two church leaders spent a great deal of their attention and writings focusing on this issue, for the Christian on the ground, the theological disputes were less important than the experience of journeying through the land Jesus called home. The Bordeaux pilgrim traveled across the Roman Empire to tour the sites of biblical significance. At no point in the pilgrim's travelogue is there any mention of the great theological differences between the various church leaders. To the Bordeaux pilgrim, walking through Jerusalem, the beautiful churches Constantine was building on sites of great biblical history were much 
more important than theological arguments. These three sources provide us with a more nuanced view of Christian attitudes towards Palestine in the fourth century. While Eusebius and Cyril presented their political views to defend their positions as bishops, the pilgrim was more interested in seeing the most important sites throughout the Holy Land. 


\section{Chapter 3}

\section{The Triad of Churches}

The previous chapter discussed the events and sources that are critical to our understanding of changing Christian attitudes toward Palaestina and Jerusalem in the mid-fourth century. Constantine used his imperial funds to develop the Roman province, and the city of Jerusalem in particular. He built churches and made the region more attractive to pilgrims. This development started the change that eventually transformed the region into the Christian Holy Land over the next few centuries. Eusebius, the bishop of Caesarea in the early to mid-fourth century, was resistant to the developing position of Jerusalem, as it threatened his personal power in Caesarea. A decade later, Cyril, bishop of Jerusalem, would endorse a pro-Jerusalem policy in his lectures and writings. The Bordeaux pilgrim, who was most likely not a Church leader, nor someone with any political connections to either city, provides us with a third point of reference to illuminate how Christians might have interpreted Constantine's reforms and the development of Palaestina during the fourth century. This chapter analyzes how these three sources portray Constantine's three significant churches in and around Jerusalem, the Church of the Nativity in Bethlehem, the Eleona church at the Mount of Olives, and finally the Holy Sepulchre in Jerusalem.

Together, these three churches create what modern historians have called the "Triad of churches." 79 Eusebius argued that together these three churches created a fitting summary of Christian belief. In an extended account of the Life of Constantine, Eusebius

\footnotetext{
${ }^{79}$ Drijvers, Cyril, 15-21; Walker, Holy City, 184-98.
} 
described how Constantine, with the help of his mother Helena, founded the three churches. The churches fit thematically together as an overview of the entire narrative of Christ's redemption. The Church of the Nativity represents the first theophany $(\pi \rho \omega \dot{\tau} \eta$ $\theta \varepsilon o \varphi \alpha ́ v \varepsilon l \alpha)$ of Christ's birth; the Holy Sepulchre shows the great struggle ( $\dot{\alpha} \gamma \tilde{\omega} v)$ of

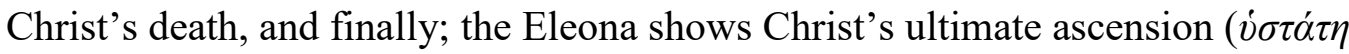
$\dot{\alpha} v \alpha \lambda \dot{\eta} \psi l \varsigma)$ into heaven. ${ }^{80}$ These churches, therefore, symbolized the beginning, middle, and end of Christ's redemption. While Eusebius never directly references the churches as the "Triad," he was the first to connect these three churches together into a unified narrative, and his views on the churches heavily reflected his attitude towards Jerusalem.

One of the key benefits of linking these three churches together to create a Christian narrative was to draw Christian interests outside of Jerusalem. Two of the churches were outside of the walls of Jerusalem, and Eusebius worked to distance the Triad from the city as much as possible. Eusebius could not avoid the fact that the Holy Sepulchre, the most lavish and significant of the three churches, was located within the walls of Jerusalem. However, he could draw attention away from Jerusalem by emphasizing the Christian narrative throughout Palaestina. Whenever Eusebius had to refer to the churches, he did his best to avoid mentioning Jerusalem. As Walker noticed, when the situation required reference to the city as the center of the Triad, he always referred to the Holy Sepulchre, and not the city itself. ${ }^{81}$

Cyril also recognized the significance of the three churches Constantine founded in Palaestina in the fourth century. Like Eusebius, Cyril connected the significance of the

${ }^{80}$ Euseb. Vit. Const. 3.25-43; see also Walker, Holy City, 187.

${ }^{81}$ Walker, Holy City, 193. 
three churches to create a single narrative. In one passage of his Catechetical Lectures, Cyril relates the significance of Christ's descent from heaven into the manger at Bethlehem, his death and resurrection on Golgotha, the site of the Holy Sepulchre, and finally his ascension into heaven at the Mount of Olives. ${ }^{82}$ However, he did not follow Eusebius's desire to link the three churches with the broader region of Palaestina. Instead, Cyril argued the three churches of the Triad were explicitly part of the heritage of Jerusalem and together worked to create a Christian Jerusalem. In other words, he claimed both Bethlehem and the Mount of Olives as part of Jerusalem. ${ }^{83}$

As noted above, the pilgrim's account does not focus on theological or political motivations behind the churches. Instead, the itinerary shows what a single, ground level, Christian thought about these churches and why they were significant to him. ${ }^{84}$ This chapter is organized into three sections. The first section briefly outlines the historical and geographic significance of the three Churches in Eusebius's Triad. The second explains how Eusebius and Cyril understood and interpreted these three Churches. The final section describes how the Bordeaux pilgrim's account of the Triad differed from the opinions of Eusebius and Cyril.

\section{1: The Archaeology of the Triad}

After Constantine became sole emperor in 324, he worked to consolidate his power. One of the ways he did this was through the development of Palaestina to unify

\footnotetext{
${ }^{82}$ Catech. 14.23; see also Walker, Holy City, 195.

${ }^{83}$ In Catech. 12.1 and 14.23 Cyril claims that the Mount of Olives is part of Jerusalem. In Catech. 16.4 Cyril claims Bethlehem is also part of Jerusalem. Speaking within Jerusalem, Cyril argues that Jesus

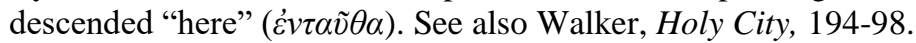

${ }^{84}$ Walker, Holy City, 213. My work thus relies and builds upon Walker's contribution.
} 
the Christian church. Many fourth-century Christians had lived through state sponsored persecution and as a result gained spiritual inspiration through the honoring of the sites and remains of the many Christian martyrs. Constantine desired to repair growing rifts and instability in the ecclesiastical network of his time by elaborating the growing cult practices around tombs and relics of the martyrs in order to assert continuity within the early Christian church. He quickly started development of four churches in Palaestina. Three of the churches were built to honor the momentous events of the life of Christ, which Eusebius would symbolically link together in his narrative of Christ's redemption. The fourth church was built to honor the theophany of Abraham in the old testament and was dedicated at the site near Hebron (about nineteen miles south of Jeruslaem) where he had met three angels sent from God. ${ }^{85}$ While Eusebius discussed the discovery of this church, known as the Mamre, it did not commemorate an event from the life of Jesus, and therefore it did not fit into the Christian narrative he was creating. Consequently, he did not value it nearly as much as Constantine's other churches, the Holy Sepulchre in Jerusalem, the Church of the Nativity in Bethlehem, and the Eleona at the Mount of Olives. ${ }^{86}$

\footnotetext{
${ }^{85}$ Armstrong, "Constantine's Churches," 13-16; Bitton-Ashkelony, "The Attitudes of Church Fathers," 188-89; Bowman, "Mapping History's Redemption," 163-67; Crowfoot, Early Churches in Palestine, 9-15; Drake, "The Return of the Holy Sepulchre," 263-67; Drijvers, Cyril, 11-21; Eliav, God's Mountain, 123-26; Holum, "Hadrian and St. Helena," 66; Lenski, "Empresses in the Holy Land," 113-25; Jodi Magness, The Archaeology of the Holy Land: From the Destruction of Solomon's Temple to the Muslim Conquest (New York: Cambridge University Press, 2013), 323-27; Potter, Constantine, 207-14; Schiffman, "Jerusalem," 36-7; Smith, To Take Place, 77-80; Stenger, "Eusebius and the Representation of the Holy Land," 382-7; Telfer, Cyril of Jerusalem, 43-7; Yoram Tsafrir, Ancient Churches Revealed (Jerusalem: Israel Exploration Society, 1993), 2-11; Tsafrir, "Byzantine Jerusalem," 133-39; Wharton, "The Baptistry of the Holy Sepulcher," 313-21; Walker, Holy City, 171-84; John Wilkinson, "Constantinian Churches in Palestine," in Ancient Churches Revealed, ed. by Toram Tsafrir (Jerusalem: Israel Exploration Society, 1993), 24-27. ${ }^{86}$ Euseb. Vit. Const. 3.51-53; Armstrong, "Constantine's Churches," 5-16; Drijvers, Cyril, 21, 98, 118; Holum, "Hadrian and St. Helena," 70; Lenski, "Empresses in the Holy Land," 113-25; Tsafrir, Ancient Churches Revealed, 2-6; Walker, Holy City, 17.
} 
According to Eusebius, Constantine dedicated the Holy Sepulchre first. He did so to commemorate Christ's death and resurrection, and it was the most significant of all Constantine's basilicas. Throughout the fourth century, Christians of all persuasions came to acknowledge their common origins in the death and resurrection of Jesus Christ. ${ }^{87}$ According to Eusebius, even as early as the second century, Christians believed the location of Christ's death and resurrection was a holy site, one worth honoring. It was for this reason that when Hadrian destroyed the city of Jerusalem in 135, he took special interest to cover the site with a temple to Venus. ${ }^{88}$

According to Eusebius, Constantine ordered the destruction of the temple to Venus, and later construction of the Holy Sepulchre, between 325/326. Shortly after the discovery of the rock of Golgotha and the tomb of Christ, the empress Helena took a pilgrimage to Palaestina in 325 to inspect, with imperial concern, the land on which Jesus walked. During this pilgrimage, Helena dedicated the two remaining churches in Eusebius's Triad. In this way, the dedication of all three churches in the Triad were started around 325. Constantine put significant effort into these churches, and it took the better part of a decade to finish their construction. Both the Church of the Nativity and the Eleona were finished in 333, around the time of the Bordeaux pilgrim's pilgrimage to Jerusalem. However, the Holy Sepulchre took longer to build. Eusebius gave his speech,

${ }^{87}$ Bitton-Ashkelony, "The Attitudes of Church Fathers," 188-89; Bowman, "Mapping History’s Redemption," 163-67; Smith, To Take Place, 77-80; Tsafrir, Ancient Churches Revealed, 2-11.

${ }^{88}$ Euseb. Vit. Const. 3.26; see also Armstrong, "Constantine's Churches," 13-16; Bitton-Ashkelony, "The Attitudes of Church Fathers," 188-89; Bowman, "Mapping History's Redemption," 163-67; Crowfoot,

Early Churches in Palestine, 9-15; Drake, "The Return of the Holy Sepulchre," 263; Drijvers, Cyril, 11-21; Eliav, God's Mountain, 123-26; Stenger, "Eusebius and the Representation of the Holy Land," 382-87; Telfer, Cyril of Jerusalem, 43-7; Tsafrir, "Byzantine Jerusalem," 133-39; Wharton, "The Baptistry of the Holy Sepulcher,” 321; Walker, Holy City, 171-84. 
On Christ's Sepulchre, at the consecration of the church in 335, two years after the pilgrimage of the Bordeaux pilgrim. ${ }^{89}$

In his archaeological survey of ancient churches, Tsafrir shows that Palaestina was remarkable for the number of holy sites that where either connected to biblical tradition or the life of Jesus. ${ }^{90}$ This density of holy sites led to the creation of many commemorative churches, or martyria. The martyria was a special type of church that was designed for commemorative purposes. This style of church was centered around a large round, octagonal, square, or cruciform room that could allow a greater number of people to see the relic or tomb at the center. This church design also drew heavy inspiration from the Roman-style temples, like the Pantheon or the monumental tombs of emperors and patriarchs of Rome. The Constantinian churches drew inspiration from both the basilica and the martyria. These churches prominently featured a basilica at the entrance. This was a large, open, room which functioned as a public meeting space. However, instead of focusing on the apse like the traditional basilica style, Constantinian churches were designed around the geometric center of the building, the martyria, which

\footnotetext{
${ }^{89}$ Euseb. Sep. Chr.; See also Armstrong, "Constantine's Churches," 13-16; Crowfoot, Early Churches in Palestine, 9-15; Drake, "The Return of the Holy Sepulchre," 263-67; Holum, "Hadrian and St. Helena," 70; Lenski, "Empresses in the Holy Land," 113-25; Magness, The Archaeology of the Holy Land, 323-33; Patrich, "The Early Church of the Holy Sepulchre," 101-06; Smith, To Take Place, 77-80; Tsafrir, Ancient Churches Revealed, 1-10; Walker, Holy City, 202-17; Wharton, "The Baptistry of the Holy Sepulcher," 313-25; Wilkinson, "Constantinian Churches in Palestine," 23-27.

${ }^{90}$ Tsafrir, Ancient Churches Revealed, 1-7; See further: Armstrong, "Constantine's Churches," 5-16; Crowfoot, Early Churches in Palestine, 9-15; Drake, "The Return of the Holy Sepulchre," 263-67; Magness, The Archaeology of the Holy Land; Joseph Patrich, "The Early Church of the Holy Sepulchre in the Light of Excavations and Restoration," in Ancient Churches Revealed, ed. by Toram Tsafrir, (Jerusalem: Israel Exploration Society, 1993), 101-17; Wharton, "The Baptistry of the Holy Sepulcher," 313-25; Wilkinson, "Constantinian Churches in Palestine," 23-27.
} 
was accentuated by the height of its dome. Constantine's four churches were each designed to commemorate a specific biblical event and their design demonstrated this. ${ }^{91}$ Archaeological surveys on the Constantinian churches have revealed details on the layout of the churches. According to Tsafrir, while the Mamre church cannot be reconstructed with certainty, the archaeological studies on the Triad of churches have revealed much about their design. The Eleona church was entered through a peristyle court surrounded by porticoes. The atrium included three entrances into the basilica, which was divided into two rows of columns, a nave, and two aisles. The Eleona church was built around a cave on the Mount of Olives where Christians believed Christ taught his disciples secret knowledge before his death. This cave is incorporated into the building and covered by a raised chancel. The chancel included two flights of stairs, one leading into the cave, and one out, so that the procession of worshippers into the cave would not be interrupted. The overall dimensions of the Eleona church was 30 by 19 meters. $^{92}$

The church of the Nativity in Bethlehem is also a basilica with a primary focus on the commemoration of the cave of the Nativity. This church was built in two stages: the first was started by Constantine, and the second came in the sixth century, under Emperor Justinian. The Constantinian church was built with a central octagonal room, each side measuring 7.90 meters. The octagon was covered with a conical wooden roof. In the

\footnotetext{
91 Armstrong, "Constantine's Churches," 13-16; Crowfoot, Early Churches in Palestine, 9-15; Drake, "The Return of the Holy Sepulchre," 263-67; Magness, The Archaeology of the Holy Land, 323-33; Patrich, "The Early Church of the Holy Sepulchre," 101-6; Tsafrir, Ancient Churches Revealed, 1-6; Wharton, "The Baptistry of the Holy Sepulcher," 313-25; Wilkinson, "Constantinian Churches in Palestine," 23-27. 92 Armstrong, "Constantine's Churches," 13-6; Crowfoot, Early Churches in Palestine, 9-15; Magness, The Archaeology of the Holy Land, 323-33; Tsafrir, Ancient Churches Revealed, 1-10; Walker, Holy City, 20217; Wilkinson, "Constantinian Churches in Palestine," 23-27.
} 
center of the floor there was an opening, surrounded by a balustrade that was itself surrounded by a walkway. The worshipers could walk around this opening and view the cave of Christ's Nativity. There was an oculus in the roof that was aligned to shine light on the cave underneath. The main church included a nearly square-shaped basilica $(26.80$ by 27.70 meters) that was divided into four rows of nine columns each, a central hall, and two aisles on either side. The octagonal room was reached by two sets of stairs, one going up and the other going down, to allow for unobstructed traffic to see the cave of the Nativity. Access to the church was gained through three entrances linked to the atrium. According to Tsafrir, the design of the Church of the Nativity, while ideal for allowing easy access to the cave, did not allow space for regular Christian service. If communion was ever offered at the Church of the Nativity, it was most likely limited and offered in uncomfortable conditions. $^{93}$

The most important and lavishly decorated of the three churches of the Triad was the Church of the Holy Sepulchre in Jerusalem. The best surviving contemporary source for the design of the church comes from Eusebius's Life of Constantine, and when combined with the archaeological surveys, scholars believe they can accurately reconstruct its layout. The church was built around the stone quarry of Golgotha, which was leveled so that the stone of Golgotha and the cave that served as the tomb for Christ would be elevated above the surroundings. The main road of Aelia Capitolina, the Cardo Maximus, led to the gatehouse of the church. Steps then lead to the atrium, which was 28

\footnotetext{
93 Armstrong, "Constantine's Churches," 13-16; Crowfoot, Early Churches in Palestine, 9-15; Magness, The Archaeology of the Holy Land, 323-33; Tsafrir, Ancient Churches Revealed, 1-10; Walker, Holy City, 171-84; Wilkinson, "Constantinian Churches in Palestine," 23-27.
} 
by 36 meters in size. The atrium then led to the basilica itself, called the martyrium. Four rows of columns divided the basilica into a central room, surrounded by four aisles. The basilica is believed to have been 36 by 42 meters and 22 meters tall. ${ }^{94}$

According to Tsafrir, much of the material used to create the original Roman basilica which led to Hadrian's temple to Venus was reused in the construction of the Christian basilica after the original had been torn down. Unlike the temple, the Christians did not consider the public Roman building to be impure. To the west of the basilica was a courtyard around the tomb, forming an interior atrium. The southwest side was raised above the rock of Golgotha, which was incorporated into the layout of the new church. Near the rock, the main part of the Holy Sepulchre itself rose above the inner atrium. The Holy Sepulchre would eventually include a rotunda around the tomb which served to ornament the space like a gigantic canopy. The sources talk about a baptistry, which most likely was to the south of the rotunda. ${ }^{95}$ Rooms and chapels surrounded the entrance to the tomb, creating a compound over 130 meters long and 60 wide. $^{96}$

\section{2: Eusebius and Cyril on the Triad}

In his book, Holy City, Holy Places?, Walker argues that Eusebius linked the Church of the Nativity, the Eleona, and the Holy Sepulchre in order to encourage

\footnotetext{
${ }^{94}$ Euseb. Vit. Const. 3.25-41. See also Armstrong, "Constantine's Churches," 13-16; Crowfoot, Early Churches in Palestine, 9-15; Drake, "The Return of the Holy Sepulchre," 263-67; Magness, The Archaeology of the Holy Land, 323-33; Patrich, "The Early Church of the Holy Sepulchre," 101-6; Tsafrir, Ancient Churches Revealed, 1-10; Walker, Holy City, 202-17; Wharton, "The Baptistry of the Holy Sepulcher," 313-25; Wilkinson, "Constantinian Churches in Palestine," 23-27.

${ }^{95}$ It. Burg. 593.4-594.4; see also Wharton, "The Baptistry of the Holy Sepulcher," 313-25.

${ }^{96}$ Armstrong, "Constantine's Churches," 13-16; Crowfoot, Early Churches in Palestine, 9-15; Drake, "The Return of the Holy Sepulchre," 263-67; Magness, The Archaeology of the Holy Land, 323-33; Patrich, "The Early Church of the Holy Sepulchre," 101-6; Tsafrir, Ancient Churches Revealed, 1-10; Walker, Holy City, 202-17; Wharton, "The Baptistry of the Holy Sepulcher," 313-25; Wilkinson, "Constantinian Churches in Palestine," 23-27.
} 
Constantine's interests in the province of Palaestina, but also to keep him from pouring too much wealth into the city of Jerusalem, a rival city to Caesarea, where Eusebius was bishop. Nevertheless, Constantine placed a great deal of imperial attention on the city of Jerusalem, even funding the construction of the Holy Sepulchre. ${ }^{97}$ As discussed in chapter 2.2, Jerusalem was a rival city to Caesarea and the bishops of Jerusalem actively wanted to take the authority of the metropolitan see away from Caesarea. Eusebius needed to remain in the emperor's favor and praise the Holy Sepulchre, which Constantine valued, but he also hoped to shift Constantine's attention away from Jerusalem. Palaestina was a region rich with biblical history, and Eusebius wanted to encourage Constantine to develop outside of Jerusalem and move imperial funds into other sites of Christian history. ${ }^{98}$

In his account of Helena's pilgrimage to Palaestina and the development of the Church of the Nativity and the Eleona, Eusebius tried to draw focus outside the city of Jerusalem. For Eusebius, it was important to remind Christians of Palaestina's rich history. Before Constantine's creation of the Holy Sepulchre, there was a well-recorded Christian tradition in multiple other locations throughout Palaestina, sites Eusebius discussed at various points in Proof of the Gospel. ${ }^{99}$ Before the rediscovery of the tomb of Christ and the creation of the Holy Sepulchre, the location of the birth of Christ and the site of Christ's ascension into heaven were two of the most important sites for

\footnotetext{
${ }^{97}$ Euseb. Vit. Const. 3.30; see also Walker, Holy City, 192; Telfer, Cyril of Jerusalem, 47.

${ }^{98}$ Drijvers, Cyril, 19-30; Eliav, God's Mountain, 135-40; McCauley, The Works of Saint Cyril of Jerusalem, 14-18; Rubin, "The Cult of the Holy Places," 151-53; Telfer, Cyril of Jerusalem, 19-20; Walker, Holy City, 22-31.

${ }^{99}$ Euseb. Dem. Ev. 1.1.2, 3.2.47, 6.18.23, 7.2.14, 7.2.37. See also Drijvers, Cyril, 15; Walker, Holy City, 192.
} 
Christians in Palaestina. Eusebius worked to keep them equally important to the Holy Sepulchre in the minds of Christians. The benefit of the Triad was that it spread attention to Bethlehem six miles to the south and away from Jerusalem. This was a political move to make it clear that there was a lot to Christianity outside of Jerusalem. Cyril, the bishop of Jerusalem, did not share this opinion. ${ }^{100}$

As will be discussed below, Eusebius thematically linked his three churches around caves significant to the life of Jesus. The cave of the Nativity in Bethlehem, the cave at the Eleona on the Mount of Olives where Christ taught his disciples secret knowledge, and finally the cave of Christ's tomb at the Holy Sepulchre all became the sites of Constantinian churches. It is this theme of the three holy caves that unite the Triad into a cohesive whole for Eusebius. These caves represent Christ's birth, death and resurrection, and final ascension into heaven. Together, these three churches focused around these three caves symbolize the entire story of humanity's redemption through Christ. ${ }^{101}$

Cyril ignored Eusebius's foundational premise for the three churches. While Cyril admitted that these churches were built on sites of great significance to Christianity, there

\footnotetext{
${ }^{100}$ Bitton-Ashkelony, "The Attitudes of Church Fathers," 199; Bowman, "Mapping History's Redemption," 163-67; Crowfoot, Early Churches in Palestine, 9-15; Drijvers, Cyril, 11-21; Eliav, God's Mountain, 135-40; Holum, "Hadrian and St. Helena," 66; Lenski, "Empresses in the Holy Land," 113-25; Potter, Constantine, 275-84; Rubin, "The Cult of the Holy Places," 151-54; Tsafrir, "Byzantine Jerusalem," 136-39; Walker, Holy City, 194-96.

${ }^{101}$ Euseb. Vit. Const. 3.25-43; see also Walker, Holy City, 194-96. For specifics, Eusebius discusses the three caves at multiple points. Most significantly, Eusebius discusses the cave of the Nativity in Const. 3.43.1 and Euseb. Dem. Ev. 3.2.47. Eusebius discusses that the cave at the Mount of Olives marks the "true account" ( $\lambda \dot{o} \gamma o \varsigma \dot{\alpha} \lambda \eta \theta \varsigma \dot{\eta} \varsigma)$ of Jesus to his disciples. This is the cave where Jesus gave his followers secret knowledge of the "ineffable mysteries." in Vit. Const. 3.43.3. Finally, the cave of Christ's death, which Eusebius calls the "cave of the resurrection" is discussed in detail in Eusebius's account of the Holy Sepulchre in Vit. Const. 3.26. In each instance, Eusebius spends a great deal of time, sometimes even more time than he does on the buildings of the basilicas themselves, on the significance of the caves of the churches of the Triad.
} 
was no unifying theme that separated them from any other. For Cyril, the church of the Holy Sepulchre, and the rock of Golgotha, around which the church was built, was the most important site in all the world. In fact, Cyril even argued that the rock of Golgotha was "the very center of the world ( $\tau \tilde{\eta} \varsigma \gamma \grave{\alpha} \rho \gamma \tilde{\eta} \varsigma \tau \grave{o} \mu \varepsilon \sigma \omega ́ \tau \alpha \tau o v)$ "102 However, Cyril did not apply any more significance to either the Church of the Nativity or the Eleona than he did any other church. The Holy Sepulchre took primacy; all other churches were secondary. ${ }^{103}$ Cyril did not want to shift Christian attention away from Jerusalem. The Holy Sepulchre was the most important site for Christians on earth, and Cyril aggressively pushed for pro-Jerusalem standpoint in his writings. ${ }^{104}$ The following subsections examine each of the three churches of the Triad and how both Eusebius and Cyril interpreted them.

\section{a) The Church of the Nativity in Bethlehem}

Eusebius's earliest account of the site of the Nativity appears in his Proof of the Gospel, written sometime between 318-323, years before the creation of the Church of the Nativity. In this account, Eusebius discussed the rich Christian history of the site and the many traditions that had developed over the centuries. He focused on the cave of Christ's birth and is quite confident in the site's widespread interest for Christians, even stating that many people "come from abroad to see it." 105 This site was important "because of its history" as the place where "the Virgin gave birth and laid her infant" and

\footnotetext{
${ }^{102}$ Catech. 13.28; See also Drijvers, Cyril, 74, 156; Kalleres, "Cultivating True Sight at the Center of the World," 434, 451; Walker, Holy City, 254-56.

${ }^{103}$ Drijvers, Cyril, 11-21; Kalleres, "Cultivating True Sight at the Center of the World," 434, 451; Walker, Holy City, 194-98.

${ }^{104}$ Catech. 13.28; see also Drijvers, Cyril, 156; Kalleres, "Cultivating True Sight at the Center of the World," 434, 451; Walker, Holy City, 254-56.

${ }^{105}$ Euseb. Dem. Ev. 1.1.2; see also Walker, Holy City, 192.
} 
that the locals received the "tradition from their fathers." ${ }^{106}$ Eusebius was convinced in the authenticity of the history and tradition of this site. He argued that the locals who know of this significance testify to its authenticity and its history to visitors. ${ }^{107}$ For Eusebius, the site of the Nativity was critical for Christians because it was the beginning of the story of Christ's salvation, the location of Jesus' birth. Eusebius claimed that Christians were called to "worship the ground he stood on" and that Bethlehem was the perfect place to do this. ${ }^{108}$ Within a few years of his writing this account about Bethlehem as one of the most significant sites in the Proof of the Gospel, the cave of the Nativity became the site of one of Constantine's three basilicas.

Eusebius discussed the creation of the Triad of Churches in detail in his Life of Constantine. Eusebius split his account of the Triad of churches into two sections. The first, longer section, recounted the creation of the Holy Sepulchre church. The second, shorter section, detailed the pilgrimage of Helena, mother of Constantine, to Palaestina. ${ }^{109}$ Eusebius credited Helena with the dedication of the two remaining churches of the Triad, the Church of the Nativity and the Eleona. Outside of his narrative of Helena's pilgrimage, Eusebius never directly addressed either the church of the Nativity or the Eleona church. It is important, therefore, to discuss Eusebius's account of Helena's pilgrimage in order to understand how Eusebius understood the Triad of Churches.

\footnotetext{
${ }^{106}$ Euseb. Dem. Ev. 3.2.47; see also Walker, Holy City, 192.

${ }^{107}$ Euseb. Dem. Ev. 7.2.14; see also Drijvers, Cyril, 15.

${ }^{108}$ Euseb. Dem. Ev. 7.2.37; see also Walker, Holy City, 192.

${ }^{109}$ Euseb. Vit. Const. 3.25-43. Chapters 25-40 detail the creation of the Holy Sepulchre, chapters 41-43 recount Helena's pilgrimage and the dedication of the church of the Nativity and the Eleona.
} 
Eusebius began his narrative of Helena's pilgrimage by stating that she "hastened with youthful alacrity to survey this venerable land ( $\sigma \pi \varepsilon v ́ \delta o \sigma \alpha \tau \grave{\eta} v \dot{\alpha} \xi ı \alpha \alpha \dot{\alpha} \sigma \tau o v$ $\dot{\alpha} v \imath \sigma \tau o \rho \dot{\eta} \sigma o v \varsigma \gamma \tilde{\eta} v) .{ }^{\prime 110}$ Eusebius does not mention the city of Jerusalem even once in his account of Helena's pilgrimage. When he says the land Helena surveyed was "venerable," he was referring to the whole of Palaestina, divorced from Jerusalem. Even though the previous section was four times as long and dealt exclusively with the Holy Sepulchre in Jerusalem, Eusebius never referred to Jerusalem with such positive language. This implies the land of Palaestina itself was significant, and not just the individual sites dealing with the life of Jesus. ${ }^{111}$

Eusebius ascribed a clear significance to the ground Jesus walked on. This notion goes back even to his earliest account of Bethlehem in Proof of the Gospel. ${ }^{112}$ In his account of Helena's pilgrimage, he said she visited the caves at Bethlehem and the Mount of Olives. Helena saw the cave Jesus was born in, and the cave at the summit of the Mount of Olives. These sites were undeveloped when Helena visited them. She then initiated the construction of the churches, which would be finished years later. Eusebius provided a passage from the book of Psalms in the Bible in his description of Helena's pilgrimage, "Let us adore in the place where his feet have stood." ${ }^{113}$ Eusebius interprets this passage from the old testament as a prophecy which is fulfilled through Helena's pilgrimage to Palaestina. Helena, called to her pilgrimage by divine guidance, was

\footnotetext{
${ }^{110}$ Euseb. Vit. Const. 3.42; see also Rivers, "Pattern and Process," 184.

${ }^{111}$ Drijvers, Cyril, 21-26; Holum, "Hadrian and St. Helena," 66; Lenski, "Empresses in the Holy Land," 113-25; Potter, Constantine, 275-84; Rivers, "Pattern and Process," 184.

112 Euseb. Dem. Ev. 7.2.37; see also Walker, Holy City, 192.

${ }^{113}$ Euseb. Vit. Const. 3.42; Psalm 132:7; see also Drijvers, Cyril, 174; Walker, Holy City, 192.
} 
fulfilling the prophecy in the Bible. By going to the Holy Land, Helena further honored the ground upon which Christ stood and built the necessary churches to bring Christian attention back to the "venerable land" which was the land of Christ. ${ }^{114}$

Eusebius made several direct connections between Helena, the mother of the Emperor Constantine, and Mary, the mother of Jesus Christ. He described how "The most devout empress honored the Godbearer's pregnancy with wonderful monuments $(\beta \alpha \sigma i \lambda i \varsigma$

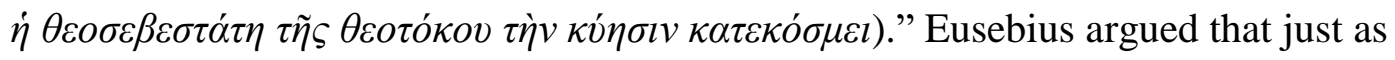
Constantine, the earthly king, honored Christ, the heavenly king, his mother, the "pious mother of a pious king $(\theta \varepsilon o \varphi \imath \lambda o \tilde{v} \varsigma \beta \alpha \sigma l \lambda \dot{\varepsilon} \omega \varsigma \theta \varepsilon o \varphi \imath \lambda \dot{\eta} \varsigma \mu \dot{\eta} \tau \eta \rho)$," honored the birth of the

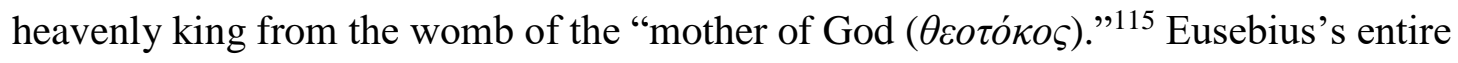
account of Helena's pilgrimage is filled with praise of the royal mother. These few paragraphs dealing with two significant churches spent just as much time praising Helena, and by extension Constantine, as they spent on describing the churches themselves. Eusebius wanted to make it clear that not only was the land itself sacred for its connection to Christ, but the people responsible for the churches developed in this land were also worthy of praise. Eusebius worked to keep Constantine's interest fixed on Palaestina even after he funded the Holy Sepulchre. ${ }^{116}$

Although Cyril and Eusebius disagreed on many political and theological points, they both acknowledged the historical and theological significance of the site of Christ's birth. Cyril praised Bethlehem as the place where Jesus descended from heaven to be

\footnotetext{
${ }^{114}$ Bowman, "Mapping History’s Redemption," 163-67; Drijvers, Cyril, 174; Walker, Holy City, 192.

${ }^{115}$ Euseb. Vit. Const. 3.43; see also Drijvers, Cyril, 174; Walker, Holy City, 192.

${ }^{116}$ Walker, Holy City, 187.
} 
born into the world. ${ }^{117}$ Cyril even addressed the virgin birth of Christ, and the blessings of Mary, the mother of God, in his lectures. Both Eusebius and Cyril used the exact same

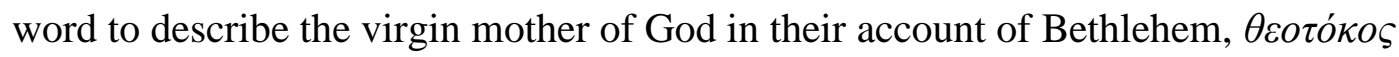
(mother of God). ${ }^{118}$ For both Eusebius and Cyril, Bethlehem, and the site of the Nativity, was a central location for the Christian faith, the place where Christ had entered the world, and both bishops recognized and agreed with each other on the significance of the history of Bethlehem. However, Cyril and Eusebius's opinions differed greatly concerning what the history of Bethlehem meant for Jerusalem and Palaestina. ${ }^{119}$

Cyril rejected the very notion of a Triad of Churches that together create a unified Christian narrative of salvation. While Eusebius worked hard to demonstrate that these churches were significant not only because of their history, but also because God had marked all three places through their connections to holy caves, Cyril never once referred to any of the churches in Eusebius's Triad as caves, even when it made sense to do so. Other Christian historians would refer to both Bethlehem and the Mount of Olives as sites housing caves of significance to Christianity. Egeria, in her account of her pilgrimage in the early 380s, references the Mount of Olives as the site of the "cave where the Lord taught." ${ }^{\text {"20 }}$ For Cyril, the Nativity was not connected to a cave, but to the manger. On multiple occasions throughout these lectures Cyril referenced Bethlehem and the birth of Christ. He described the manger as still existing and testifying to Christ. "The place of

\footnotetext{
${ }^{117}$ Catech. 14.23; see also Drijvers, Cyril, 174; Walker, Holy City, 197.

118 Catech. 14.23; Euseb. Vit. Const. 3.43; see also Walker, Holy City, 179.

119 Bowman, "Mapping History's Redemption," 163-67; Drijvers, Cyril, 174; Walker, Holy City, $194-96$.

${ }^{120}$ Egeria, e.g. 33.1-2, 39.3, 35.2-3; see also Walker, Holy City, 195.
} 
the manger, which received the lord, will put them [pagans] to shame." ${ }^{121}$ Yet, throughout the multiple references to Bethlehem he never once connected either the history of Christ's birth, or the contemporary Constantinian basilica, with a cave. According to Walker, Cyril, who was familiar with Eusebius's writings and political views, was intentionally rejecting Eusebius's views of the Triad of churches and strategically uses his words to bypass the unifying element that linked the Triad of churches that Eusebius worked so hard to create. ${ }^{122}$

Eusebius developed the Triad as a means of distancing Christian history from Jerusalem by placing an equal focus on Bethlehem and the Mount of Olives, yet little more than a decade later Cyril never admitted any unifying theme to these three churches. He incorporated these historical Christian sites as part of the heritage of Jerusalem. In one of his lectures given in the Holy Sepulchre, Cyril claimed Bethlehem was part of the history of Jerusalem. He argued that Jesus descended "here in Jerusalem ( $\dot{\varepsilon} v \tau \alpha \tilde{v} \theta \alpha \dot{\varepsilon} v \tau \tilde{\eta}$

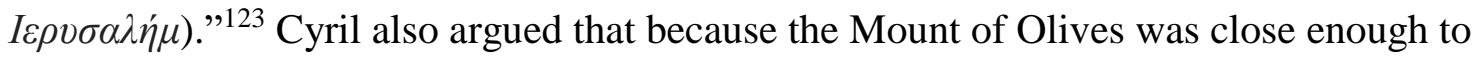
Jerusalem that it could be seen from within the city wall, it was also a part of Jerusalem. ${ }^{124}$ In Cyril's mind, Bethlehem and the Mount of Olives were not just near Jerusalem, they were extensions of Jerusalem. Cyril took the Triad of churches that Eusebius created to distance Christianity from Jerusalem and claimed them as part of the cultural and historical heritage of Jerusalem, thus creating a Christian Jerusalem as the center of Palaestina.

${ }^{121}$ Catech. 10.19, 12.32; see also Drijvers, Cyril, 154; Walker, Holy City, 194-96.

122 Walker, Holy City, 194-98.

123 Catech. 16.4, Walker, Holy City, 197. Original Greek from Cyril obtained from the Migne Codex.

${ }^{124}$ Drijvers, Cyril, 11-21, 75-83, 174; Walker, Holy City, 196-98. 


\section{b) The Eleona At the Mount of Olives}

The Mount of Olives, much like site of the Nativity in Bethlehem, had a long Christian tradition before Constantine began to transform Palaestina, and it was because of this long tradition that these sites were chosen for the basilicas. Eusebius's earliest writings about the Mount of Olives predated any involvement from Constantine by over a decade. In Proof of the Gospel, Eusebius establishes the Mount of Olives as the focus for all Christian Palaestina. Christians visited the Mount of Olives "from all over the world" to "learn about the city being taken and devastated" and to "worship [there] opposite

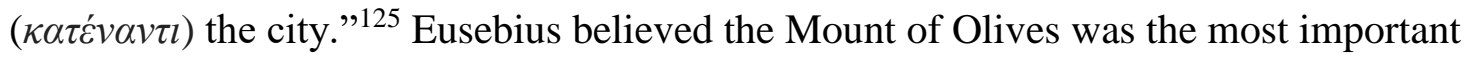
site in all Palaestina. ${ }^{126}$ He developed this belief to establish the Mount of Olives as opposed to the city of Jerusalem. ${ }^{127}$

One of the key points Eusebius used to establish this argument is the Old Testament passage from the prophet Zechariah which prophesized that the messiah's feet shall stand on the Mount of Olives which lies to the east of Jerusalem. ${ }^{128}$ For Eusebius, the ascension of Christ on the Mount of Olives was the fulfillment of Jesus's entire life; it marked the culmination of Christ's accomplishments. Eusebius interpreted Zechariah's prophecy as referring to that very moment when Christ stood on the Mount of Olives and ascended into heaven. For Eusebius, Christ's ascension outside the city was a sure sign for all future generations of his judgment on Jerusalem. ${ }^{129}$ Christians from that point on

\footnotetext{
${ }^{125}$ Euseb. Dem. Ev. 6.18.23; see also Drijvers, Cyril, 15; Walker, Holy City, 200.

${ }^{126}$ Drijvers, Cyril, 15-24; Walker, Holy City, 201-5.

${ }^{127}$ Euseb. Dem. Ev. 6.18.4-26; see also Walker, Holy City, 205-10.

${ }^{128}$ Euseb. Dem. Ev. 6.18.23; Zech 14.4; see also Walker, Holy City, 205-10.

${ }^{129}$ Crowfoot, Early Churches in Palestine, 30-34; Drijvers, Cyril, 15; Walker, Holy City, 206.
} 
were no longer called to worship either at the Jewish temple or even in the city that Jesus himself abandoned. According to Eusebius, Christians were called to "worship at the Mount of Olives opposite to the city." 130 Now Christians were called to go to all parts of the world and spread the name of Christ. Christians were free to worship on the Mount of Olive opposite ( $\left.\kappa \alpha \tau^{\prime} v \alpha v \tau \imath\right)$ the city. ${ }^{131}$ The Mount of Olives had replaced Jerusalem, which was never to rise again $(\mu \grave{\eta} \dot{\varepsilon} \gamma \varepsilon \rho \theta \varepsilon i \sigma \eta \varsigma) .{ }^{132}$ Jerusalem, according to Eusebius, then had lost not only its temple, but also its glory. He called Jerusalem "the former city ( $\tau \grave{\eta} v$

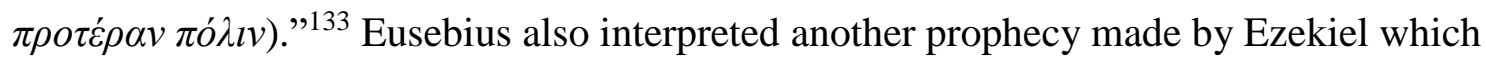
promised the glory of God would fall on the Mount of Olives. ${ }^{134}$ He said that being to the east, the Mount of Olives was in a perfect location to receive the divine rays of God's light. ${ }^{135}$ Proof of the Gospel is the most explicit of Eusebius's writings against Jerusalem, which he could not risk overtaking Caesarea as the center of Palaestina.

Eusebius's earliest account of the significance of the Mount of Olives was in his Proof of the Gospel, which he wrote after tensions grew between Caesarea and Jerusalem, but before Eusebius ever met with Constantine. This work is one of his clearest examples of his political attacks on Jerusalem through his promotion of the Mount of Olives as its replacement. However, over the next decade, Eusebius gained a

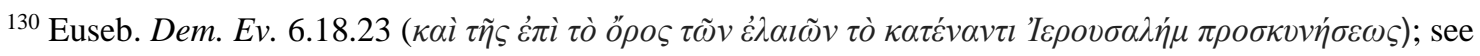
also Walker, Holy City, 206.

${ }^{131}$ Euseb. Dem. Ev. 6.18.23; see also Crowfoot, Early Churches in Palestine, 30-34; Eliav, God's Mountain, 134-40; Walker, Holy City, 206.

${ }^{132}$ Euseb. Dem. Ev. 6.18.20-22; see also Walker, Holy City, 223.

${ }^{133}$ Euseb. Dem. Ev. 6.18.23; see also Walker, Holy City, 223.

${ }^{134}$ Euseb. Dem. Ev. 6.18.20-22, 26; Zech 14.4; Ezk. 11.22-3 "Then the cherubim, with the wheels beside them, spread their wings, and the glory of the God of Israel was before them. The glory of the LORD went up from within the city and stopped above the mountain east of it." (trans. NIV).

${ }^{135}$ Euseb. Dem. Ev. 6.18.23-26; see also Walker, Holy City, 223.
} 
position close to Constantine and this changed both men. Jerusalem became a site of central importance for Constantine. Eusebius could no longer openly attack the city as he had done in his earlier writings. Eusebius readdressed the issue of the Mount of Olives after Helena's pilgrimage and the building of the Eleona Church. In Life of Constantine, Eusebius is not openly opposed to the city of Jerusalem, but instead he shifts his attention to the destroyed Jewish temple. He argues that "the New Jerusalem was built over against ( $\dot{\alpha} v \tau \imath \pi \rho o ́ \sigma \omega \pi \circ \varsigma)$ the one so celebrated of old which.... had experienced that last extremity of desolation." ${ }^{136}$ By shifting his discussions to the ruined Jewish temple, Eusebius is still able to discuss God's judgment of Jerusalem without attacking the city that Constantine had started patronizing. The old Jerusalem was symbolized by the temple, which God condemned and was destroyed by the Romans. The Holy Sepulchre, however, represented Christ's New Jerusalem. Overall, in his later writings, Eusebius is much less drastic in his critique of the city of Jerusalem.

While the Mount of Olives was best-known as the site of Christ's ascension, there were other events of biblical history that occurred there. The ascension occurred on the summit of the mountain, but the Eleona church was not built on the summit, but instead on top of a cave near the summit. In the Life of Constantine, Eusebius discussed the cave near the summit of the mountain, where Christ was believed to have taught his disciples hidden mysteries. Eusebius described how this site marked the "true account ( $\lambda$ ó $\gamma \circ \varsigma$ $\dot{\alpha} \lambda \eta \theta \varsigma \grave{\varsigma} \varsigma)$ " of Jesus to his disciples. This is the cave where Jesus gave his followers secret

${ }^{136}$ Euseb. Vit. Const. 3.33; see also Walker, Holy City, 228. 
knowledge of the "ineffable mysteries." 137 Then, according to Eusebius, the Mount of Olives was the site of both the true teachings of Christ to his disciples and the spot of the ascension of Christ, the culmination of the entire gospel. For Eusebius, these events, especially the ascension, marked the site as the central point in the entire gospel narrative and the mountain was of critical importance to Christianity. This location was worthy of Helena's pilgrimage and the basilica that she would build there. The Eleona church, one of the three in Eusebius's Triad, was built to honor this rich Christian history on the Mount of Olives. Eusebius's account of the church in the Life of Constantine, while still arguing against the centrality of Jerusalem, was less critical of the city than the Proof of the Gospel.

Cyril held very different opinions concerning the Mount of Olives and the Eleona church. Unlike Eusebius, who worked to separate the Mount of Olives from Jerusalem, Cyril incorporated the mount into the cultural heritage of Jerusalem. They were not standing apart, in judgment of each other, they were bound together as a cohesive whole. The two sites were less than a mile apart. For Cyril, this closeness justified their collection as part of the true Jerusalem. ${ }^{138}$ Cyril referenced the Mount of Olives seven times in his lectures. In all but two of these passages, he referred to it specifically as the site of Christ's ascension. Similar to the church of the Nativity in Bethlehem, Cyril refused to refer to the Eleona church as a cave. Nor did he ever reference a cave in his

\footnotetext{
${ }^{137}$ Euseb. Vit. Const. 3.43.3; see also Armstrong, "Constantine's Churches," 13-16; Crowfoot, Early Churches in Palestine, 9-15; Magness, The Archaeology of the Holy Land, 323-33; Tsafrir, Ancient Churches Revealed, 1-10; Walker, Holy City, 202-17; Wilkinson, "Constantinian Churches in Palestine," 23-27.

138 Walker, Holy City, 219-22.
} 
discussions related to the church. He refused to consider the Triad of churches on any grounds that would validate Eusebius's anti-Jerusalem interpretation of the historic sites. $^{139}$

Cyril gave his lectures to his catechumens from within the Holy Sepulchre. From this vantage point, he stated that there are a multitude of witnesses within the vicinity to Christ. These witnesses not only included the Holy Sepulchre itself, which testified to the death and resurrection of Christ, but also the "place of the Ascension." The site of Christ's ascension, the Mount of Olives, was next to the resurrection, the Holy Sepulchre. ${ }^{140}$ These sites were not opposed, as Eusebius argued in Proof of the Gospel, instead they were two parts of a single story of Christ's redemption. The Mount of Olives was not distant, but an integral part of Cyril's Jerusalem.

Eusebius believed that the account of the prophet Zechariah created opposition between the Mount of Olives and the city of Jerusalem. Cyril, however, thought that Zechariah never intended any opposition in his words, Zechariah only states the geographic fact that the Mount of Olives is "to the east" of the city of Jerusalem. ${ }^{141}$ In Cyril's mind, Christ's ascension occurring on the Mount of Olives, outside the city of Jerusalem, held no condemnation on the city. Eusebius believed the ascension was the end of the story of Christ's salvation, the central theme of the gospels, and therefore it was significant that it occurred outside of Jerusalem. However, Cyril believed the

${ }^{139}$ Catech. 2.12, 4.13-14, 10.19, 12.10-11, 13.38, 14.23, 14.25; see also Walker, Holy City, 216-17. In 14.23 Cyril references the Mount of Olives as site of the ascension, next to the place of the resurrection (Holy Sepulchre). In 10.19, the Mount of Olives is a "heavenly gate." In 14.23, Christ is crowned. In 12.1011, Cyril links Psalm Sunday with prophecy from Zechariah (14.4) which says Jesus will walk on the Mount of Olives, thus disagreeing with Eusebius's interpretation.

${ }^{140}$ Catech. 14.23; see also Walker, Holy City, 220.

${ }^{141}$ Catech. 4.14, 14.23, 14.25; see also Walker, Holy City, 220. 
ascension was not the end of the biblical story. Instead, he argued that after the ascension, the disciples immediately returned to the city and then they received the blessings of the holy spirit during Pentecost. ${ }^{142}$ The Biblical story continued after Christ's ascension, and the Mount of Olives was simply another location, near enough to Jerusalem, that witnessed one of the many significant events. Together, all these places created a unified biblical story, with Jerusalem at the center of events.

The single best passage to demonstrate Cyril's positive view of the biblical events relating to the Mount of Olives and its relationship with Jerusalem comes from his twelfth lecture. Here Cyril discussed Palm Sunday, where he states that Jesus left the Mount of Olives and entered Jerusalem "with acclaims as king." ${ }^{143}$ He stated that the Mount of Olives was an ever-present sign to the people of Jerusalem, forever "nearby and clearly visible, that being in the city we may behold the place." ${ }^{144}$ In this context, Cyril offers the antithesis of Eusebius's argument. The Mount of Olives is not standing apart from Jerusalem in judgment. Instead the Mount of Olives is God's sign to the people of Jerusalem, clearly visible both from within the city and from without, impossible to avoid, that Christ is king. Cyril's account of Palm Sunday ignored the more violent sections of the story, namely Christ's clearing of the temple, and instead only referenced the short-lived moments where Christ entered the city and is received by popular acclamation as king. ${ }^{145}$ Cyril then argued that Jerusalem now accepts the kingship of

\footnotetext{
142 Catech. 14.23; see also Walker, Holy City, 220-21.

143 Catech. 12.10; see also Walker, Holy City, 220-21.

${ }^{144}$ Catech. 12.11; see also Walker, Holy City, 220-21.

${ }^{145}$ Mark 11:1-11, Matt 21:1-11, Luke 19:28-44, and John 12:12-19. For the story of Jesus cleansing the temple see: Mark 11.15-19, Matt 21.12-17, Luke 19.45-48, and John 2.13-16.
} 
Christ. While the city originally rejected Jesus, the New Jerusalem now worships him as God. ${ }^{146}$

\section{c) The Holy Sepulchre in Jerusalem}

Christians of all persuasions acknowledged their common origins in the death and resurrection of Jesus Christ. The Holy Sepulchre was the most significant object of Christian attention in 325 and its centrality is discussed in all three of our sources. ${ }^{147}$ Eusebius, Cyril, and the Bordeaux pilgrim all spend more time discussing the church of the Holy Sepulchre than their accounts of the other two churches in the Triad. Eusebius's account of the Holy Sepulchre in his Life of Constantine is more than four times longer than his account of the Church of the Nativity and the Eleona combined. ${ }^{148}$ While Cyril mentions the Church of the Nativity and the Mount of Olives on multiple occasions throughout his lectures, he gave these lectures from within the Holy Sepulchre and therefore the church becomes a theme that repeats throughout each of his lectures. ${ }^{149}$ Eusebius began his account of the Holy Sepulchre by describing the motivations for Constantine, the "God-beloved ( $\theta \varepsilon o \varphi \imath \lambda \grave{\eta} \varsigma)$," who desired to make the most blessed site of Christ's resurrection universally famous and revered. According to Eusebius, Constantine was not acting out of selfish desires, but instead had "his spirit moved by the

\footnotetext{
${ }^{146}$ Drijvers, Cyril, 21.

${ }^{147}$ Euseb. Vit. Const. 3.25-41; Catech. 1.1, 4.14, 5.10, 10.19, 13.4, 13.22, 13.23, 13.26, 13.28, 13.32, 16.4, It. Burg. 593.4-5994.4; see also Walker, Holy City, 235.

${ }^{148}$ Euseb. Vit. Const. 3.25-47. The first sixteen chapters of this section, 3.25-40, chronicle the discovery and building of the Holy Sepulchre. The last three chapters of this section, 3.41-3, discuss Helena's pilgrimage and the building of the Church of the Nativity and the Eleona at the Mount of Olives. ${ }^{149}$ Cyril discusses Bethlehem and the Church of the Nativity in Catech. 10.19, 12.32, 14.23, and 16.4. He references the Mount of Olives and the Eleona in Catech. 2.12, 4.13-14, 10.19, 12.10-11, 13.38, 14.23, 14.25. Cyril directly references the Holy Sepulchre and the rock of Golgotha within the church in Catech. $1.1,4.9-12,4.14,5.10,10.19,13.1,13.8,13.4,13.19-20,13.22-3,13.26,13.28,13.32,13.34-5,13.37-9$, $13.55,14.5,14.9-12,14.20,14.22,15.22,16.4$, and 18.16 . This list is not exhaustive.
} 
savior himself." ${ }^{150}$ Eusebius then described the history of the cave of Christ's

resurrection, which he calls "the divine monument to immortality." ${ }^{151} \mathrm{He}$ described how, under Emperor Hadrian, "some godless and wicked people" tried to make the cave invisible to all mankind, thinking they could hide the truth. They leveled the cave, paved over it, and on top of it built the temple to Venus, which Eusebius described as a temple for dead idols and the impure demon Venus. ${ }^{152}$ They wanted to bury the savior's tomb under pollutions of foul sacrifices. Eusebius then proclaims that the savior could not be hidden. Constantine, possessed by divine spirit, calling upon God as collaborator, ordered the place to be cleared and the site the wicked wished to cover be made even more holy. In so doing he destroyed their idols and demons. Constantine ordered that all stones and timbers from the demolitions should be removed from the site so that they may no longer pollute the most sacred space. As the temple to Venus was removed, and the foundations dug up, Eusebius described how against all expectations, the "all-hallowed testimony

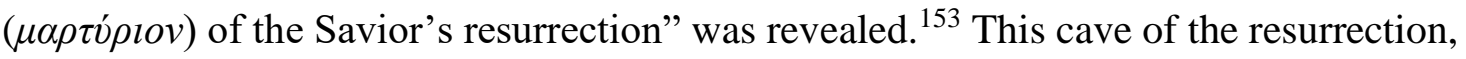
which he calls the "holy of holies ( $\ddot{\alpha} \gamma l o v \tau \tilde{\omega} v \dot{\alpha} \gamma i \omega v)$ " spent centuries in darkness, but now it had come back into the light. He praised how the site of the "Savior's resurrection" testifies by facts louder than any voice ever could. ${ }^{154}$ As previously discussed,

\footnotetext{
${ }^{150}$ Euseb. Vit. Const. 3.25 .

${ }^{151}$ Euseb. Vit. Const. 3.26.

${ }^{152}$ Euseb. Vit. Const. 3.28; Walker, Holy City, 192; Drijvers, Cyril, 16; Potter, Constantine, 276-7; Smith, To Take Place, 79-82.

${ }^{153}$ Euseb. Vit. Const. 3.28; Walker, Holy City, 192; Drijvers, Cyril, 16; Potter, Constantine, 276-7; Smith, To Take Place, 79-82.

${ }^{154}$ Euseb. Vit. Const. 3.28; Walker, Holy City, 192; Drijvers, Cyril, 16; Potter, Constantine, 276-7; Smith, To Take Place, 79-82.
} 
Constantine poured imperial funds into the Holy Sepulchre, the most important site in Palaestina, to make it the most beautiful basilica in the world.

Due to his relationship with Constantine, Eusebius was forced into a delicate situation. Constantine was pouring money into Jerusalem for the Holy Sepulchre, which threatened Caesarea's position as the political and religious center of Palaestina. Eusebius did not want to promote Jerusalem, but he did not want to risk his own position and rank. Therefore, he carefully described Constantine's development of Jerusalem. He was clear that Jerusalem was the city that rejected Jesus and was rightfully judged for this failure. ${ }^{155}$ Eusebius never changed his views on this matter. However, he toned down his earlier rhetoric towards the city of Jerusalem. It had been over a decade since he provided such a critical account of Jerusalem, and through his interactions with the Emperor, his opinions, at least publicly, had been moderated. He stated that while the old Jerusalem had been destroyed by God's wrath and paid the penalty of its wicked inhabitants, the Holy Sepulchre represented a New Jerusalem, built at the very testimony to the Savior. The sacred cave, a tomb full of age-long memory of the great savior's defeat of death, was a tomb of divine presence. On this spot, an angel of radiant light proclaimed the good news of Christ's resurrection. ${ }^{156}$ In this way, Eusebius simultaneously passed judgment on Jerusalem, while proclaiming the glory and significance of Constantine's Holy Sepulchre. Throughout this passage, Eusebius never referred to the contemporary city of

\footnotetext{
${ }^{155}$ Eusebius discusses the theological effects of God's judgment on Jerusalem and its destruction in 70 and 135 at various points. Most explicitly he makes this point in Proof of the Gospel, Dem. Ev. 1.3.1-3, 3.2.10. For more discussion on this issue, see Walker Holy City, 61-65.

${ }^{156}$ Euseb. Vit. Const. 3.25-41.
} 
Jerusalem by name, he always referred to the Holy Sepulchre, one of his Triad of Churches, instead of the city. ${ }^{157}$

Not only did Eusebius not mention the city of Jerusalem of his time in his account of the Holy Sepulchre, he was also very careful in his language not to mention, even once, the rock of Golgotha, or even the name Golgotha, which was a central point in the Holy Sepulchre church. Archaeological surveys show that one of the central rooms in the Holy Sepulchre was focused entirely around the rock of Golgotha. It would have been impossible to miss this significant element with even a basic understanding. ${ }^{158}$ This oversight could not have been accidental. Eusebius, then, must have intentionally left out one of the key components of the Holy Sepulchre. The rock of Golgotha, according to the Bible, was the spot on which Christ was crucified. ${ }^{159}$ For Eusebius, the Holy Sepulchre was the site of Christ's burial and resurrection, the fact that the basilica also covered the spot of Christ's death was not even worth mentioning. Eusebius went as far as to refer to the tomb at Calvary almost exclusively as the cave of the resurrection, not the tomb of the death of Christ. He described the cave that served as Christ's tomb with words like

\footnotetext{
${ }^{157}$ Euseb. Vit. Const. 3.31-33; see also Walker, Holy City, 192, Drijvers, Cyril, 20. Telfer, Cyril of Jerusalem, 43.

${ }^{158}$ Armstrong, "Constantine's Churches," 13-16; Bitton-Ashkelony, "The Attitudes of Church Fathers," 188-89; Bowman, "Mapping History's Redemption," 163-67; Crowfoot, Early Churches in Palestine, 9-15; Drake, "The Return of the Holy Sepulchre," 263-67; Drijvers, Cyril, 11-21; Eliav, God's Mountain, 12326; Holum, "Hadrian and St. Helena," 66; Lenski, "Empresses in the Holy Land," 113-25; Magness, The Archaeology of the Holy Land, 323-6; Potter, Constantine, 207-14; Schiffman, "Jerusalem," 36-7; Stenger, "Eusebius and the Representation of the Holy Land," 382-87; Telfer, Cyril of Jerusalem, 43-7; Tsafrir, Ancient Churches Revealed, 2-11; Tsafrir, "Byzantine Jerusalem," 133-39; Wharton, "The Baptistry of the Holy Sepulcher," 313-21; Walker, Holy City, 171-84; John Wilkinson, "Constantinian Churches in Palestine," in Ancient Churches Revealed, ed. by Toram Tsafrir (Jerusalem: Israel Exploration Society, 1993), 24-27.

${ }^{159}$ Mk 15:22, Mt 27:33, Lk 23:33, and Jn 19:17-20.
} 
resurrection ( $\dot{\alpha} v \alpha \dot{\sigma} \sigma \tau \alpha \sigma \varsigma)$ and immortality ( $\dot{\alpha} \theta \alpha v \alpha \sigma i \alpha)$. He never connected the cave with Christ's death. ${ }^{160}$

In a later speech given when the Holy Sepulchre was finally completed, Eusebius did not even mention Christ's burial at all. ${ }^{161}$ In this speech, instead of discussing the tomb of Christ's death, Eusebius talked about the cave of Christ's resurrection. Eusebius linked the cave of the Holy Sepulchre with the other two caves of his Triad of Churches, and he shifted the theological debate away from Christ's death to his resurrection and immortality, two issues Eusebius was much more interested in discussing. Through the resurrection of Christ, Christians were able to gain their own victory over death. The victory of Christ's logos over death is the "prototype of that immortality and life with God which is our common hope."162 As will be discussed in chapter 4.1, Eusebius worked to create a spiritualized view of Jesus, separated from the physical body and distanced from any specific geographic region. For Eusebius, the resurrection of Christ was the central issue of the Holy Sepulchre, and all other aspects of the church were incidental.

Cyril took a very different approach to his understanding of the Holy Sepulchre. One of the chief differences in opinion concerning the Holy Sepulchre between Eusebius and Cyril deals with the rock of Golgotha. Unlike Eusebius, who did not mention Golgotha at all in his description of the church, Cyril placed Golgotha as a central theme in his lectures, referencing it no less than ten times. When Constantine ordered the temple

\footnotetext{
${ }^{160}$ Euseb. Vit. Const. 3.25, 3.36, 3.28; see also Walker, Holy City, 267.

${ }^{161}$ Euseb. Sep. Chr. Drake, In Praise of Constantine, 31.

${ }^{162}$ Euseb. Sep. Chr. 15.9, 18.3; see also Walker, Holy City, 268-9, Drijvers, Cyril, 19. Drake, In Praise of Constantine, 31 .
} 
of Venus to be torn down and the land under it to be excavated, he was looking for Jesus's tomb, which tradition held Hadrian was trying to hide. ${ }^{163}$ While the foundations of the Holy Sepulchre were being excavated not only was the tomb of Christ uncovered but the rock of Golgotha was also revealed. Cyril states that the rock of Golgotha was

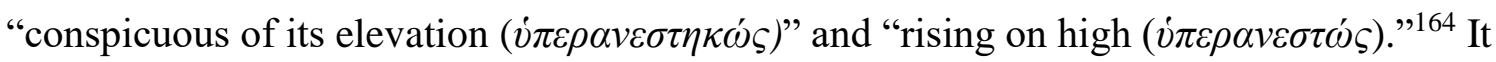
was a key component of his lectures, which, in fact, were usually given in front of it. ${ }^{165}$ This constant reference to Golgotha reflects his entire theological approach to the Holy Sepulchre. It symbolized and represented the central element of the Church and Christianity. Cyril uses the name Golgotha to refer to the entire physical building of the Holy Sepulchre. ${ }^{166}$ For Cyril, Golgotha was the "very center of the world." It marked the death of Christ and his finished salvation for mankind. It was the center of the Holy Sepulchre, Christian theology, and even the Christian Church, the physical manifestation of Christ's death, and as Cyril argues, it was the precise moment that salvation was "worked."167

In one lecture, Cyril is critical of the adornment of the Holy Sepulchre. The tomb of Christ, which Eusebius positioned to represent the resurrection of Christ (the empty tomb), became a tool to spiritualize Christ and distance him from Jerusalem. The tomb was lavishly decorated, but the rock of Golgotha had been left comparatively bare. Cyril felt the basilica focused too much on the resurrection and spirit of Jesus and not the death

\footnotetext{
${ }^{163}$ Drijvers, Cyril, 15; see also Walker, Holy City, 244; Drijvers, Cyril, 15.

${ }^{164}$ Catech. 10.19, 13.39; Walker, Holy City, 252.

${ }^{165}$ Catech. 1.1, 4.14, 5.10, 10.19, 13.4, 13.26, 13.22, 13.23, 13.28, 13.32; see also Walker, Holy City, 254.

${ }^{166}$ Catech. 16.4; see also Walker, Holy City, 255.

${ }^{167}$ Catech. 13.28; see also Walker, Holy City, 256.
} 
and physical body of Christ. Before the imperial adornment of the site, there was a cave in front of the rock which has now been covered. ${ }^{168}$ Cyril opposed this neglect of the central symbol for the death of Christ in favor of a more spiritual Christ. Throughout his lectures he presented an alternative view to establish the true Jesus, freed from the damaging, imperial agenda that Eusebius pushed on Constantine.

Another theme that Cyril developed throughout his lectures was the continuity of the church. Cyril described how many of the elements of Christianity started with Jesus

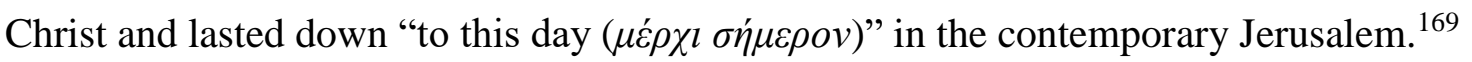
He showed an unbroken connection to Christ. The Cross of Christ was one such symbol that remained for Christians to demonstrate continuity. While Eusebius never directly referenced the discovery of the fragments of the cross in his account of the Holy Sepulchre, later traditions held that Helena discovered the Cross of Christ in her pilgrimage to Palaestina. Constantine, in his letter to Macarius, bishop of Jerusalem, spoke of "the token of that holiest passion," ( long been hidden under the ground and had now been found. ${ }^{170}$ Later, Cyril, in his letter to Constantius, remarked that the Cross was found in Constantine's time. ${ }^{171}$ Cyril believed that during the excavation work of uncovering the tomb, the Cross, or at least a piece of wood believed to be the cross, was discovered. ${ }^{172}$

\footnotetext{
168 Catech. 14.9; see also Kalleres, "Cultivating True Sight at the Center of the World," 441.

${ }^{169}$ Catech. 10.9, 13.39, 14.22; see also Walker, Holy City, 252.

${ }^{170}$ Euseb. Vit. Const. 3.30; see also Drijvers, Cyril, 20.

${ }^{171}$ Epist. ad Const. 3; see also Drijvers, Cyril, 19.

172 Drijvers, Cyril, 19, 26; Walker, Holy City, 256-57.
} 
The Cross of Christ represented a multitude of themes for Cyril that all proved essential for Christians. It was the foundation for Christian faith, the ground for salvation, the end of sin, the source of life, illumination, and redemption in the world. He argued that the Cross was the very crown of Christ, and that the glory of the church could only be found through the Cross. ${ }^{173}$ Not only was the Cross a mark of the finished events of the past for Cyril, but it was also the sure sign of Christ's second coming, and therefore it was the promise of the future for Christians. ${ }^{174}$ Golgotha and the Cross were two essential parts of the story of Christ's death. He was crucified on the Cross, which was mounted on the rock of Golgotha. Cyril discusses how the cross and Golgotha were two themes that were forever linked, two parts of the story of redemption. He claimed these fragments had already "filled almost the whole world." ${ }^{175}$ Cyril never once mentioned the cave of the resurrection. Eusebius and Cyril were focused on completely different aspects of the theological implications of the Holy Sepulchre, which was the church of Christ's death and resurrection. Eusebius only had interest in the resurrection, and Cyril focused his attentions squarely on the death of Christ.

While Cyril never mentioned the cave of the resurrection, he did, however, mention the tomb of Christ. Eusebius referenced the tomb of Christ as a means of discussing Christ's resurrection, never focusing on his death. Cyril, however, focused on the tomb of Christ as a sure sign of Christ's death. Cyril argued that Jesus "was truly laid

\footnotetext{
${ }^{173}$ Catech. 4.9, 13.1, 13.4, 13.19, 13.20, 13. 22, 13.37, 13.38. see also Drijvers, Cyril, 14-26; Walker, Holy City, 256-59.

${ }^{174}$ Catech. 15.22; see also Drijvers, Cyril, 14-26; Walker, Holy City, 256-59.

${ }^{175}$ Catech. 4.10, 10.19, 13.4, 13.39; see also Drijvers, Cyril, 26; Walker, Holy City, 259.
} 
as a man in a tomb. ${ }^{176} \mathrm{He}$ drew connections to Christ being buried in a rock ( $\left.\pi \dot{\varepsilon} \tau \rho \alpha\right)$, which he used metaphorically to discuss the cave that made Jesus's tomb. Yet, for Cyril, the symbol of the rock was multifaceted, not only did it represent Christ's tomb, it also was the rock of Golgotha upon which Jesus died. Cyril linked the rock and the tomb together as one idea, for both were joined together in the Holy Sepulchre. ${ }^{177}$

In Cyril's time, the rock of Golgotha had a split down the middle. According to the gospel of Matthew, "the rocks were split" at the moment of Jesus's death and Cyril argues in his lectures that the power of Christ's death can still be seen on Golgotha. ${ }^{178}$ This split represented the power of Christ in his death. He was laid as a man in a tomb of rock, "but the rocks were rent for fear of him." 179 There were three major witnesses to Christ's death, according to Cyril, "The wood of the Cross is a witness;... Golgotha...is a witness; the holy tomb is a witness and the stone still lying there." 180 Together these three witnesses were a sure sign that Christ had died and that the story of the salvation for humankind was completed. All three witnesses came together to create the unified message of the death of Christ in the Holy Sepulchre which housed the wood of the Cross, the tomb of Christ, and the rock of Golgotha. These three elements in one church made the Holy Sepulchre the most important site in the entire world. There was no doubt about its centrality, and as a result in Cyril's thoughts Jerusalem became the central city in the Christian world.

\footnotetext{
176 Catech. 4.11; see also Walker, Holy City, 266-67.

177 Catech. 13.38, 13.55, 14.22; see also Walker, Holy City, 266-67.

178 Catech. 4.12; Mt. 27:51; see also Walker, Holy City, 267.

${ }^{179}$ Catech. 4.12; see also Walker, Holy City, 267.

${ }^{180}$ Catech. 14.22; see also Walker, Holy City, 270.
} 


\section{3: The Bordeaux Pilgrim on the Triad}

The account of the Triad of churches provided by the Bordeaux Itinerary noticeably contrasts with the works of Eusebius and Cyril. As educated leaders and bishops of the church, both Eusebius and Cyril spent a significant amount of time and energy developing their arguments and theological views. Compared to these writers, the Bordeaux pilgrim's account of Jerusalem and the Triad of Churches is sparse at best. ${ }^{181}$

The Bordeaux pilgrim references four churches in the itinerary. These include the Holy Sepulchre, the Eleona, the Nativity, and finally Mamre. ${ }^{182}$ While he may have visited other churches, it appears that Constantine's four basilicas were a high-point of his trip. The pilgrim went out of his way to visit every Constantinian basilica, even the still incomplete Holy Sepulchre. ${ }^{183}$ These basilicas must have been truly memorable for them to have made as strong an impact on the pilgrim as they did.

The entire passage from the Bordeaux Itinerary concerning the Church of the Nativity is only two sentences long: "Two miles further [from the tomb of Rachel, six miles along the road from Jerusalem to Bethlehem], on the left side, is Bethlehem, where our Lord Jesus Christ was born. A basilica has been built there by the orders of

\footnotetext{
${ }^{181}$ The Pilgrim's account of the Church of the Nativity is only three lines long; It. Burg. 598.5-598.7. Similarly, the Pilgrim's account of the Eleona church is also only three lines long; It. Burg. 595.4-595.6. The pilgrim's account of the Holy Sepulchre church is the longest of the three passages, but, at five lines, it is still very brief when compared to the accounts of Eusebius or Cyril; It. Burg. 593.4-594.4.

${ }^{182}$ It. Burg. 593.4-594.4, the Holy Sepulchre; It. Burg. 595.4-596.1, the Eleona at the Mount of Olives; It. Burg. 598.6-598.8; the Church of the Nativity in Bethlehem; and finally It. Burg. 599.4-599.6, the Mamre. ${ }_{183}$ Armstrong, "Constantine's Churches," 13-16; Crowfoot, Early Churches in Palestine, 9-15; Drake, "The Return of the Holy Sepulchre," 263-67; Holum, "Hadrian and St. Helena," 70; Lenski, "Empresses in the Holy Land," 113-25; Magness, The Archaeology of the Holy Land, 323-33; Patrich, "The Early Church of the Holy Sepulchre," 101-6; Tsafrir, Ancient Churches Revealed, 1-10; Walker, Holy City, 202-17; Wharton, "The Baptistry of the Holy Sepulcher," 313-25; Wilkinson, "Constantinian Churches in Palestine," 23-27.
} 
Constantine." ${ }^{184}$ The description, compared to those offered by bishops, seems simple at best. The pilgrim states that Jesus Christ was born in Bethlehem, and that this was the site of a basilica commissioned by Constantine, two pieces of information discussed by both Eusebius and Cyril. However, the fact that the pilgrim decided to journey to this site at all and chronicle it in his itinerary indicates the value of the place. The pilgrim spent a great deal of time, relative to the overall scope of the itinerary, in Jerusalem visiting various sites of significance in biblical history. ${ }^{185}$ While in Bethlehem, the pilgrim only referenced two sites of importance before continuing the pilgrimage, the Church of the Nativity, and a tomb of several figures of biblical history. ${ }^{186}$ Compared to Jerusalem, it seems that Bethlehem was not filled with many different locations of significance to the pilgrim, yet the Church of the Nativity garnered the pilgrim's interest enough to leave Jerusalem. Bethlehem, then, was a place to visit, not a site of political or theological debate.

The pilgrim's account of the Eleona at the Mount of Olives is very similar to the account of the church of the Nativity. He says that "there by the orders of Constantine a basilica has been built. Not far from there is the small mountain which the Lord ascended to pray, when he took Peter and John with Him, and Moses and Elias were seen." 187 The second sentence provides historians with some difficulty. The original Latin, "Inde non

\footnotetext{
${ }^{184}$ It. Burg. 598.5-598.7.

185 The entire Jerusalem section of the itinerary composes fifty lines in the itinerary manuscript; It. Burg. 589.4-596.3. The Bethlehem section, in comparison is much shorter in the itinerary, only four lines; It. Burg. 598.6-598.9.

186 It. Burg. 598.8-598.9.

${ }^{187}$ It. Burg. 595.4-596.1: Inde ascendis in montem Oliveti, ubi Dominus ante passionem apostolos docuit: ibi facta est basilica iussu Constantini. Inde non longe est monticulus, ubi Dominus ascendit orare et apparuit illic Moyses et Helias, quando Petrum et Iohannem secum duxit.
} 
longe est monticulus, ubi Dominus ascendit orare et apparuit illic Moyses et Helias, quando Petrum et Iohannem secum duxit, " could be translated several ways, with very different implications. Walker, in his account of the Mount of Olives, believes that the Bordeaux pilgrim made a mistake. He argues that the Latin word used, monticulus, would best be translated as a "hillock," which in this context is the summit of the mountain. According to this translation, the pilgrim was claiming that the transfiguration occurred on the Mount of Olives, which is not true according to the Bible. ${ }^{188}$ The biblical event that Christians believe occurred on the Mount of Olives was Christ's ascension into heaven, recorded in Acts 1:6-11. However, according to this translation, the pilgrim mistook the site for another biblical event on a separate mountain, the transfiguration, which occurs earlier in Jesus' life in Matthew 17:1-8. ${ }^{189}$ In this passage, Jesus took Peter and John with him to the top of an unknown mountain and was visited by the spirits of Moses and Elijah, and later was himself transfigured with the glory of God. This event is a completely different event from Christ's ascension taking place on a different mountain.

There is little connecting these two events other than the fact that both occur in the New Testament, on a mountain, and involve Jesus. Walker argues the Bordeaux pilgrim would have heard that the summit of the Mount of Olives was a site of great significance for Christians, but would not have fully understood the history of the site and would then have mistakenly believed the summit of the mountain to be the site of the

\footnotetext{
${ }^{188}$ It. Burg., 595.6; Walker, Holy City, 213-14.

${ }^{189}$ It. Burg., 595.6.
} 
transfiguration, not the ascension. ${ }^{190}$ The pilgrim might have heard stories about two separate events on biblical mountains and combined them. ${ }^{191}$ The pilgrim discussed how Christ "ascended to pray" and was later transfigured. He might have thought the story of the ascension was not Christ ascending to heaven, but Christ ascending to the summit of the mountain, where the basilica had been built, to receive God's blessing during the transfiguration. ${ }^{192}$ If Walker is correct then the contentions between Eusebius and Cyril over the Mount of Olives, might only have further confused the pilgrim as to why the Eleona church was built around a cave, when the summit marked the important event.

There might be some confusion on this issue, however. The pilgrim could be using the word monticulus to refer to a second, unnamed mountain nearby. The pilgrim might mean in this passage that he was on the Mount of Olives and that there is another mountain not too far away (inde non longe est) where the transfiguration happened. Countering this, Walker argues that the mountain commonly believed to be the site of the transfiguration in the fourth century was Mt. Tabor, which was in Galilee. Both Eusebius and Cyril discuss Mt. Tabor as the possible site of the transfiguration. Cyril states categorically, without hesitation, that Mt. Tabor was the site of Christ's transfiguration. ${ }^{193}$ Eusebius, however, never explicitly located the site of the transfiguration, rather he only references Mt. Tabor as a possibility. ${ }^{194}$ Mt. Tabor lies approximately ninety miles away from the city of Jerusalem, which would be far too great a distance for the pilgrim to

\footnotetext{
${ }^{190}$ It. Burg., 595.6; Walker, Holy City, 213-14.

${ }^{191}$ Walker, Holy City, 213-14.

192 It. Burg., 595.6.

193 Catech. 12.16; Jerome Ep. 46.12, 108.13; see also Walker, Holy City, 145.

${ }^{194}$ Euseb. Comm. In Ps. 88.13; see also Walker, Holy City, 146.
} 
consider the mountain "not far." 195 There is also precedent for the pilgrim using the Latin word monticulus to reference a hill and not a mountain. The pilgrim later in the itinerary uses the word monticulus to reference the hill on which the rock of Golgotha rested, which was also not a separate mountain. ${ }^{196}$

While it is possible that the Bordeaux pilgrim believed that the transfiguration did not occur on the Mount of Olives, and instead on some other, unmanned mountain, close to the Mount of Olives, this seems unlikely. If that was the case, it raises more questions than it answers. First, if pilgrim believed the transfiguration occurred on another mountain, it is very odd that the pilgrim would never mention the ascension at all. Both Eusebius and Cyril credited the ascension as a site of great biblical significance and the reason for the Eleona church, one of the central moments in the gospel. If the pilgrim was aware that the ascension and transfiguration were two separate events on separate mountains, why did he fail to mention that the Eleona church was designed to honor the site of Christ's ascension into heaven? It is possible that the pilgrim thought that the ascension did not occur on the Mount of Olives, or that it did not even occur to the pilgrim to think about the ascension, but if the latter possibility is correct, that would mean that he provided no reason for the Eleona church to have been built there. The pilgrim explicitly mentioned biblical reasons for the other Constantinian basilicas, if the Eleona church was as important as its inclusion in the itinerary implies, there should be a biblical event that the church honors, yet the only biblical event the pilgrim mentions is the transfiguration. Finally, if the pilgrim believed the transfiguration occurred on another

${ }^{195}$ It. Burg., 595.6.

${ }^{196}$ It. Burg. 593.4. 
mountain, why did the pilgrim not go visit that mountain at some point, especially it if really was not far off (inde non longe est)? The pilgrim goes out of the way to visit each of Constantine's basilicas, thus it seems likely that the site of the transfiguration would be worth mentioning, especially if it was so close. Overall, it seems much more likely that the pilgrim was simply mistaken about the biblical significance over the Mount of Olives.

The pilgrim was most likely unfamiliar with the biblical history of the Mount of Olives and was either misinformed by a guide about the history of this mountain, did not ask about the history of the mountain, or simply did not care to learn. Whatever its cause, such unfamiliarity illustrates that church leaders like Eusebius and Cyril could have a very different knowledge base than those individual Christians who may have visited the Holy Land. Both Eusebius and Cyril developed detailed arguments concerning the cultural and theological significance of Christ's ascension on the Mount of Olives, however, the nameless pilgrim sees a beautiful church on an important mountain and for one reason or another misinterprets the entire reason for the existence of the church. This mistake demonstrates that the precise biblical history of the Church of the Eleona on the Mount of Olives was much less significant to the Bordeaux pilgrim than it was to either Eusebius or Cyril. Whatever the reason for the pilgrim's confusion, to the Christian on the ground, the Mount of Olives was a site of importance and one that demanded attention, even if the reason for visiting it could be made in error.

All three of our sources discuss the centrality of the Holy Sepulchre in Palaestina. Both Eusebius and Cyril describe the church as honoring one of the most important events in Christ's life. As noted above, where they differ is that Eusebius credits the resurrection of Christ as the aspect of the Holy Sepulchre worth discussing, whereas Cyril 
believes the death of Christ was the central message of both the church and the Bible.

The Bordeaux pilgrim also recognized the significance of the Holy Sepulchre. In 333, when he visited Jerusalem, the Holy Sepulchre was not yet finished. Its consecration, and Eusebius's speech praising it, would not occur for another two years. ${ }^{197}$ Walking through Jerusalem, the pilgrim describes the incomplete church:

On the left side is the hill of Golgotha where the Lord was crucified. About a stone's throw from thence is a vault wherein His body was laid, and resurrected on the third day. There, at present, by the command of the Emperor Constantine has been built a basilica, that is to say, a church of wondrous beauty, having at the side reservoirs from which water is raised, and a bath behind in which infants are washed. ${ }^{198}$

Even in such a short passage, the Bordeaux pilgrim brings up many interesting points.

The pilgrim's account of the Holy Sepulchre is more detailed and longer than the account of any of the other churches, both in terms of describing the physical building and in terms of the biblical history of the church. Compared to his brief accounts of the other churches, the pilgrim's description of the Holy Sepulchre - the oldest by an eyewitness - is lengthy and grand. Not only does he reference the basilica itself, saying that it is of "wondrous beauty (mirae pulchritudinis)," he also describes reservoirs in the back and a bath used to wash, most likely baptize, infants. ${ }^{199}$ The Holy Sepulchre must have made a significant impression on the pilgrim to justify this amount of detail.

\footnotetext{
${ }^{197}$ Drijvers, Cyril, 16.

198 It. Burg. 593.4-594.4.

${ }^{199}$ It. Burg. 594.2-4; see also Wharton, "The Baptistry of the Holy Sepulcher." It seems likely that the pilgrim had some personal interest in healing springs and children, as many of the sites referenced throughout Jerusalem discuss similar themes, for example: It. Burg. 588.4 mentions where Jesus met the Samaritan woman at the well, It. Burg. 586.1-2, 596.7-10 reference wells or fountains that are helpful for healing and fertility, It. Burg. 595.1 references children carry branches during Palm Sunday, among other references to women and childbirth throughout the itinerary. See also Douglas, "A New Look at the Itinerarium Burdigalense," 325-7.
} 
The Bordeaux pilgrim also spends time discussing the biblical history associated with the Holy Sepulchre. On his journey through Jerusalem, the pilgrim walked past the house of Pontius Pilate and mentioned this as the spot where Jesus was tried before his execution. ${ }^{200}$ Following that event, the pilgrim referenced the rock of Golgotha. The final aspect of the history of the Holy Sepulchre that the pilgrim references is the vault where Jesus was buried and raised from the dead on the third day. The pilgrim appears wellinformed about the significance of the Holy Sepulchre as he, unlike either bishop, conveys the entire history upon which the church was built. Eusebius only discussed the resurrection and left out the rock of Golgotha and the death of Christ, whereas Cyril ignored the resurrection to focus on the significance of Golgotha and the death of Christ. The pilgrim, then, offers a fuller description of the significance of Constantine's great basilica than either of the two church leaders, who were both more interested in using the church to further their individual agendas. ${ }^{201}$

\section{Conclusion}

Eusebius, Cyril, and the Bordeaux pilgrim all discuss three significant churches built by Constantine in Palaestina. Eusebius linked these three churches together thematically through the caves that all shared an important part in the biblical story of Jesus Christ. While Eusebius would never directly refer to these churches as the Triad,

\footnotetext{
${ }^{200}$ It. Burg. 593.1-3

${ }^{201}$ The pilgrim's account of the Holy Sepulchre also makes no reference to the fragments of the cross at all. It seems unlikely that something that Cyril places so much significance on would be ignored completely by the pilgrim, especially if the fragments were as central in the layout of the Holy Sepulchre as Cyril seems to imply. It seems that Cyril could have exaggerated the importance the cross played at that time, or that the fragments were not uncovered during the excavation of the church at all, or that the fragments of the cross were not displayed until after the pilgrim's visit to the church, since its construction had not been finished. The fragments might have been discovered later, as Cyril wrote his lectures almost two decades after the pilgrim's journey, or maybe the story of the discovery of the cross was completely made up.
} 
historians later applied the name to the churches that Eusebius drew together. Each of our sources has a very different way of understanding and interpreting the significance of these churches. For Eusebius, the Triad was a way to draw Christian attention away from Jerusalem. Eusebius was the bishop of Caesarea, the political and religious center of Palaestina. The growing influence that Constantine's Holy Land policy gave to Jerusalem threatened Eusebius's position. In his discussion of Constantine's churches, he worked carefully to draw Constantine's interests away from Jerusalem exclusively. Eusebius's earlier writings were very critical of the city of Jerusalem, but these changed after the rediscovery of the tomb of Christ and the building of the Holy Sepulchre church. Even Eusebius recognized and praised the cultural and theological implications of Constantine's Holy Sepulchre.

Cyril, the bishop of Jerusalem, held very different opinions on the Triad of churches than Eusebius. While Eusebius worked to draw Christian interests away from Jerusalem, Cyril did what he could to keep interests squarely on his city. He never discussed the three caves that united Eusebius's Triad. The Church of the Nativity was not related to the cave where Jesus was born, instead Cyril drew attention to the manger. The Eleona on the Mount of Olives was not built around the cave where Jesus taught his disciples hidden truths, but the summit of the mountain where Jesus ascended to heaven. The Holy Sepulchre was not centered on the cave that was Christ's tomb, but instead the rock of Golgotha, which symbolized Christ's death. When discussing the Holy Sepulchre, Eusebius focused his attention on the resurrection of Christ, which was symbolized by the cave of the resurrection. Cyril, however, focused his attention on the symbols of Christ's death, the wood of the cross, the rock of the tomb, and the rock of Golgotha. Cyril even 
went as far as to claim both Bethlehem and the Mount of Olives as part of Jerusalem's cultural heritage, not separate entities that competed for attention.

The Bordeaux pilgrim, on the other hand, was more interested in experiencing the sites of Jerusalem and Constantine's basilicas. ${ }^{202}$ The pilgrim's interests varied widely between many different topics while traveling through Palaestina. While we will never know if the Triad of Churches were the main interest for the pilgrim, what we do know is that the he carefully planned the itinerary to visit each of Constantine's basilicas. His account of two of the basilicas was very brief, only mentioning that they were ordered by Constantine and briefly describing the biblical event that the churches commemorated. The account of the Eleona was even incorrect, detailing a separate event that occurred on a separate mountain. The itinerary puts special focus on the Holy Sepulchre, however, which goes to show that Constantine's desire to make it a building beautiful beyond all others must, on some level, have been reached. The pilgrim was most likely not a church leader, but instead a Christian on the ground level, as it were. While political and theological differences occupied the two bishops, and, no doubt, even the emperor, they do not appear to be the source of concern for Christians like the Bordeaux pilgrim.

202 Drijvers, Cyril, 15. Drijvers even argues that it is possible that these sites only ever became sacred for Christians because Constantine built these churches. 


\section{Chapter 4}

\section{Palaestina and Jerusalem}

The previous chapter discussed how Eusebius, Cyril and the Bordeaux pilgrim understood and interpreted the Constantinian churches of the Nativity in Bethlehem, the Eleona at the Mount of Olives, and the Holy Sepulchre in Jerusalem, which historians have come to call the Triad of Churches. ${ }^{203}$ In this chapter, I will take a step back from these churches and focus more broadly on how these three sources presented Jerusalem and the rest of Palaestina. For Eusebius, the rich biblical history throughout Palaestina made the land historically important and worthy of the Christian interests that Constantine was promoting. ${ }^{204}$ However, Eusebius did not feel that this rich history led to any theological significance for the city of Jerusalem or the rest of Palaestina at all. While his views would change slightly by the end of his life, in his earlier writings he believed strongly that God was not bound to any land and therefore no location should be held holier than any other. ${ }^{205}$

Cyril, on the other hand, viewed Jerusalem as the most important city in the world. For Cyril, the city of Jerusalem itself was holy. Simply living within the city, or even visiting the holy sites, granted the Christian a spiritual closeness to God. The sites of the life of Jesus Christ throughout Palaestina, and especially in the city of Jerusalem, granted Christians the ability to see and directly experience the life of Christ, and

\footnotetext{
${ }^{203}$ Drijvers, Cyril, 15-21; Walker, Holy City, 184-98.

${ }^{204}$ For example, see Euseb. Ecc. Hist. and the Onomasticon.

${ }^{205}$ For example, see Euseb. Dem. Ev. 5 where he argues that God is not held in the physical, the holy spirit

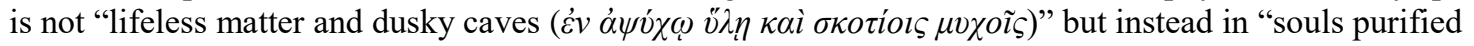
and prepared with rational and clear minds ( also Walker, Holy City, 75.
} 
therefore grow closer to him and salvation. All other Christians throughout the world were left with no other choice than to hear the biblical stories; they could not experience them. Together, all these elements made Jerusalem in a very real and physical sense, the "very center of the world.",206

The Bordeaux pilgrim, on the other hand, did not write about Palaestina and Jerusalem as a Church father. Instead, as a traveler, the pilgrim was interested in experiencing the power and history of the land. For the pilgrim, Palaestina was a land rich with history, both Jewish and Christian. His itinerary reveals how the region's Jewish history had been incorporated into the contemporary Christian tradition to make Palaestina, and Jerusalem in particular, a Christian Holy Land. Yet, for the pilgrim, there was more to Palaestina than just its history. His focus on the miraculous elements of Palaestina showed how the land itself had power which separated the Holy Land from the rest of the Roman Empire and made the journey to Palaestina worthwhile.

\section{Section 1: Eusebius}

Eusebius of Caesarea was a historian who worked hard to recount the history of not only the church, but also his home province of Palaestina. While the Ecclesiastical History spanned much of Church history throughout the Roman world, he would later supplement this work with an account of the Palestinian Martyrs during the great persecution through which he lived. The clearest example of his historical focus on Palaestina in his writings, however, comes from his work the Onomasticon. In his

\footnotetext{
${ }^{206}$ Catech. 5.10, 10.19, 13.38-9. Cyril calls places Jesus interacted with during the incarnation "Holy Places"; Catech. 10.19, 13.38-9, 14.22-3 Cyril has three extended accounts of physical witnesses to Christ; Catech. 13.28 Christ's death on the Cross made Golgotha/ Jerusalem the very center of the world; see also Walker, Holy City, 37, and Kalleres, "Cultivating True Sight at the Center of the World," 451.
} 
preface, Eusebius carefully outlines several of the major intentions of this work. He desired to translate the Hebrew names from the Jewish Torah into Greek, compile a list of all of Judaea, focusing on the lands of the twelve tribes, describe the city of Jerusalem and the temple, and create a cohesive list of all the cities and villages mentioned in the Bible. Essentially, Eusebius was taking the ancient history of the region of Palaestina and crafting a lens to impose that history onto contemporary Palaestina. ${ }^{207}$ As discussed in chapter 2.2, the Onomasticon was an encyclopedic list of the places mentioned in the Bible. It was not a geographic overview of the entire holy scripture; Eusebius was focused solely on Palaestina. ${ }^{208}$ In total, there are almost a thousand names provided in the Onomasticon, with most of the focus going to the Old Testament. While it might be useful to study in detail the individual entries, ${ }^{209}$ one gets a much better understanding of the Onomasticon when looking at it as a whole.

Eusebius did not take inspiration for his geographical survey of Palaestina either from Ptolemy's mathematical geography nor Strabo's descriptive geography. He rarely mentioned Palaestina's geographical or physical nature in the Onomasticon. Instead, he wrote the Onomasticon as an instrument to help his reader understand the scripture and elucidate the biblical narrative. The alphabetical presentation of the work shows that Eusebius experienced Palaestina from the perspective of a scholar, with easily

\footnotetext{
${ }^{207}$ Euseb. Onom. 2.3-17; see also Stenger, "Eusebius and the Representation of the Holy Land," 384-92.

${ }^{208}$ Wolf, "Eusebius of Caesarea," 74.

${ }^{209}$ For example, in Euseb. Onom. 42.10-14 on the entry on Bethlehem, Eusebius makes no reference to the New Testament at all. The birth site of Jesus, where Constantine would later build one of the Triad of churches, has no reference to Jesus. This absence is glaring and shows that at the time of writing the Onomasticon, Eusebius had little interest in discussing the theological implications of Palestine. The Onomasticon was much more focused on events of the Old testament, barely even referencing events of Jesus' life; see also Walker, Holy City, 42; Wolf, "Eusebius of Caesarea," 74.
} 
identifiable information, rather than from the perspective of a traveler or pilgrim. If

Eusebius intended the Onomasticon as a pilgrim's guidebook, it would be reasonable for him to organize the material as an itinerary or in a more descriptive fashion, rather than as an encyclopedia, which was more scholarly in nature. ${ }^{210}$ While there is historical debate over Eusebius's intentions in writing the Onomasticon, ${ }^{211}$ it seems clear that Eusebius wrote his geographical survey of Palaestina from the perspective of a historian. Eusebius was an active writer throughout his long life and experienced many dramatic political and religious changes. It makes sense that his opinions, and therefore his writings, would change as he changed. Throughout his life, Eusebius's opinions on the significance of the city of Jerusalem and Palaestina would also change. In Eusebius's earlier works his opinions were much more historical in nature with little emphasis given to the religious significance of the city of Jerusalem. Overall, Eusebius displays little of the negativity towards Jerusalem that he would later display once Constantine started his development of Palaestina. As Eusebius mentions in his preface to the Onomasticon, one of his goals was to include Jerusalem and the temple in his survey of the land of Palaestina. ${ }^{212}$ Eusebius references the city of Jerusalem, but in this passage, he makes no reference to Jesus. ${ }^{213} \mathrm{He}$ also made note of multiple points within the city that held

\footnotetext{
${ }^{210}$ Stenger, "Eusebius and the Representation of the Holy Land," 392-6; Wolf, "Eusebius of Caesarea," 74.

${ }^{211}$ Historians have taken several different approaches to understand the Onomasticon. Two themes that recur throughout the scholarship are that Eusebius intended the work as a travel guide to help a pilgrim move through the holy land, and another that argues that Eusebius was working to imprint Christian values on top of the Jewish geography and history of Palestine. Wolf suggests that Eusebius intended the Onomasticon as a proto-pilgrimage guide that would equip its readers with a useful guidebook and resource to help identify important places to visit and worship as well as a means of helping the pilgrim move from one place to another. Stenger, however, argues that the Onomasticon was not designed as a travel guide for a pilgrim, but instead as a reference to illuminate the religious history and significance of any location within Palestine for the Christian to be able to experience God's salvation through the power of space.

${ }^{212}$ Euseb. Onom. 2.3-17.

${ }^{213}$ Euseb. Onom. 106.
} 
significance, including both Gethsemane and Golgotha. ${ }^{214}$ Also, in the Ecclesiastical History, Eusebius gave special notice to the history of the Jerusalem church multiple times. He chronicled the bishops of Jerusalem up to the point of Hadrian, and later updated this list once the Jews were exiled from Jerusalem under Hadrian and Gentile bishops were appointed in their place. Finally, Eusebius referenced Jerusalem as the throne of James, the brother of Christ. ${ }^{215}$ He presents Jerusalem in a rather positive light in these accounts, even saying that the bishops of Jerusalem received the knowledge of

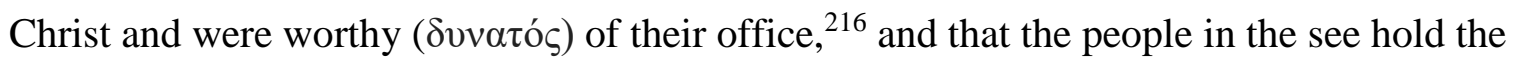

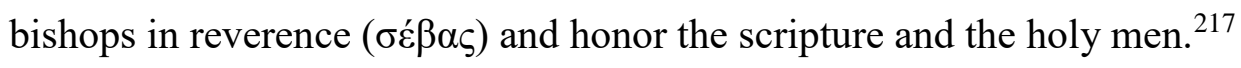

Before the fourth century, Jerusalem and Caesarea were much more amicable. Eusebius even mentions several points where the bishops of the two cities worked together in helpful collaboration. Walker argues that the tensions between Caesarea and Jerusalem only grew in the fourth century, after Eusebius became the bishop of the former in $313 .{ }^{218}$ After these references in the Onomasticon and Ecclesiastical History, Eusebius never again referenced Jerusalem directly until he quotes a letter from Constantine to the bishop of Jerusalem in his Life of Constantine. Walker believes that after the great persecution, the Jerusalem church desired to hold more authority in

\footnotetext{
${ }^{214}$ Euseb. Onom. 74.16-21. See also Kalleres, "Cultivating True Sight at the Center of the World," 432.

${ }^{215}$ Euseb. Hist. Ecc. 4.5.1-5, 5.12.1-2, 7.19; see also Walker, Holy City, 55.

${ }^{216}$ Euseb. Hist. Ecc. 4.5.2. "In the estimation of those who were able to judge, they were well-approved and

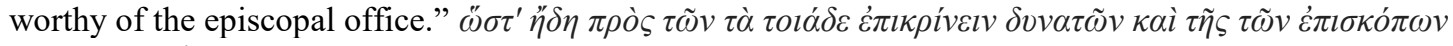

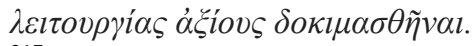

${ }^{217}$ Euseb. Hist. Ecc. 7.19.

${ }^{218}$ Euseb. Hist. Ecc. 4.5.1-5, 5.12.1-2, 7.19; see also Walker, Holy City, 55-6.
} 
Palaestina, and this caused tensions between Caesarea and Jerusalem that would shape much of Eusebius's subsequent writings. ${ }^{219}$

Although Eusebius held a comparatively positive view of the city of Jerusalem in his early writings, this did not mean that he believed the city held any theological significance for Christians. For Eusebius, no place could be considered inherently holy. The scripture of the Bible was the only thing that would link man and God. There was no place that could bridge the gap and bring people closer to God. No Christian could ever gain salvation from physical creation. Eusebius makes this sentiment very clear in his Preparation for the Gospel, where he argues that God is not held in the physical; the

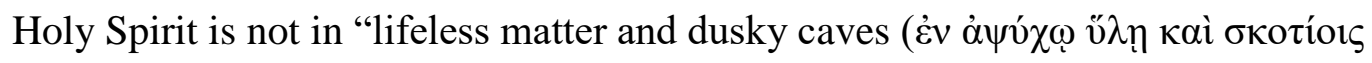

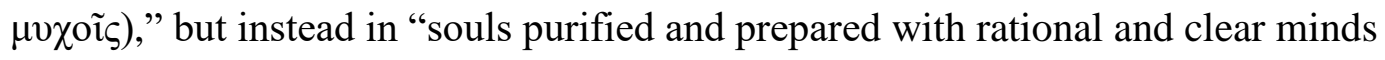

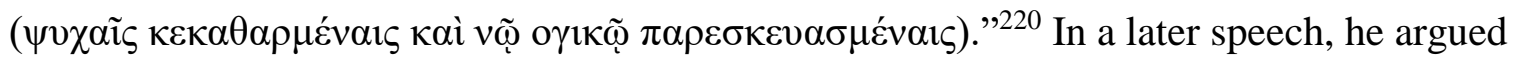
that someone trying to reach God through the physical world is like someone trying to reach the sun through digging in the mud and muck..$^{221}$

As an historian, Eusebius understood that the city of Jerusalem held great historical importance for Christians. While any spiritual significance the city once held during the Old and New Testament was now gone after God's judgment, the city was still the site of many of the central events from the life of Jesus Christ. Many holy events occurred within the walls of the city, and therefore it was possible for the sites of Christ's life to act as evidence of Christ's salvation. While these sites could not bring someone to

\footnotetext{
${ }^{219}$ Walker, Holy City, 55-6.

${ }^{220}$ Euseb. Dem. Ev. 5.29.

${ }^{221}$ Euseb. Sep. Chr. 13.6.
} 
salvation, they could inspire a Christian to seek God through the testimony they provided to the holy events that occurred there. While individual Christians might gain some benefit from studying the historical events that occurred in Jerusalem and the life of Jesus, the city itself had been judged and condemned by God. Unlike Judaism in the past, Christianity was not bound to a specific place. Places were of no interest to God and had no significance to Christians. God desired and commanded worship that was not bound to

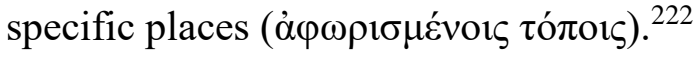

However through his exposure to Constantine at the end of his life, Eusebius would begin to grow more accepting of the holiness of specific sites of Christ's life. In his speech On Christ's Sepulchre, Eusebius argued that the resurrection was the most holy event of all human history, and the site of Christ's tomb was now connected to the holiness of his resurrection, and therefore could be considered "holy" by its historical association. ${ }^{223}$ However, while Eusebius acknowledged that the site of Christ's resurrection was holy, he never gave any specific importance to the city itself. Eusebius would resolve these tensions concerning the city of Jerusalem through his study of the entire region of Palaestina. As we will see, Eusebius worked hard to create a theological view of Palaestina that both admitted the power of the gospel narrative that occurred throughout the land, but simultaneously downplayed the importance of physical space.

Palaestina saw a surge of religious activity under Constantine. Christian interests in the region grew considerably with Constantine's Holy Land policy and funding of churches. From as early as the second century, many Christians venerated the burial sites

\footnotetext{
${ }^{222}$ Euseb. Dem. Ev. 1.6.40. See also Walker, Holy City, 45-6.

${ }^{223}$ Euseb. Sep. Chr. 15.9. See also Walker, Holy City, 45-6.
} 
of saints and Christians traveled to Palaestina to visit biblical sites, such as the site of Jesus' baptism, or trials at the garden of Gethsemane. ${ }^{224}$ Constantine recognized and honored this practice throughout Palaestina. With the end of persecution, Christianity was permitted to venerate its historical sites and pilgrims journeyed in increasing numbers to Palaestina. ${ }^{225}$ Within a decade of Constantine's development of Palaestina, Helena, Eutropia, and the author of the Bordeaux Itinerary all made pilgrimages to Palaestina. By the fourth century, Monasticism had emerged as a way for many Christians not only experience the holiness of the land of Palaestina, but to completely orient their lives around the land and their faith. Christians monks dedicated their lives to build homes and communities of faith in the land that God had lived. ${ }^{226}$ However, while the wider region soon became the focus of considerable Christian attention, Jerusalem did not resonate with all Christians. The first Christian monk in Palaestina, Hilarion, refused to live near Jerusalem, choosing instead to live in Gaza, which was closer to Egypt than Jerusalem. Hilarion visited Jerusalem only once in his life, believing that God was not confined to the limits of holy places. ${ }^{227}$ Eusebius noted how during the great persecution many Christians throughout the Palestinian countryside continued to worship even when it cost them their lives, even as they distanced themselves from Jerusalem. ${ }^{228}$

\footnotetext{
${ }^{224}$ Euseb. Onom. 74.16-18 (Gethsemane) 58.18-20 (Bethabara, where Christ was baptized); see also Stenger, "Eusebius and the Representation of the Holy Land," 396.

${ }^{225}$ For more information concerning early Christian pilgrimages to Palestine and Jerusalem see: Smith, "My Lord's Native Land," 1-31. Lenski, "Empresses in the holy land," 113-24; Rivers, "Pattern and Process"; Elsner, "Piety and Passion," 411-34; Maraval, "The Earliest Phase of Christian Pilgrimage in the Near East," 63-74.

${ }^{226}$ Robert L. Wilkin, "Loving the Jerusalem Blow: The Monks of Palestine," in Jerusalem: Its Sanctity and Centrality to Judaism, Christianity, and Islam, ed. Lee I. Levine (New York: Continuum, 1999), 241-2.

${ }^{227}$ Jerome, Ep. 58.3; Wilkin, "Loving the Jerusalem Below," 241-2.

${ }^{228}$ Euseb., Mart. Pal. 11.9-11; see also Stenger, "Eusebius and the Representation of the Holy Land," 382.
} 
Eusebius understood this element of Christian identity in the countryside of Palaestina. In his apologetic works, Proof of the Gospel and Preparation for the Gospel, he argued that many religious customs and geographic identity are intimately linked. Territory and ethnic identity are primarily linked in their capacity to evoke religious and cultic memory of the ancestors. Due to this nature of being linked together, many different religions and religious practices are bound to the location and geography of their people. ${ }^{229}$ Eusebius argued that paganism and Judaism are both completely place-bound religions. Jews were bound to Jerusalem because that was the only place they are allowed to perform the required sacrifices. ${ }^{230}$ However, no such restrictions applied to Christians. Eusebius argued restrictions of the country ( $\chi \omega \dot{\omega} \rho \alpha)$, the race ( $\dot{\varepsilon} \theta \vee \circ \varsigma)$, and locality ( $\tau$ ó $\pi \circ \varsigma)$ did not apply to Christians and the Christian community. Since the coming of Christ, God

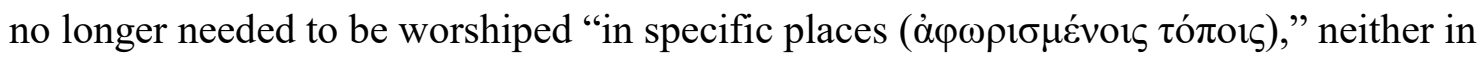
Jerusalem nor in Palaestina, but each Christian could worship God in his own place. ${ }^{231}$ This freedom then allowed Christians to worship God anywhere because the worship of God no longer needed to be "in one corner of the earth ( $\dot{\varepsilon} v \gamma \omega v i$ q $\gamma \tilde{\eta} \varsigma)$ )." God's kingdom, according to Eusebius, was not linked to the land, but to the heavenly kingdom. ${ }^{232}$

\footnotetext{
${ }^{229}$ Johnson (“Greek Ethnicity in Eusebius's 'Praeparatio Evangelica,"” 103) argues that Eusebius does not use terms like pagan in his apologetic work. Instead he only refers to Greeks, Phoenicians, and Egyptians, who each have their own culture, religion, and history. Eusebius, by showing the connections between Greek, Egyptian and Jewish stories, attempts to use this shared Judeo-Christian history and religion to call the Greeks to Christianity.

${ }^{230}$ Euseb. Dem. Ev. 1.3.40.

${ }^{231}$ Euseb. Dem. Ev. 1.6.40.

${ }^{232}$ Euseb. Dem. Ev. 1.6.65, 1.6.73; see also Walker, Holy City, 58.
} 
Eusebius argued that Christianity called to all peoples of all tribes ( $\gamma \varepsilon \dot{\varepsilon} \vee \varsigma)$ and races $(\dot{\varepsilon} \theta v o \varsigma){ }^{233} \mathrm{He}$ argued that all Greeks and all barbarians from every place, city, and land, to all nations under the sun, were free to become Christians. ${ }^{234}$ The Jewish people, being bound by their religion to Palaestina, believed that the land was holy. ${ }^{235}$ In response to this, many of the early Christians, especially in the countryside, rejected the notion that the land could be holy in order to differentiate themselves. Eusebius explains that while Moses promised his people a "Holy Land ( $\dot{\alpha} \gamma i \dot{\alpha} \gamma \tilde{\eta})$," Jesus promised a "much greater land, truly holy and beloved of God not located in Judaea ( $\pi$ o $\lambda \dot{v} \kappa \rho \varepsilon i ́ \tau \tau o v \alpha ~ \gamma \tilde{\eta} \nu, \dot{\alpha} \lambda \eta \theta \tilde{\omega} \varsigma$

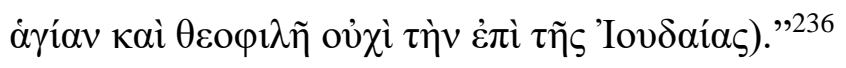

Eusebius's views on the religious insignificance of the land did not stop with the city of Jerusalem. God had not only judged Jerusalem after the failed revolts in 70 and 135 (discussed in Chapter 2), but all of Palaestina. The entire region had no theological significance. For Eusebius, Palaestina "in no way excels the rest [of the earth.]"237 In this way he ultimately distances Christianity completely not only from Jerusalem, but also from Palaestina. However, Eusebius did not make these arguments to attack the region of his bishopric. He loved Palaestina and dedicated much of his life to recording the history, geography, and religion of his homeland. What Eusebius was trying to do here was demonstrate that a Christian in Palaestina was not superior to a Christian in any other

\footnotetext{
${ }^{233}$ Euseb. Praep. Ev. 2.5.2; see also Johnson, "Greek Ethnicity in Eusebius's 'Praeparatio Evangelica,"” 100.

${ }^{234}$ Euseb. Praep. Ev. 1.2.2, 1.4.11, 2.5.2, 4.17.10; see also Johnson, "Greek Ethnicity in Eusebius's 'Praeparatio Evangelica,"' 100.

${ }^{235}$ Euseb. Dem. Ev. 1.2.16, 1.3, 1.3.40, 1.7.4, 1.6.40; see also Kalleres, "Cultivating True Sight at the Center of the World," 432; Walker, Holy City, 61.

${ }^{236}$ Euseb. Dem. Ev. 3.2.10; see also Kalleres, "Cultivating True Sight at the Center of the World," 432; Walker, Holy City, 56-58.

${ }^{237}$ Euseb. Dem. Ev. 1.3.1-3, 3.2.10.
} 
region simply because they lived in the same land where Christ once lived. God called Christians to spread to all corners of the earth and to worship in spirit and in truth. Yet there are still qualities to Palaestina overall that Eusebius found to be significant. As a historian, Eusebius kept addressing the rich history of Palaestina. Throughout much of his historical and apologetic works, Eusebius discussed the fact that Christians in Palaestina wished to experience the truth of the Gospel through their interaction with their history. In the Onomasticon, Eusebius commented on how Christians in Palaestina wished to touch and feel their faith in the world around them. They wanted to interact with Christian history. One of the ways they did this was by praying in Gethsemane where Christ prayed before his death or by bathing in the same spot that John baptized Jesus. ${ }^{238}$ So Eusebius, in his account of the region of Palaestina, both honored and praised the rich history of the region, but at the same time distanced Palaestina from becoming a central location for Christianity.

Eusebius's theology did not allow for Christ to be bound to the land. He believed that Christians were not only allowed but called to spread throughout the entire earth. To promote this view, he, with great care, worked to deliver a spiritual Christ severed from specific location and, instead, present in all elements of the visible world. Eusebius promoted this divine figure to Constantine, using his time in front of the emperor to shift the imperial view of Christ towards one more in line with his own view. ${ }^{239}$ The result was

\footnotetext{
${ }^{238}$ Euseb. Onom. 74.16-18 (Gethsemane) 58.18-20 (Bethabara, where Christ was baptized); see also Stenger, "Eusebius and the Representation of the Holy Land," 396.

${ }^{239}$ For some specifics on Eusebius's imperial speeches to shift the official views of Christ, see Euseb. Sep. Chr. 5.1-5, Euseb. L. Const., 2.1-5, 3.5-4; see also Kalleres, "Cultivating True Sight at the Center of the World," 434.
} 
an imperial view of Christianity that both recognized and honored the holiness of what

Christ did, but was not bound to any specific geographic location.

\section{Section 2: Cyril}

Constantine died in 337, followed shortly after by Eusebius of Caesarea in 339. A little more than a decade later Cyril was appointed bishop of Jerusalem in 350. By the time Cyril started his episcopate the Constantinian basilicas had been completed and Jerusalem had transformed from the provincial city it was in the third century to one of the foremost cities in the Christian world. However, Cyril had a difficult job in front of him. Eusebius had used his time and proximity to Constantine to shape the imperial agenda away from a focus on the real, physical Jesus, and instead Eusebius and Constantine spiritualized Jesus. Eusebius worked to downplay Jesus' human body, made him unbound from any physical location, and emphasized the tomb and the resurrection of Jesus. This had the result of distancing Jerusalem from any ties it might have once had to being called the City of God. While Jerusalem had become a city of great significance for Christians, Eusebius ensured this interest was more historical and less theological in nature. Cyril wanted to transform Jerusalem into the Holy City at the center of the Christian world. He wanted to emphasize the human Jesus, the death of Christ's body, and link this to the city of Jerusalem, showing people that Jerusalem was in a very real sense, the "very center of the world." 240

\footnotetext{
${ }^{240}$ Catech. 13.28; see also Drijvers, Cyril, 156; Kalleres, "Cultivating True Sight at the Center of the World," 434, 451; Walker, Holy City, 254-56. This view of Jerusalem as the center of the world would shape later Medieval maps of the world, primarily the so-called T-O maps. See further, Evelyn Edson, "Maps in Context: Isidore, Orosius, and the Medieval Image of the World," in Cartography and World in Antiquity and the Middle Ages: Fresh Perspectives, New Methods, ed. R. Talbert and R. Unger (Leiden: Brill, 2008), 219-36; Evelyn Edson, "World Maps and Easter Tables: Medieval Maps in Context," Imago Mundi 48 (1996): 25-42; Wesley M. Stevens, "The Figure of the Earth in Isidore's 'De Natura
} 
As discussed in chapter 2.3, our sources for Cyril differ in nature from our sources for Eusebius. While Eusebius was a prolific writer who wrote volumes of work throughout his life covering many different themes and genres, we only really have one significant surviving text from Cyril. Other than a few letters, the only source that remains is Cyril's Catechetical Lectures. He designed his lectures to cater to an audience of pilgrims and new Christians. He filled them with highly visual language to make his lessons appeal to the many different senses of his audience. Standing in the beautifully adorned Holy Sepulchre, which was built to commemorate the death and resurrection of Christ, Cyril called his congregation to "touch and see" the history and reality of Christ's death. ${ }^{241}$ He desired to transform his baptized followers into witnesses of Christ's crucifixion and resurrection. This status would then necessitate the witnesses to defend the real history of the events and grant them a more holy view of Jerusalem, one intricately linked with a real, historical, Jesus, no longer spiritualized and made distant, but a physical person that died and rose from the dead. Standing in front of the rock of Golgotha, upon which Jesus died, Cyril educated his audience to further his views of Jerusalem as the center of the Christian world. ${ }^{242}$

Cyril had a vastly different view of Palaestina and the city of Jerusalem than Eusebius. He believed Jerusalem and the sites from the life of Jesus Christ had real and spiritual powers, which in turn made the sites holy, able to testify to Christians, and this turned Palaestina into the Christian Holy Land. Jerusalem was the first bishopric — the

Rerum,'" Isis 71.2 (1980): 268-77; David Woodward, "Reality, Symbolism, Time, and Space in Medieval World Maps," Annals of the Association of American Geographers 75.4 (1985): 510-21.

${ }^{241}$ Catech. 13.22; see also Kalleres, "Cultivating True Sight at the Center of the World," 431.

${ }^{242}$ Drijvers, Cyril, 154. 
foundation for the position originating with James, Jesus' brother — and the first Christian bishop. ${ }^{243}$ Cyril uses very strong language when referring to Jerusalem and Palaestina. For Cyril, the many places that Jesus interacted with during the incarnation were all "holy places" and other places were "blessed ( $\mu \alpha \kappa \alpha ́ p ı)$ );" he even calls Golgotha in particular "all-holy ( $\pi \alpha v \alpha \gamma$ íos)" on at least two separate occasions. ${ }^{244}$

Cyril argued that the locations from Christ's life were not holy just because they witnessed events themselves, they were holy because they gained real, spiritual power through their association with Jesus. The holy sites could and, according to Cyril's lectures, often did testify the truth of Jesus to Christians and affected their physical lives. ${ }^{245}$ To Cyril, the biblical past, the divinity of Jesus, and the truth of Christianity were not only in the past, but forever present. ${ }^{246}$ The sites from Jesus' life, and Golgotha in particular, are holy in a very real and tangible sense. They witness the truth of Christ and the gospel, they shame, refute, and disprove anyone who questions Christ. He said that Gethsemane called people to remember the swords that were drawn on Jesus, so that they

\footnotetext{
${ }^{243}$ Catech. 4.28, 14.21. In Catech. 14.21 Cyril not only refers to James as the first bishop of Jerusalem and the brother of Christ, he also singles him out as one of the first witnesses to the resurrected Jesus Christ, further cementing the authority James held in the Church. As Drijvers points out, at the Council of Constantinople in 381, in which Cyril played a prominent role, the Church of Jerusalem is called "the mother of all churches" because of the authority of James as the first Christian bishop. Drijvers, Cyril, 155 . ${ }^{244}$ Catech. 1.1, 13.22 here Cyril refers to Golgotha as all-holy ( $\pi \alpha v \alpha \gamma$ íos) in other instances Catech. 5.10, 10.19, 13.38-9 Cyril says the places that Jesus interacted with are themselves holy places. In Catech. 4.10,

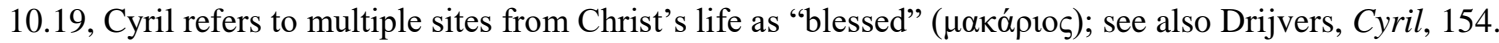
${ }^{245}$ For more on where Cyril discusses the power of holy sites and objects, see: Catech. 1.1, 4.10, 5.10, 10.10, 10.19, 12.31-2, 13.4, 13.22, 13.38-9, 14.22-3, 17.6. In multiple lectures (e.g. Catech. 5.10, 10.19, 13.38-9) Cyril discusses how the incarnate Jesus had made specific spots "Holy Places." These locations include where Jesus healed the blind, lame, and sick, the locations where Christ fed the thousands, where Jesus walked on water, Gethsemane, and the wood of the cross, etc. Cyril lists many different events from Jesus' life and the Gospel narratives that each in their own way have powers and can testify to the power of Christ and the truth of the Gospel.

${ }^{246}$ When referring to Gospel events in his lectures, Cyril frequently discussed how the blessings of Christ

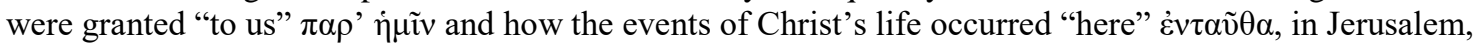
to make the biblical events even more present. For more on this topic, see Walker, Holy City, 332-33.
} 
may believe and not have the eternal swords of hell be drawn on them. ${ }^{247}$ The house of Caiaphas laid in a desolated state with the very rocks hewn apart because Jesus was falsely judged there before his death. These sites were tangible proof of the spiritual world, which called to people, drew them to God, and in a real sense affected their lives. $^{248}$

Cyril believed Palaestina to be the Christian Holy Land, the spiritual center of all the Christian faith. He said that Nazareth, the Archangel Gabriel who appeared to Joseph and Mary in their dreams, and the virgin birth are all witnesses to Christ. ${ }^{249} \mathrm{He}$ argued that Palaestina was now filled with holy sites that gained real, physical powers to testify and witness to Christ. However, he spent much of his lectures not discussing Palaestina in general, but instead, being the bishop of Jerusalem, building up Jerusalem as the center of Palaestina and the Christian faith. As we discussed in the previous chapter, multiple sites that Cyril claims are witnesses to Christ are outside the walls of Jerusalem, like Bethlehem and the Mount of Olives. Although these sites are not physically part of Jerusalem, Cyril made them part of the cultural heritage of the city. ${ }^{250}$ It seems clear that while Cyril was presenting a worldview of Palaestina as a central element for the Christian faith, his major focus was on the city of Jerusalem itself. The centrality of Jerusalem in Cyril's lectures led him to absorb elements of Palaestina that were not physically part of Jerusalem into the influence of the city because of how important he

\footnotetext{
${ }^{247}$ Catech. 13.38.

${ }^{248}$ Catech. 13.38; see also Drijvers, Cyril, 154; Walker, Holy City, 36-7.

${ }^{249}$ Catech. 10.10, 10.19, 12.31, 17.6. Cyril uses these themes multiple times throughout his lectures. He frequently references the sites and events from Jesus' life as a witness to the truth of the Gospel. For more discussion on this topic see Walker, Holy City, 158.

${ }^{250}$ In Catech.16.4, see also Walker, Holy City, 220. This point is developed further in chapter 3.2.
} 
held Jerusalem to be. Consequently, for Cyril, the entire region of Palaestina functioned as a natural extension of the power of Jerusalem.

While the places of Christ's life were important, the city of Jerusalem and the site of Golgotha were especially holy. Cyril says that in Jerusalem "the most honored privileges are ours." ${ }^{251}$ The rock of Golgotha acted as the most holy of witnesses because it testified to the death of Christ. He said that to stand in front of the rock was a powerful witness because "others only hear but we both touch and see." 252 The rock of Golgotha was one of the central themes in Cyril's lectures. Not only were the lectures presented in the Holy Sepulchre in front of Golgotha, but Cyril referenced the stone directly at least a dozen times. In many of these references Cyril praises the stone as a witness to Christ and called it holy. ${ }^{253}$ The power of Golgotha as a witness to Christ was linked to his death on the cross. Cyril drew a special connection between the rock of Golgotha and the cross of Christ, which had fragments spread throughout the world. ${ }^{254}$ The cross was the most powerful, prominent, and glorious Christian symbol. The cross was no illusion. It was a real, surviving relic that was the source of redemption and life, and the end to sin.

Cyril positioned himself to his catechumens as the champion of the lost message of the Gospel. As Kalleres argues, Eusebius and Constantine had created an imperial

\footnotetext{
${ }^{251}$ Catech. 16.4; see also Drijvers, Cyril, 155.

252 Catech. 13.22; see also Kalleres, "Cultivating True Sight at the Center of the World," 431.

${ }^{253}$ Catech. 1.1, 4.10, 4.14-15, 5.10, 10.19, 13.4, 13.22-3, 13.26, 13.28, 13.38-9, 14.6, 16.4. See Catech. 1.1, 13.22 where Cyril calls Golgotha all-holy ( $\pi \alpha v \alpha \gamma i ́(\varsigma)$; in 13.38 Golgotha is listed among many other sites (like Gethsemane, Caiaphas's house, the Mount of Olives, and the fire where Peter warmed himself during Christ's trial) as witnesses to Christ.

${ }^{254}$ In Catech. 4.10 Cyril links the crucifixion and Golgotha, saying Christ was crucified for our sins on Golgotha, and together they act as witnesses to refute anyone who denies Christ's death. Cyril also says that the relics of the cross have been recovered and now the wood of the Cross fills the entire world. For more examples of the wood of the cross, see Catech. 10.19 and 13.4; see also Drijvers, Cyril, 157.
} 
system that favored the tomb over Golgotha, the resurrection over the crucifixion, imperial present over biblical past, and most significantly, Caesarea over Jerusalem. Cyril opposed this shift in imperial focus. He provided his audience with a physical reality of the Gospel that they could interact with. He urged them to touch and see the spot where Christ died. For Cyril, Golgotha was not just one witness among many, it was "the most central point of the earth." 255 The cross of Christ was not just powerless wood, but had the power to save people from the fires of hell. ${ }^{256}$ Cyril used every rhetorical tool in his arsenal during his presentation to help his catechumens gain the true sight of the biblical truth to understand the significance of standing in front of the most important relics in the world within the chosen city of God that stood at the very center of the world. He did not want a spiritualized view of Christ across the empire, he wanted Christians to see Christ as a physical man who died on a cross in Jerusalem, so that they would come to Jerusalem to experience the sites related to the life of Christ. ${ }^{257}$

This powerful view of Jerusalem and Palaestina would be shared by many people during Cyril's time. By the fourth-century, numerous Christians dedicated their lives to live as monks throughout the deserts near Jerusalem. Constantine's basilicas at the Mount of Olives and Bethlehem were particularly effective at drawing the attention of Christian monks from all over the empire. Christian monasticism would last for centuries as many Christians, like Cyril, desired to touch and see the events from Christ's life. ${ }^{258}$

${ }^{255}$ Catech. 13.28; see also Kalleres, "Cultivating True Sight at the Center of the World," 446-51.

${ }^{256}$ Catech. 13.38-9.

${ }^{257}$ Kalleres, "Cultivating True Sight at the Center of the World," 446-51.

${ }^{258}$ Wilkin, "Loving the Jerusalem Below," 242-6. 
For Cyril, the holiness of Jerusalem lay not simply its historical significance. Jerusalem was a holy city, chosen by God, to be his instrument in salvation. Jerusalem in a way was itself divine. He argued that not only was Jerusalem the most preeminent city throughout Palaestina, the Holy Land, it was also the central city in the entire world. This holiness was not simply in the past, but in the present and the future as well. Jerusalem "holds precedence in all good things," Cyril argued. ${ }^{259}$ This significance was not just for the pilgrims who journeyed to Jerusalem, but for all Christians everywhere. In both his lectures and in his letter to the Emperor Constantius, the son of Constantine, Cyril argued that Christ had chosen Jerusalem to be the site for his second coming to earth at the end of times, at which point the physical Jerusalem and the prophesized heavenly Jerusalem will become one. ${ }^{260}$ According to Cyril, these elements combined to create a simple fact: Palaestina was the true Christian Holy Land with Jerusalem, the most important city in the Christian world, at its center. It holds preference over all other cities as the site of the first Christian bishop, the site of the death and resurrection of Christ, the home to the rock of Golgotha and the fragments of the Cross. Jerusalem is the mother church, the promised location for the second coming of Christ, and the site of many different "holy places" within God's Holy Land. For Cyril, Eusebius was wrong to downplay the physical body and death of Jesus. Jesus was not just a spirit separated from all geography, he was a real man, the incarnate Christ, who lived and performed his miracles in the land of Palaestina, which gives the land real spiritual powers, and made Palaestina the Holy Land.

${ }^{259}$ Catech. 3.7; see also Drijvers, Cyril, 155.

${ }^{260}$ Catech. 15.15, Epist. ad. Const. 6; see also Drijvers, Cyril, 155. 


\section{Section 3: The Bordeaux Pilgrim}

The Bordeaux pilgrim's itinerary predates much of Eusebius's later writings on Palaestina, including both the Life of Constantine and his speeches on the Holy Sepulchre, as well as Cyril's lectures. Elsner discusses how the itinerary is also only twenty-six pages, 672 lines, in the original manuscript, with only about eight pages, 123 lines, dealing with the pilgrim's travels through Palaestina and Jerusalem. ${ }^{261}$ As Douglass argues, no known later traveler ever references this itinerary in their travels, and half of the later manuscripts remove the non-Palestinian sections completely. ${ }^{262}$

The very opening lines of the Bordeaux Itinerary provide historians with a view of the pilgrim's opinion of both Palaestina and the city of Jerusalem. The pilgrim opens the itinerary with the statement "An itinerary from Bordeaux to Jerusalem (Itinerarium a Burdigala Hierusalem usque)." ${ }^{263}$ This simple statement shows that the Bordeaux pilgrim was clear on the destination of the journey. Jerusalem was the endpoint of the journey, taking privilege over the rest of Palaestina. While the pilgrim would end up visiting many other locations on the way, Jerusalem was the end goal of this voyage.

While the first twelve pages of the itinerary do not explicitly address the pilgrim's views on Palaestina and Jerusalem, this section does set the groundwork for the rest of

\footnotetext{
${ }^{261}$ Elsner, "The Itinerarium Burdigalense," 183.

262 Douglas, "A New Look at the Itinerarium Burdigalense," 316-17. Douglass discusses the four surviving Itinerarium Burdigalense manuscripts. The Paris codex is the longest manuscript and therefore considered the most complete manuscript. The Verona codex is missing sections 604.1-611.7, a portion of the return trip from Judaea. The St. Gallen comprises only the Judaean portion, dropping both travel sections to Judaea and back. The Madrid codex is approximately the same as St. Gallen, but is much revised in the Holy Land sections 586.1-599.9. The differences between the travel sections in Paris and Verona codices are minimal and consisting mainly of scribal error and alterations in the spelling of place names. The fact that there were four different manuscripts show that the Itinerarium Burdigalense was shared but the removal of the travel section in half the manuscripts hints that it might not have been used as a travel guide. It seems likely that people were interested in the Itinerary primarily for the Palestine section.

${ }^{263}$ It. Burg. 549.1.
} 
the text and can lead to some interesting insights. For example, there are some striking similarities between the itinerary and other cartographic sources from antiquity, most noticeable the Antonine Itinerary, the Peutinger Map, and the Onomasticon. Not only do the Bordeaux and the Antonine Itineraries share a similar format, there is also a surprising overlap in the journey itself, especially between Milan and Palaestina. Some historians have even argued that the Bordeaux pilgrim might have had access to either a copy of the Antonine Itinerary or some of the other itineraries that helped form the Antonine Itinerary. ${ }^{264}$ There is also historical debate over the similarities between the Antonine Itinerary and the Peutinger Map, ${ }^{265}$ which has caused historians to debate any influences the Peutinger Map might have had on the construction of the Bordeaux Itinerary. ${ }^{266}$ Most significant for this thesis, however, is the similarities between the Bordeaux Itinerary and Eusebius's Onomasticon.

In an earlier section, I argued that it is very likely that Eusebius did not intend the Onomasticon to ever function as a pilgrimage guide. The fact that it is listed in alphabetical order alone would make it difficult for anyone to find it practical as a pilgrimage guidebook. It seems much more likely that it was intended as a scholarly aid for anyone studying the geography of the Bible. However, there are many similarities between the Onomasticon and the Bordeaux Itinerary. Both works use the Bible as a

\footnotetext{
${ }^{264}$ Douglas, "A New Look at the Itinerarium Burdigalense," 318-21; Elsner, "Piety and Passion,” 186-87. The similarities between the Bordeaux Itinerary and the Antonine Itinerary illustrate that limited number of major thoroughfares for travel in the ancient world.

${ }^{265}$ Benet Salway, "The Nature and Genesis of the Peutinger Map," Imago Mundi 57.2 (2005): 120.

${ }^{266}$ Douglas, "A New Look at the Itinerarium Burdigalense," 318-21; Elsner, "Piety and Passion," 186-87.
} 
source for mapping Palaestina, both cover many of the same cities and locations, and both most likely used pre-existing Roman itineraries as aids in their construction. ${ }^{267}$ Elsner argues that the Bordeaux pilgrim intentionally structured the itinerary to use the tropes of the Roman itinerary genre to transform them into a Christian narrative of holy spaces, and in so doing created a new genre of Christian sacred journey. ${ }^{268}$ According to this view, maps and itineraries, much like the Antonine Itinerary and Peutinger Map, were inherently propaganda to demonstrate imperial power, knowledge, and domination. ${ }^{269}$ The Bordeaux pilgrim would then have taken this propaganda and adapted the structure, but through the emphasis of Christian sites and history in preference to imperial centers of power, the pilgrim made Christianity the focus of the propaganda, not imperial Rome. This new vision of the empire included new principle metropolises, with cities like Jerusalem and Constantinople taking central positions with previous centers like Milan and Rome. ${ }^{270}$ Elsner's analysis of the structure and format of the Bordeaux Itinerary makes some very strong points, but I am unconvinced that this was an intentional move to create a new form of Christian sacred travel narrative. While this work reveals that, at least in the mind of the pilgrim, new cities were taking central

\footnotetext{
${ }^{267}$ Wolf, "Eusebius of Caesarea," 82; Irshai, "The Christian Appropriation of Jerusalem," 471. There is no concrete information that the pilgrim either was familiar with the Onomasticon or not, but it seems far more likely that the pilgrim made the journey without having read Eusebius's work.

268 Elsner, "Piety and Passion," 181.

269 Talbert, "Author, Audience and the Roman Empire," 256-70.

${ }^{270}$ Elsner, "Piety and Passion," 189. To make this argument, Elsner references the Bordeaux Itinerary's "grand summaries" of the journey at cities of great importance. For example, at It. Burg. 571.3-5 the pilgrim provides a summary of the "grand total" (omnis summa) of the entire journey from Bordeaux to Constantinople. At It. Burg. 601.1-3 the pilgrim makes another grand summary from Constantinople to Jerusalem. As Elsner argues, "What the structure of the IB's discourse presents is nothing less than a new vision of Empire with its principal urban metropoleis (at least as imagined by the text, whatever the actualities on the ground in 333) now Constantine's new capital - the new Rome - and the city of Jesus' Passion, in addition to the established Western capitals of Rome and Milan."
} 
positions in the mental map of the Empire, the Itinerary was structured as a personal account, not an attempt to create a new genre of travel narrative. The pilgrim was recording his or her personal experiences for posterity, and these experiences have helped historians better understand what some Christians could have thought of the Constantinian reforms of the fourth century. ${ }^{271}$ So the personal nature of the Itinerary, and the fact that no known traveler ever references the Bordeaux Itinerary, makes it unlikely this was ever intended as Christian propaganda. ${ }^{272}$

Once the Bordeaux pilgrim entered Palaestina, or Judaea as the itinerary refers to it, ${ }^{273}$ the tone of the work shifts radically. Instead of a simple travel log, the itinerary changes focus to become much more descriptive and keen to map territory onto scriptural events. In this section, the pilgrim provides a colorful, touristic, and pilgrim-centered account of the important biblical events throughout Palaestina and the Holy Land. ${ }^{274}$ The itinerary no longer simply lists the stops and distances, but instead becomes much more of a pilgrimage narrative. The first stop in Palaestina is at Caesarea. Immediately the pilgrim mentions how at this site a Roman centurion named Cornelius was converted to Christianity and baptized, referencing the account from Acts 10:1-48. ${ }^{275}$ Within the first few lines of crossing the border into Palaestina, the pilgrim begins to incorporate biblical history into the core of the travel narrative. The account of Palaestina begins with the

\footnotetext{
${ }^{271}$ For more information on how historians have used the Bordeaux Itinerary to understand fourth century Christianity see: Bowman, "Mapping History's Redemption"; Douglas, "A New Look at the Itinerarium Burdigalense"; Elsner, "The Itinerarium Burdigalense"; Irshai, "The Christian Appropriation of Jerusalem"; Leyerle, "Landscape as Cartography"; Smith, "My Lord's Native Land."

${ }^{272}$ Douglas, "A New Look at the Itinerarium Burdigalense," 316-17.

${ }^{273}$ It. Burg. 585.4.

${ }^{274}$ Elsner, "The Itinerarium Burdigalense," 183-85.

${ }^{275}$ It. Burg. 585.7-8.
} 
second Gentile to be recorded in the Bible to convert to Christianity. From this point on until the pilgrim begins the return journey home from Jerusalem, there are only two stops where the pilgrim does not make at least one reference to biblical history or some contemporary Christian tradition that the people practiced. ${ }^{276}$ It seems clear from the pilgrim's choice in the structure of the Palaestina section of the itinerary, Jerusalem had become a Christian city and that Palaestina shared its Old Testament history with New Testament history.

The Bordeaux Itinerary makes it clear that the pilgrim viewed the countryside of Palaestina outside of Jerusalem as very different space from the city itself. The most dramatic difference between the Palaestina section and the Jerusalem section is in the type of biblical references the pilgrim makes while walking through the broader region as compared to the biblical references made while in and around the city of Jerusalem. Between Caesarea and Jerusalem, the pilgrim makes twelve references to biblical history and one note about a contemporary spot of healing. Of these twelve biblical references, only two come from the New Testament Christian tradition. The pilgrim references the conversion of Cornelius the centurion at Caesarea and the meeting between Jesus and the Samaritan woman at the well in a place named Sichar. ${ }^{277}$ In comparison to these two events, the pilgrim makes note of ten separate sites of Jewish (Old Testament) history throughout the journey to Jerusalem. These sites include the place where David killed Goliath, the tomb of Joseph, the place where Jacob wrestled with the angel, and the site

\footnotetext{
${ }^{276}$ At Maximianoolis, It. Burg. 586.3, and at Scythopolis, It. Burg. 586.7.

${ }^{277}$ For the conversion of Cornelius, see It. Burg. 585.7-8. For Jesus and the Samaritan woman, see It. Burg. 588.2-5.
} 
of king Jeroboam's conversion, just to name a few. ${ }^{278}$ So, the vast majority of the recorded biblical traditions in the countryside of Palaestina were Jewish.

This emphasis on the Old Testament contrasts with the pilgrim's account of the city of Jerusalem, where he drastically shifts the biblical references towards a New Testament, Christian focus in the city. Upon entering the city, the pilgrim draws a connection between the Jewish history and Christian present of Jerusalem by immediately referencing four stories that link the Jewish king of Jerusalem, Solomon, with Jesus Christ. The first comment the pilgrim makes upon entering Jerusalem is to point out "two large pools...erected by Solomon." 279 The pilgrim does not even finish the sentence without drawing a direct connection between these two pools and two other pools directly involved with one of Jesus's most famous miracles, the healing of the paralytic at Bethesda. He completes the thought with "further in the city are twin pools... which are called Bethesda." ${ }^{280}$ The pilgrim then continues this connection between Solomon and Jesus with a second comparison. After discussing the two sets of pools, the pilgrim makes note of "a crypt, in which Solomon used to torture devils."281 Following this statement the pilgrim again tells a story from Jesus's life. The pilgrim recounts how Jesus was tempted by the devil on top of the temple and cast the devil away. ${ }^{282}$

These four stories, just seven lines from the pilgrim's narrative, are neatly organized and created an intentional and unavoidable comparison between Solomon, king

\footnotetext{
${ }^{278}$ It. Burg. 586.6 the site where David killed Goliath; It. Burg. 587.5-588.1 the tomb of Joseph; It. Burg. 588.10 the place where Jacob wrestled the; It. Burg. 588.10-589.3 the conversion of King Jeroboam.

${ }^{279}$ It. Burg. 589.7-8.

${ }^{280}$ It. Burg. 589.8-9; John 5:2-18; see also Irshai, "The Christian Appropriation of Jerusalem," 486.

${ }^{281}$ It. Burg. 589.11; Irshai, "The Christian Appropriation of Jerusalem," 486.

${ }^{282}$ It. Burg. 589.11-590.2; Compare to Matt 4:1-11.
} 
of the Jews, and Jesus Christ, the eternal king, son of God. In the first comparison, the pilgrim shows that Solomon the earthly king constructed pools for the earthly needs of his people, but Jesus, the heavenly king, provided divine healing and miracles through similar pools. In the second example, the pilgrim demonstrates Solomon's power and authority over demons through his ability to capture and torture them. However, the pilgrim then juxtaposes this account of Solomon with an even greater account of Jesus, who not only had power over demons, but demonstrated power over the devil himself to resist his temptations and send him away. There is also a vertical symmetry created in these two stories. Solomon had a crypt in the ground where he dealt with demons, Jesus went onto the very top of the temple to face the devil. Here the pilgrim is showing how much greater Jesus is to Solomon, contrasting the metaphorical underworld with the metaphorical heavenly realm of Solomon and Jesus respectively. ${ }^{283}$

As Irshai argues, the pilgrim here is helping the reader draw comparisons between two figures in Judeo-Christian history. Solomon king of the Jews and Jesus Christ the eternal king. ${ }^{284}$ In both accounts Solomon is rendered second to Jesus. In this way, the pilgrim used the history of Jerusalem to supplant Judaism with Christianity as the spiritual center of the city. The Jewish traditions were not being forgotten or suppressed, they were being reincorporated into Christian traditions and built upon to transform Jerusalem into the Christian Holy Land. Jerusalem was established in the mental map of the Bordeaux pilgrim as the eternal spiritual center built upon the foundations of the Jewish past. The impression the reader of the itinerary gets from this section is that the

\footnotetext{
${ }^{283}$ It. Burg. 589.7-590.2; see also Irshai, “The Christian Appropriation of Jerusalem,” 477-79.

${ }^{284}$ Irshai, "The Christian Appropriation of Jerusalem," 486.
} 
Christians came to possess Jerusalem, its history and traditions, and re-founded and elevated it as the new Christian Jerusalem. ${ }^{285}$

Smith argues that the Jewish understanding of sacred space was divided into thematic hierarchies. These hierarchies included the dichotomy between the sacred and profane, and the pure and impure. The Old Testament prophet, Ezekiel, provided a mental map of Jerusalem as a mountain with the top of the mountain being the sacred and at the bottom of the mountain was the profane. ${ }^{286}$ According to this mental map, the Jewish people understood a vertical hierarchy of space. At the summit of the metaphorical mountain was the Holy of Holies, God's throne, the temple rested below the Holy of Holies in significance, then comes the temple mount, and finally, at the bottom of the hierarchy is the land around the temple. The Bordeaux pilgrim, then, was taking this verticality of sacred space from its Jewish origins and turning it on its head to place the Jewish history and sacred space at the bottom of the hierarchy and therefore elevating Christianity to rest on top of sacred landscape of Jerusalem. ${ }^{287}$

The pilgrim next climbed Mount Sion to visit the Holy Sepulchre which was then under development. The journey up the mountain is presented as a brief passion narrative of the death of Jesus. First the pilgrim mentions the house of Caiaphas, where Christ was beaten the night of his death. ${ }^{288}$ After visiting Caiaphas's house, the pilgrim then directs the reader to where they could go to see the house of Pontius Pilate. He reminds us that

\footnotetext{
285 Irshai, "The Christian Appropriation of Jerusalem," 486.

${ }^{286}$ Ezk. 40.1-44.3; Smith, "To Take Place," 56-8.

287 Smith, "To Take Place," 56-8.

${ }^{288}$ It. Burg. 592.3-5; compare to Matt 26:57-68, where Jesus is tried and beaten at Caiaphas, the high priest's, house.
} 
"Here our Lord was tried before his passion." 289 The narrative continues when the pilgrim mentioned visiting both the hill of Golgotha, where Jesus was executed, and the tomb where Jesus rose from the dead. ${ }^{290}$ Finishing this account of the death and resurrection of Jesus, the pilgrim finally arrived at the Holy Sepulchre basilica that was ordered by Constantine. ${ }^{291}$

Throughout the pilgrim's journey through the city of Jerusalem he makes fourteen biblical references. Of these fourteen accounts, ten are drawn from the New Testament, and four are drawn from the Old Testament. The pilgrim references several accounts from Jesus life as well as an account of how Jesus is the cornerstone the Jews rejected, an account of the blood of Zacharias that remains in the temple to the pilgrim's day, as well as the remains of the marks in the temple of the nails in the shoes of the soldiers who killed Jesus. ${ }^{292}$ Each of these stories demonstrates the state of Jerusalem as a Christian city. Even the Jewish accounts provided by the pilgrim also develop the Christian authority of Jerusalem, where they draw a direct connection between Solomon and Jesus. ${ }^{293}$ The itinerary even mentions the remains of the Jewish temple that was destroyed during Hadrian's conquest of the city. Statues of Hadrian overlook the destroyed Jewish temple, and Jews are only allowed within the city once a year to mourn the destruction of the temple. ${ }^{294}$ The pilgrim makes it clear that the destruction of the Jewish temple was

\footnotetext{
${ }^{289}$ It. Burg. 593.1-3.

${ }^{290}$ It. Burg. 593.4-594.2.

${ }^{291}$ It. Burg. 5904.2-4.

${ }^{292}$ It. Burg. 590.3-4, the rejected cornerstone; It. Burg. 590.7-591.2, the blood of Zacharias; It. Burg. 591.23 , the marks of the nails in the ground.

${ }^{293}$ It. Burg. 589.7-8; 589.11; 590.4-6; see also Irshai, “The Christian Appropriation of Jerusalem,” 477-79.

${ }^{294}$ It. Burg. 591.4-6.
} 
prophesied by the prophets. ${ }^{295}$ In this way, every line of the Jerusalem section shows how, at least to the pilgrim, the city of Jerusalem had firmly become a Christian city.

After walking through Jerusalem, the pilgrim leaves the city to explore the country a bit more. On this stretch of the journey, he makes four major stops. The first area he visited outside of Jerusalem was the Mount of Olives. He climbed the Mount of Olives to see the second of Constantine's basilicas. ${ }^{296}$ After visiting the basilica and discussing the history of the site, the pilgrim then traveled to Jericho and witnessed the biblical history of the region. ${ }^{297}$ After Jericho, he then moved towards Bethlehem, the site of Jesus's birth and the third of Constantine's basilicas. ${ }^{298}$ Finally, before beginning the return journey home, he stopped at Mamre, to visit the fourth Constantinian basilica. ${ }^{299}$

In this last stretch of the journey, throughout the countryside around Jerusalem, the pilgrim makes nineteen biblical references. Ten of these references come from the New Testament, and the remaining nine come from the Old Testament. The passages referenced from the New Testament mostly deal with the multiple basilicas that Constantine was constructing. These events include the stone where Judas Iscariot killed himself, the palm tree whose branches were used for Jesus's entry into Jerusalem on Palm Sunday, the teachings of Jesus on the Mount of Olives, the transfiguration, the tomb of Lazarus, the place where Jesus was baptized, the site of Jesus's birth, and the spot where Philip baptized the eunuch. ${ }^{300}$ The Old Testament passages referenced in this

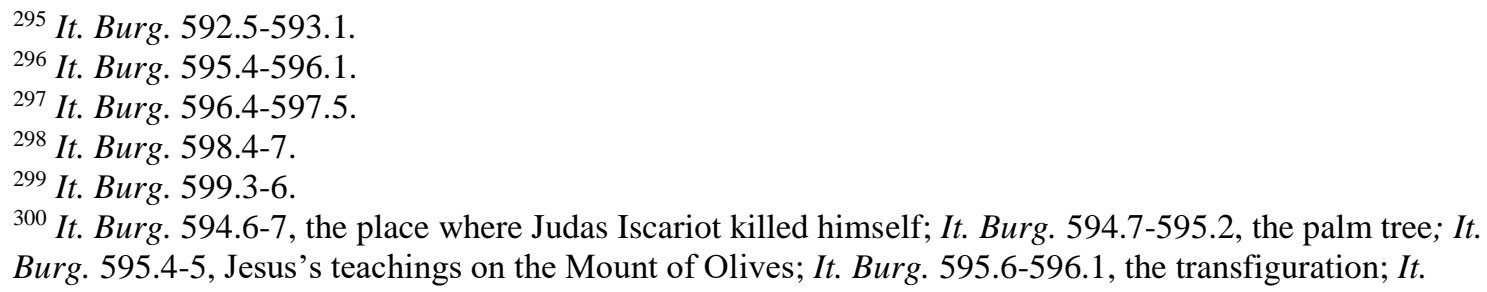


section of the itinerary mostly deal with events of great significance to Jewish and Christian history. These passages include the tomb of Isaiah and Hezekiah, a well that Elisha restored to help a woman, the place where the walls of Jericho fell, the place where Joshua circumcised the sons of Israel, the place where Elijah was called into heaven, and multiple tombs significant to Jewish people ${ }^{301}$ Several of these passages reference events and people that had a strong connection with Jesus. Isaiah provided many of the prophecies that foretold of Jesus's birth and life. The pilgrim mentions the tombs of Jesse, David, and Solomon, each of whom is mentioned in Matthew 1 as part of the genealogy of Jesus, through his father Joseph. Even the pilgrim's reference of Elijah's ascension into heaven mirrors the story of Jesus's ultimate ascension into heaven. While these events are Jewish in origin, multiple people and events that the pilgrim mentions draw connections between the Jewish history of Palaestina and the Christian present. ${ }^{302}$

The focus on Jewish history throughout the countryside could be explained by the fact that there was much more Jewish history to draw from while walking through Palaestina; the city of Jerusalem also had a rich Jewish history, but the pilgrim focused much more on the Christian history of the city. What seems evident is that in the mind of the pilgrim there is a clear divide between the Jewish, Old Testament history of the countryside and the Christian, New Testament history of Jerusalem. As Irshai argues, this shows a clear and intentional transformation of Jerusalem, one where the Jewish history

Burg. 596.2-3, tomb of Lazarus; It. Burg. 598.1-2, the place where Jesus was baptized; It. Burg. 598.5-6, the site of Jesus's birth; It. Burg. 599.1-2, Philip baptized the eunuch.

${ }^{301}$ It. Burg. 595.2-4 tombs of Isaiah and Hezekiah; It. Burg. 596.6-10; It. Burg. 597.2-5 the walls of Jericho fell; It. Burg. 597.5-6 Joshua circumcised the sons of Israel; It. Burg. 598.3 Elijah carried into heaven; It. Burg. 598.7-9 tombs of many important Jewish people.

${ }^{302}$ For Jesus' genealogy from Jesse, David, and Solomon, see Matthew 1:1-17; the story of Elijah's ascension into heaven, 2 Kings 2:1-11; compare the story of Jesus's ascension into heaven, Acts 1:9-11. 
is incorporated into a framework of Christian history, taking it away from the Jews and placing it firmly in the Christian realm. ${ }^{303}$

The way the pilgrim views the countryside of Palaestina and the city of Jerusalem can be illuminated through an analysis of his description of the journey through the land. When entering Palaestina through Caesarea the majority of the biblical stories and history mentioned were Jewish in nature. Upon entering the city of Jerusalem there was a dramatic shift in the pilgrim's focus in the itinerary. The stories and events mentioned in the itinerary focus more on Christian events. While the pilgrim did mention the Jewish history of the city, each reference to this Jewish history was designed to build up the contemporary Christian nature of Jerusalem. Christianity had emerged from Judaism and absorbed much of its culture and history. This is evident in the pilgrim's account of Jerusalem and the comparisons made in the text between Solomon and Jesus. ${ }^{304}$ When the pilgrim finally left Jerusalem to explore the countryside surrounding the city, the biblical references are split fairly evenly, with ten Christian references and nine Jewish references. Here the pilgrim went to sites of great significance to the life of Jesus where Constantine was building his many basilicas, yet the pilgrim also chooses to visit sites of great importance to the Jewish elements of Christian history, including the tombs of Isaiah, David, and Solomon.

The pilgrim is also careful to bookend the journey through Palaestina with two important stories of Gentile conversions to Christianity. The first element of Palaestina

\footnotetext{
${ }^{303}$ Irshai, "The Christian Appropriation of Jerusalem," 473-74.

${ }^{304}$ Irshai, "The Christian Appropriation of Jerusalem," 473-74.
} 
explored by the pilgrim is the conversion of Cornelius at Caesarea. ${ }^{305}$ One of the last references the pilgrim makes before the return journey home is the baptism of the eunuch by Philip. ${ }^{306}$ These two stories are the first two conversions of Gentiles in the Bible. ${ }^{307}$ By starting and ending the Palaestina section with these two accounts the pilgrim makes it clear that this land has become Christian in nature. In structuring the itinerary this way, the pilgrim reveals his or her perceived importance of the Jewish history of Palaestina, but also how this has successfully been incorporated into the Christian tradition, making Palaestina, and Jerusalem in particular, the Christian Holy Land.

Most of the travel narrative from Bordeaux to Palaestina makes no mention of any wonders or miracles. ${ }^{308}$ Yet when the pilgrim reaches Palaestina the account begins to fill up with sites of healings and supernatural occurrences. The second point of interest the pilgrim makes upon reaching Palaestina, after the account of the conversion of Cornelius, is a fountain where women wash and become pregnant. ${ }^{309}$ Upon reaching Jerusalem, the pilgrim mentions pools where Jesus healed the paralytic, and includes a note that says people are still healed at the site to this day. ${ }^{310}$ At Mount Sion, the pilgrim mentions a spring that stops running on each sabbath. ${ }^{311}$ The pilgrim even mentions how at the Dead Sea any man who enters the sea will be turned over by the water, which would have

\footnotetext{
305 It. Burg. 585.7-8: Ibi est balneus Cornelii centurionis, qui multas elymosynas faciebat.

${ }^{306}$ It. Burg. 599.1-2: Inde Bethasora mila XIIII, ubi est fons, in quo Philippus eunuchum baptizavit.

307 The first Gentile conversion to Christianity in the Bible is an unnamed Ethiopian eunuch who was baptized by Philip, Acts 8:26-40. The second Gentile to be converted to Christianity was the Roman centurion, Cornelius, who Peter testified to and baptized in Acts 10:1-48.

308 There are a few points where the travel section of the itinerary does reference biblical events or miracles, but these are rare. The pilgrim mentions the birthplace of Paul, It. Burg. 579.4, Sarepta, where Elijah begged a woman for food, It. Burg. 583.13 (1 Kings 17:1-16), Mount Carmel where Elijah offered a miraculous sacrifice, It. Burg. 585.1 (1 Kings 18:19-40).

${ }^{309}$ It. Burg. 585.9-586.2.

${ }^{310}$ It. Burg. 589.9-11.

${ }^{311}$ It. Burg. 592.2-3.
} 
seemed miraculous to the pilgrim. ${ }^{312}$ Palaestina was not a land like the rest of the Roman Empire; the itinerary does not mention any such wondrous healings and miracles outside of Palaestina. Eusebius, as we have seen, believed that Palaestina held no spiritual or miraculous powers; the land was historically holy and nothing more. The Bordeaux pilgrim, however, reflects what Cyril argued. Palaestina, and particularly Jerusalem, were not just historically significant, but they were in a real and physical sense, holy, powerful, and able to affect the lives of Christians on a personal level. ${ }^{313}$

There is one last point to mention about how the Bordeaux pilgrim understood the land of Palaestina. He was very selective in what was included and excluded from the itinerary. Unlike many other geographical surveys of a specific region provided in antiquity, throughout the entire itinerary, the pilgrim took no special interest in the nature of the terrain, the flora or fauna of the region, or even the people. ${ }^{314}$ For the pilgrim, the

\footnotetext{
${ }^{312}$ It. Burg. 597.7-10.

${ }^{313}$ Elsner, "The Itinerarium Burdigalense," 192.

${ }^{314}$ Rivkah Fishman-Duker, ""Jerusalem: Capital of the Jews": The Jewish Identity of Jerusalem in Greek and Roman Sources," Jewish Political Studies Review 20.3/4 (2008): 132. Fishman-Duker argues that "For ancient Greek and Roman pagan writers, Jerusalem was a Jewish city, and the site of the Temple, the holy place of the Jews. It was founded in the remote past by ancient Jews, possibly by Moses, who led a pariah people, expelled from Egypt, and established its theology, laws and customs, which were and continued to be inimical to most of humanity." In 43, Pomponius Mela wrote his Chorographia. Book 1.62-64 of this work describes the region of Syria, which is known by different names in different places, including Palestine and Judaea. He describes the rivers, cities, peoples, and legends of the region, but makes no reference to the city of Jerusalem. Pliny the Elder, in 79, before Hadrian's destruction of the city, discussed Judaea in his Naturalis Historia 5.66-73. In 5.70 Pliny briefly discussed Jerusalem saying that Judaea was "the district that formerly contained Jerusalem, by far the most famous city in the east and not of Judaea only." (in qua fuere Hierosolyma longe clarissima urbium orientis, non ludaeae modo). In 110, Tacitus included a brief account of the Jews in his Histories. Tacitus spends most of his account chronicling the destruction of Jerusalem under Titus, since his work spends a great deal of attention on the Flavian dynasty, the theme of his work. Tacitus describes the history of the Jewish people, their exile from Egypt, the connections between their religion and the Roman religion, and the geography of Judaea. Tacitus describes the local flora, weather patterns, rivers, dead sea, and towns and villages. When discussing Jerusalem, Tacitus called it "the capital of the Jews" and moved on to discuss the fortifications of the city and temple. Tact. Hist. 5.1-12. In general, the Roman sources discuss the geography of Judaea in much more detail concerning the land and people, compared to the Bordeaux pilgrim who discussed the religious significance of the history of the land, over its geography.
} 
reason for the journey and the major interest in the written account are the sites themselves. While the pilgrim mentioned features of the geographical terrain, like rivers, pools, and mountains, these are only mentioned because of the cultural constructions built upon the physical geography. ${ }^{315}$ The pilgrim walked up Mount Sion and the Mount of Olives not because they are important elements of the geography, but because they are the sites where Constantine built his basilicas. On the journey to Jerusalem from Caesarea, the pilgrim skipped both Nazareth and the Sea of Galilee, both of which were locations of great significance to biblical, New Testament history. These two sites were not out of the pilgrim's way; it would not have been difficult to include them on the journey. However, as Leyerle argues, these sites were not developed, there were no great landmarks or churches at Nazareth or the Sea of Galilee at the time to go and experience. The pilgrim did not take the most direct route to Jerusalem. He went out of the way to visit places that would have held some significance for a pilgrim. The locations that were most developed in the itinerary are the ones where there was the most to see and experience, including Solomon's palace, the Constantinian basilicas, and Jericho. The Bordeaux pilgrim, it appears, aimed to experience the most exciting archaeological tour. This journey, according to Leyerle, was a "greatest hits" of the biblical sites, churches, and healing shrines of Palaestina. The pilgrim was not simply trying to experience the

\footnotetext{
${ }^{315}$ For example, in It. Burg. 588.5-6 the pilgrim references some trees, but explicitly mentions that these trees were planted by Jacob, in It. Burg. 588.9 the pilgrim references an almond tree that that Jacob slept under and was given a vision by God, in It. Burg. 592.2-3 the pilgrim references a spring that does not run on the sabbath, in It. Burg. 594.2-4 the pilgrim ascends Mount Sion, but is explicit that this area is important because of the Holy Sepulchre, similarly, in It. Burg. 595.5-596.1 the pilgrim makes it clear that the Mount of Olives is important for the Eleona church that Constantine is building. In It. Burg. the pilgrim references that Sycamore tree that Zacchaeus climbed to see Jesus.
} 
biblical history of the land, but instead focused on the experience of seeing and touring the many wondrous sites that Palaestina had to offer. ${ }^{316}$

\section{Conclusion}

Eusebius, Cyril, and the Bordeaux pilgrim each understood Palaestina in a different manner. Both Eusebius and Cyril approached the issue as bishops of the Church with the power and resources available to them in their positions. The pilgrim, on the other hand, walked through Palaestina as a stranger, visiting the Holy Land for only a limited time. Eusebius and Cyril were both natives to Palaestina, while the pilgrim was a visitor from a distant land. Eusebius and the pilgrim each experienced Palaestina and Jerusalem while Constantine was still alive and starting his building programs, whereas Cyril became bishop and composed his lectures after the emperor's death. Eusebius wrote his books as a scholar, interested in a deep intellectual and theological study of the issues he addressed. Cyril spoke as an orator directly to his audience and might have never intended his lectures to be written down. Cyril's audience was mostly composed of pilgrims who might have been unfamiliar with the area and new Christians. He spoke to his audience's senses, rather than their intellect. While the pilgrim never heard one of Cyril's lectures, they would most likely have appealed to the pilgrim much more than Eusebius writings would have. Each of these three sources understood and agreed that Palaestina and Jerusalem were historically very significant, yet only Cyril and the pilgrim believed the land was in a real and miraculous sense, holy.

${ }^{316}$ Leyerle, "Landscape as Cartography," 123-26. 
Eusebius believed that Palaestina was significant for its rich history, but the land itself held no spiritual or theological power in the present day. He believed in a Christianity that was not place bound. Every Christian was free to worship in spirit and in truth and where a Christian worshiped made no difference to their spiritual position. Jerusalem had been judged by God through the Emperor Hadrian and now was no more important than any other city in the world. Eusebius focused on a spiritual Jesus in his writings, one that was not tied to any physical spot, but could be accessed through prayer and study of the Bible anywhere. While he would come to call the tomb of Christ's resurrection holy, he did not reverse his views on the significance of Jerusalem.

Cyril took a very different approach. He believed that the land connected to Christ held power, which gave it the ability to witness and testify to the truth of the gospel. $\mathrm{He}$ believed that the sites that witnessed Christ in his life can themselves serve as witnesses to Christ to proclaim the truth of the Gospels. For a Christian in Palaestina, being near the places where Jesus walked and preached offered spiritual closeness to God that could not be reached anywhere else. Cyril worked to turn opinions back from the spiritualized Christianity that Eusebius promoted. Instead he argued for a real, physical view of Christ, who lived and died on Golgotha. He promoted a view of Jerusalem and Golgotha that put them at the focus of the mental map of all Christians, making them the center of the world in a tangible sense.

The pilgrim's views resemble Cyril's opinions of the holiness of the land. While the pilgrim spends most of the Palestinian section of the itinerary focused on the rich biblical history of the land, this is not the sole focus of the narrative. For the pilgrim, the land of Palaestina was full of wonder and power. He makes it clear that there is more to 
Palaestina than just the biblical history. The rich Jewish history referenced in the countryside around Jerusalem and the dramatic shift to Christian history and culture once the pilgrim arrives at the city shows that, in the mind of the pilgrim, Christianity had supplanted Judaism as the religion of Palaestina. The Jewish history of the region was not forgotten, nor downplayed, but instead fully incorporated into the contemporary Christian culture. Yet Palaestina was not only a land rich with history; it was also filled with miracles and healings to the present day. While the pilgrim might not have agreed fully with either Eusebius or Cyril on the significance of Palaestina, it seems clear that in the mind of the pilgrim there is much more to Palaestina than just its history and that it was a land worth crossing the Roman Empire to visit, even temporarily. 


\section{Chapter 5}

\section{Conclusion}

In 324/5, Constantine defeated his political rivals and became the first sole emperor of the Roman Empire since Diocletian in 285. ${ }^{317}$ After this victory, Constantine began to implement changes throughout the Empire. He moved the capital of the Empire from Rome to Constantinople in the east, he ended Christian persecution throughout the entire empire, he worked to unify the Christian church and rule out heresy under the council of Nicaea, and he began many building programs throughout the Empire.

Palaestina was one of the multiple regions that received Constantine's patronage. ${ }^{318}$ Yet this patronage would have lasting effects on the region. Constantine's Holy Land policy created a shift in the Christian understanding of the religious and historical significance of Palaestina and the city of Jerusalem in the fourth century that would shape the region for centuries.

Constantine's reforms in Palaestina affected many Christians throughout the region long after his death. One important point to consider about our three sources is the timeframe of their works. Cyril's Catechetical Lectures and the Bordeaux Itinerary provide only a brief historical snapshot of their creators. Cyril composed his lectures over no more than a few years, and he might have composed his lectures during his first year as bishop of Jerusalem. The Bordeaux Itinerary represents a single journey of the nameless pilgrim to Jerusalem. There is most likely much more to the lives of these two

\footnotetext{
317 Potter, Constantine, 207-13.

318 Armstrong, "Constantine's Churches," 13-16; Drijvers, Cyril, 11-13; Potter, Constantine, 37-38, 51, 239-47; Tsafrir, Ancient Churches Revealed, 1-5; Tsafrir, "Byzantine Jerusalem," 133-39; Walker, Holy City, 15-22.
} 
people that historians will never know. Eusebius, however, wrote many works over the course of his long life. Much of this thesis' analysis of Eusebius has had to take a nuanced view of his opinions because Eusebius, like any person, changed throughout his life. As he experienced different circumstances, he changed, and so did his writings. These changes complicate the historical scene but provide us with a more developed view of Eusebius.

Eusebius and Cyril both interpreted Constantine's development of Palaestina in radically different ways. For Eusebius, Palaestina was historically a land of great significance. This was the land where most of biblical history occurred. In Palaestina Jesus was born, lived his life, died, and rose from the grave. However, to Eusebius, this historical significance was not enough to give the land any theological significance. Palaestina rejected and killed Jesus, thus earning it God's judgment in the form of the Roman destruction of Jerusalem in 70 and 135. For these reasons, Eusebius argued that Palaestina in no way superseded the rest of the world. Even as the bishop of Caesarea, the political and religious center of Palaestina in the early fourth century, Eusebius pushed for a spiritualized understanding of Jesus, one completely separated from the land, who could be worshiped anywhere in the world in spirit and in truth. Eusebius effectively worked to move Constantine to an imperial view of Christianity, where any Christian could worship God equally. This imperial Christianity favored the imperial present over the biblical past and Caesarea over Jerusalem. Cyril of Jerusalem pushed for a different focus of Christian attentions. 
For Cyril, the land of Palaestina was central to Christianity. The ground where Jesus walked was holy. Palaestina was filled with sites where holy events occurred in history, and this proximity to such holy moments transferred some holiness to the land itself. Cyril filled his lectures with examples of locations that act as living witnesses to Christ and the biblical narrative. ${ }^{319}$ These sites were not dead relics, but living testimonies that provided Christians with real, and powerful accounts of the life of Jesus. Cyril said that being in Palaestina grants a Christian the ability to touch and see the blessings of Christ, while others can only hear about this power second hand. While it was possible to be a Christian anywhere, according to Cyril, it was only in Palaestina that a Christian had the full access of the blessings that God granted his people through the life of Christ. Palaestina was not just important for Cyril; Jerusalem and the rock of Golgotha, the site where Christ died, were so powerful that they had become the center of the world, a view that would last throughout the Middle Ages and shape an entire worldview for many Christians. Cyril rejected the idea of a spiritualized Jesus, separated from the land, and instead promoted a view that emphasized the physical Jesus and his death on Golgotha.

One point needs to be addressed about the structure of this thesis. While much of this thesis contrasts Eusebius and Cyril's views on Palaestina and the city of Jerusalem, they never personally debated with each other over any of these issues. Eusebius died over a decade before Cyril became bishop of Jerusalem and they never had an opportunity to directly argue the theological implications of Constantine's developments

${ }^{319}$ Catech. 10.19, 13.38-39, 14.22-23. 
of Palaestina. They were two voices in a much larger Christian debate. Eusebius and Cyril were chosen as sources for this thesis because they express opposing sides of this discussion, yet they both address similar points in their arguments. They were important voices who would shape the nature of Christian Palaestina in their time, and yet they illustrate that for Christians any consensus regarding the Holy Land was constantly being renegotiated.

Eusebius and Constantine both demonstrate a level of nuance in this story that can add difficulty to the historical narrative. Eusebius both wanted to separate Christianity from the land and make it so that all Christians everywhere were equally privileged. No land or physical object possesses any spiritual powers that would aid the Christian in his spiritual journey to God. At the same time, however, Eusebius pushed Constantine to continue his developments of the region of Palaestina to further his position as the Metropolitan bishop of the province, even when it meant Constantine poured resources into Jerusalem, the center of Eusebius's chief rivals. Eusebius never outright condemned Constantine for the building of the Churches or the creation of a Holy Land in Palaestina, but his theological views on the matter made it clear that he did not support this idea of a Holy Land. This issue cannot be resolved by saying that Eusebius simply changed his mind at some point throughout his life. It seems that perhaps Eusebius knew that his political position would benefit from Constantine's work, and he did not want to risk this, even though his theological beliefs differed. Or perhaps Eusebius, who lived through most of his life under imperial persecution, simply wanted to encourage the first emperor who had such a positive view of Christianity, whatever the cost. 
Constantine also presents historians with a level of nuance that complicates the story. Constantine wanted people focusing on Palaestina, but at the same time he was pushing for an imperial Christianity with him at the head, which distanced Christianity from the land. Maybe Constantine wanted to spread Christianity throughout the entire Empire, while at the same time keeping the focus of the religion centered in one region, perhaps even on one city. What could be a more dramatic view of imperial authority and strength as the head of the Christian faith than Christians from all corners of the empire worshiping Christ, but at the same time being able to journey to the land Constantine created as the Holy Land? Yet this thought brings up another question: if Constantine was reshaping the empire, moving the political capital to Constantinople and creating a new religious center for the empire, why did Constantine choose Palaestina as the center, and not some other region, or even the newly developed Constantinople? Although there is more work to be done, it may well be that Cyril's focus on the Holy Land, or rather those who shared Cyril's views but lived during the time of Constantine, was more powerful than we think.

One of the chief goals of this thesis was to introduce the Bordeaux pilgrim into the Christian debate in which Eusebius and Cyril were two voices. Much of the unique research of this thesis works to show how the pilgrim viewed Palaestina and Jerusalem as part of a developing Christian worldview to help illuminate what Constantine might have been trying to develop in his creation of the Christian Holy Land. The Bordeaux Itinerary recounts the travels of an unknown Christian pilgrim from Bordeaux in modern day southern France to Jerusalem, the center of much of Constantine's developments. The 
pilgrim shows that not only had Christianity spread throughout the Empire, like Constantine wanted, but Palaestina had become a site of great attraction for Christians. The pilgrimage was undertaken in 333, less than a decade after Constantine's work began in Palaestina. The pilgrim visited each of Constantine's four basilicas, even the Holy Sepulchre which would not have been finished until years after the pilgrim's visit. Yet, after the pilgrim visited the important sites, he returned home, leaving Jerusalem.

Like Cyril, the pilgrim believed the countryside of Palaestina had gained some holiness and power through its connection to Christ, mentioning multiple sites of healing and miracles throughout the journey. However, the pilgrim would have also likely agreed with Eusebius that the region had a great historical significance, but Christians were free to worship God anywhere. This was a visit to see and experience the sites of Palaestina, not a relocation to the Holy Land because any true Christian needed to live in Palaestina. It seems likely that this pilgrimage shows that an imperial view of Christianity was spreading. The pilgrim found Palaestina an interesting place to visit for a time and experience the sites as a tourist, but there is no sign that the pilgrim had any desire to move to Palaestina. Christians desired to live throughout the Empire as Christianity spread, but there was still interest in the historical and theological significance of Palaestina and Jerusalem.

The Bordeaux pilgrim also highlights some important aspects of Eusebius and Cyril's theological debates. His views fall much closer to those which Cyril would eventually present. The pilgrim thought that Palaestina and the city of Jerusalem were important, even relegating Caesarea to little more than a footnote in the journey towards 
Jerusalem. He made it clear throughout his travels through Palaestina that there was a rich history to the land, and that Christianity had supplanted the Jewish history of the land. Both Eusebius and Cyril supported Constantine's developments of Palaestina. Eusebius, however, did not want most of the attention falling solely on Jerusalem. The pilgrim seems to hold a similar mindset towards Jerusalem. In the itinerary, he also spent more time in Palaestina outside the walls of Jerusalem than inside the city. Even though the land had great significance, the pilgrim eventually decided to go home after this temporary visit. Cyril focused his lectures to an audience of new Christians and pilgrims and would have no doubt attracted the interests of the Bordeaux pilgrim more than Eusebius would have if they had ever met, but, unsurprisingly, the pilgrim did not have a worldview that aligned fully with either one of the two church fathers. Each of these three sources have a unique view of Palaestina and Jerusalem, and when added together illustrate the viewpoints that must have existed in various levels of society as Constantine tried to form a Christian Holy Land within the Roman Empire. 


\section{Bibliography}

\section{Primary Sources:}

Bordeaux Pilgrim, The. Itinerary from Bordeaux to Jerusalem. Translated by Aubrey Stewart. Palestine Pilgrim's Text Society. London: Committee of the Palestine Exploration Fund, 1887.

Cyril, Saint. The Works of Saint Cyril of Jerusalem. Translated by Leo P.

McCauley. Vol. 1-2. 2 vols. Fathers of the Church 61. Washington, D.C.:

Catholic University of America Press, 1969.

Eusebius of Caesarea. Ecclesiastical History: Complete and Unabridged. Translated by Christian Frederic Crusé and Hendrickson Publishers. New Updated ed. Peabody, Mass.: Hendrickson Publishers, 1998.

- Life of Constantine. Translated by Averil Cameron and Stuart George Hall. Clarendon Ancient History Series. Oxford: Oxford University Press, 1999.

—. The Onomasticon: Palestine in the Fourth Century A.D. Translated by G.S.P. Freeman-Grenville. Jerusalem: Carta, 2003.

- Preparation for the Gospel. Twin Brooks Series. Translated by Edwin Hamilton Gifford. Grand Rapids, MI: Baker Book House, 1981.

- The Proof of the Gospel. Twin Brooks Series. Translated by William John Ferrar. Grand Rapids, MI: Baker Book House, 1981.

Mela, Pomponius. Pomponius Mela's Description of the World. Translated by F. E. Romer. Ann Arbor: University of Michigan Press, 1998.

Tacitus. The Histories. Translated by W. H. Fyfe. Oxford; New York: Oxford University Press, 2008.

Talbert, J. A. Rome's World: The Peutinger Map Reconstructed. Cambridge: Cambridge University Press, 2010. 


\section{Secondary Sources:}

Adams, Colin E. P., Ray Laurence, and Roman Archaeology Conference. Travel and Geography in the Roman Empire. London: Routledge, 2001.

Albu, Emily. "Imperial Geography and the Medieval Peutinger Map." Imago Mundi 57.2 (2005): 136-48.

Armstrong, Gregory T. "Constantine's Churches: Symbol and Structure." Journal of the Society of Architectural Historians 33.1 (1974): 5-16.

Avigad, Nahman. Discovering Jerusalem. Nashville: TNelson, 1983.

Baynes, Norman Hepburn. Constantine the Great and the Christian Church. Raleigh Lecture on History; 1929. London: HMilford, 1930.

Bianchetti, Serena. Brill's Companion to Ancient Geography: The Inhabited World in Greek and Roman Tradition. Brill's Companions in Classical Studies. Leiden: Brill, 2015.

Bitton-Ashkelony, Brouria. Encountering the Sacred The Debate on Christian Pilgrimage in Late Antiquity. Transformation of the Classical Heritage. Berkeley: University of California Press, 2005.

—. "The Attitudes of Church Fathers Towards Pilgrimage to Jerusalem in the Fourth and Fifth Centuries." In Jerusalem: Its Sanctity and Centrality to Judaism, Christianity, and Islam, edited Lee I. Levine, 188-203. New York: Continuum, 1999.

Bowman, Glenn. "Mapping History's Redemption: Eschatology and Topography in the Itinerarium Burdigalense." In Jerusalem: Its Sanctity and Centrality to Judaism, Christianity, and Islam, edited Lee I. Levine, 163-187. New York: Continuum, 1999.

Crawford, O. G. S. "A Note on the Peutinger Table and the Fifth and Ninth Iters." The Journal of Roman Studies 14 (1924): 137-41.

Crowfoot, John Winter. Early Churches in Palestine. Schweich Lectures; 1937. College Park, Md.: McGrath PubCo, 1971.

Douglas, Laurie. “A New Look at the Itinerarium Burdigalense.” Journal of Early Christian Studies 4.3 (Fall 1996): 313-333. 
Doval, Alexis James. Cyril of Jerusalem, Mystagogue: The Authorship of the Mystagogic Catecheses. Patristic Monograph Series; 17. Washington, D.C.: Catholic University of America Press, 2001.

Drake, Harold Allen. In Praise of Constantine: A Historical Study and New Translation of Eusebius's Tricennial Orations. University of California Publications. Classical Studies; 15. Berkeley: University of California Press, 1976.

—. "The Return of the Holy Sepulchre." The Catholic Historical Review 70.2 (1984): 263-67.

Drijvers, Jan Willem. Cyril of Jerusalem: Bishop and City. Leiden: Brill, 2004.

Edson, Evelyn. "Maps in Context: Isidore, Orosius, and the Medieval Image of the World." In Cartography and World in Antiquity and the Middle Ages: Fresh Perspectives, New Methods, edited by R. Talbert and R. Unger, 219-236. Leiden: Brill, 2008.

—. "World Maps and Easter Tables: Medieval Maps in Context." Imago Mundi 48 (1996): 25-42.

Eliav, Yaron Z. God's Mountain: The Temple Mount in Time, Place, and Memory. Baltimore: Johns Hopkins University Press, 2005.

Elliott, T. G. "Constantine's Conversion: Do We Really Need It?" Phoenix 41.4 (1987): 420-38.

Elsner, Jas. "Pausanias: A Greek Pilgrim in the Roman World." Past \& Present, 135 (May 1992): 3-29.

-. "The Itinerarium Burdigalense: Politics and Salvation in the Geography of Constantine's Empire.” The Journal of Roman Studies 90 (2000): 181-195.

- "Piety and Passion: Contest and Consensus in the Audiences for Early Christian Pilgrimage." In Pilgrimage in Graeco-Roman \& Early Christian Antiquity, edited by Jas Elsner and Ian Rutherford, 411-434. Oxford: Oxford University Press, 2007.

-, and Ian Rutherford, edit. Pilgrimage in Graeco-Roman \& Early Christian Antiquity: Seeing the Gods. Oxford: Oxford University Press, 2007.

Fishman-Duker, Rivkah. "'Jerusalem: Capital of the Jews": The Jewish Identity of Jerusalem in Greek and Roman Sources." Jewish Political Studies Review 20.3/4 (2008): 119-40. 
Harland, Philip A., and Canadian Corporation for Studies in Religion. Travel and Religion in Antiquity. Studies in Christianity and Judaism; 21. Waterloo, Ont.: Wilfrid Laurier University Press, 2011.

Hollerich, Michael J. 'Myth and History in Eusebius's 'De Vita Constantini': 'Vit. Const. 1.12' in Its Contemporary Setting." The Harvard Theological Review 82.4 (1989): 421-45.

Holum, Kenneth G. "Hadrian and St. Helena: Imperial Travel and the Origins of Christian Holy Land Pilgrimage." In The Blessings of Pilgrimage, edited by Robert G. Ousterhout, 66-81. Illinois Byzantine Studies; 1. Urbana: University of Illinois Press, 1990.

Hunt, E. D. Holy Land Pilgrimage in the Later Roman Empire, AD 312-460. Oxford: Oxford University Press, 1982.

-. "Where there Christian Pilgrims before Constantine?" in Pilgrimage Explored, edited by J. Stopford, 25-40. University of York: York Medieval Press, 1999.

Irshai, Oded. "The Christian Appropriation of Jerusalem in the Fourth Century: The Case of the Bordeaux Pilgrim." The Jewish Quarterly Review, 90.4 (Fall 2009): 465-486.

Isaac, Graham R. The Antonine Itinerary Land Routes: Place-Names of Ancient Europe and Asia Minor. Aberystwyth: CMCS Publications, 2002.

Jacobs, Andrew S. Remains of the Jews: The Holy Land and Christian Empire in Late Antiquity. Divinations. Stanford: Stanford University Press, 2004.

Johnson, Aaron P. "Greek Ethnicity in Eusebius's 'Praeparatio Evangelica."” The American Journal of Philology 128.1 (2007): 95-118.

Jones, Tom B., and Hoyt, Robert S. In the Twilight of Antiquity: The R.S. Hoyt Memorial Lectures (1973). Minneapolis: University of Minnesota Press, 1978.

Kalleres, Dayna S. "Cultivating True Sight at the Center of the World: Cyril of Jerusalem and the Lenten Catechumenate 1." Church History 74.3 (2005): 431-59.

Kofsky, Arieh. Eusebius of Caesarea against Paganism. Jewish and Christian Perspectives Series; v.3. Leiden; Boston: Brill, 2000.

Krautheimer, Richard. "The Constantinian Basilica.” Dumbarton Oaks Papers 21 (1967): 115-40. 
Lenski, Noel. "Empresses in the Holy Land: The Creation of a Christian Utopia in Late Antique Palestine." In Travel, Communication, and Geography in Late Antiquity: Sacred and Profane edited by Linda Ellis and Frank Kidner, 113125. Burlington, VT: Ashgate, 2004.

Levine, Lee I. Jerusalem: Its Sanctity and Centrality to Judaism, Christianity, and Islam. New York: Continuum, 1999.

Leyerle, Blake. "Landscape as Cartography in early Christian Pilgrimage Narratives." Journal of the American Academy of Religion, 64.1 (Spring, 1996): 119-143.

Liddell, Henry George, and Robert Scott. Liddell and Scott's Greek-English Lexicon. Oxford: Simon Wallenburg Press, 2007.

MacMullen, Ramsay. Christianity and Paganism in the Fourth to Eighth Centuries. New Haven: Yale University Press, 1997.

Magness, Jodi. The Archaeology of the Holy Land: From the Destruction of Solomon's Temple to the Muslim Conquest. Reprinted with corrections 2013. Cambridge: Cambridge University Press, 2013.

Maraval, Pierre. "The Earliest Phase of Christian Pilgrimage in the Near East (before the 7th Century)." Dumbarton Oaks Papers 56 (2002): 63-74.

Millar, Fergus. The Emperor in the Roman World, 31 BC-AD 337. Ithaca: Cornell University Press, 1977.

Oldham, R. D. "The Antonine Itinerary of the Aurelian Road between Aix and Arles." The Geographical Journal 72.1 (1928): 58-60.

Ousterhout, Robert G. The Blessings of Pilgrimage. Illinois Byzantine Studies; 1. Urbana: University of Illinois Press, 1990.

Patrich, Joseph. "The Early Church of the Holy Sepulchre in the Light of Excavations and Restoration." In Ancient Churches Revealed, edited by Toram Tsafrir, 101117. Jerusalem: Israel Exploration Society, 1993.

Potter, David Stone. Constantine the Emperor. Oxford: Oxford University Press, 2013.

Price, Simon. "Religious Mobility in the Roman Empire." The Journal of Roman Studies 102 (2012): 1-19. 
Pullan, Wendy. "'Intermingled Until the End of Time': Ambiguity as a Central Condition of Early Christian Pilgrimage." In Pilgrimage in Graeco-Roman \& Early Christian Antiquity, edited by Jas Elsner and Ian Rutherford, 387-409. Oxford: Oxford University Press, 2007.

Rivers, Joseph. Pattern and Process in Early Christian Pilgrimage. PhD diss. Duke University, 1983

Rutherford, Ian C., Merkt, Andreas (Mainz) and Toral-Niehoff, Isabel (Freiburg), "Pilgrimage," in: Brill's New Pauly, Antiquity volumes edited by Hubert Cancik and, Helmuth Schneider.

Salway, Benet. "The Nature and Genesis of the Peutinger Map." Imago Mundi 57.2 (2005): 119-35.

Salzman, Michele Renee, editor, Marianne Sághy editor, and editor Rita Lizzi Testa. Pagans and Christians in Late Antique Rome: Conflict, Competition, and Coexistence in the Fourth Century. New York: Cambridge University Press, 2016.

Schiffman, Lawrence H. "Jerusalem: Twice Destroyed, Twice Rebuilt." The Classical World 97.1 (2003): 31-40.

Schwartz, Seth. Imperialism and Jewish Society, 200 B.C.E. to 640 C.E. Jews, Christians, and Muslims from the Ancient to the Modern World. Princeton: Princeton University Press, 2001.

Sivan, Hagith. Palestine in Late Antiquity. Oxford: Oxford University Press, 2008.

Skeat, Theodore Cressy, and A. H. M. Jones, "Notes on the Genuineness of the Constantinian Documents in Eusebius's Life of Constantine." The Journal of Ecclesiastical History 5 (1954): p.196-201.

Smith, Jonathan Z. Map is Not Territory: Studies in the History of Religions. Leiden: Brill, 1978.

-. To Take Place: Toward Theory in Ritual. Chicago: University of Chicago Press, 1987.

Smith, Julie Ann. "My Lord's Native Land: Mapping the Christian Holy Land." Church History 76.1 (Mar. 2007): 1-31. 
Stenger, Jan R. "Eusebius and the Representation of the Holy Land." In Brill's Companion to Ancient Geography: The Inhabited World in Greek and Roman Tradition, edited by Serena Bianchetti, Michele R. Cataudella and HansJoachim Gehrke, 381-398. Leiden: Brill, 2016.

Stevens, Wesley M. "The Figure of the Earth in Isidore's "De Natura Rerum"." Isis 71.2 (1980): 268-77.

Stopford, J. Pilgrimage Explored, edited by J. Stopford. Rochester, NY.: York Medieval Press, 1999.

Talbert, J. A. "Author, Audience and the Roman Empire in the Antonine Itinerary" In Herrschen Und Verwalten: Der Alltag der romischen Administration in der Hohen Kaiserzeit. (2007): 256-270.

—. Rome's World: The Peutinger Map Reconstructed. Cambridge: Cambridge University Press, 2010.

Tasker, R. V. G. "The Text Used by Eusebius in Demonstratio Evangelica in Quoting from Matthew and Luke." The Harvard Theological Review 28.1 (1935): 6167.

Taylor, Joan E. Christians and the Holy Places: The Myth of Jewish-Christian Origins. Oxford: Clarendon Press, 1993.

Telfer, William. Cyril of Jerusalem and Nemesius of Emesa. Philadelphia: Westminster Press, 1955.

Tsafrir, Yoram. Ancient Churches Revealed. Jerusalem: Israel Exploration Society, 1993.

—. "Byzantine Jerusalem: The Configuration of a Christian City." In Jerusalem: Its Sanctity and Centrality to Judaism, Christianity, and Islam, edited Lee I. Levine, 133-150. New York: Continuum, 1999.

Turner, Victor-Turner. Image and Pilgrimage in Christian Culture. Lectures on the History of Religions. New York: Columbia University Press, 1995.

Rubin, Zeev. "The Cult of the Holy Places and Christian Politics in Byzantine Jerusalem.” In Jerusalem: Its Sanctity and Centrality to Judaism, Christianity, and Islam, edited Lee I. Levine, 151-162. New York: Continuum, 1999.

Walker, Peter W. L. Holy City, Holy Places?: Christian Attitudes to Jerusalem and the Holy Land in the Fourth Century. Oxford Early Christian Studies. Oxford: Oxford University Press, 1990. 
Wallace-Hadrill, David Sutherland. Eusebius of Caesarea. London: ARMowbray, 1960.

Ward, Walter D. “'In the Province Recently Called Palestine Salutaris': Provincial Changes in Palestine and Arabia in the Late Third and Fourth Centuries C.E." Zeitschrift Für Papyrologie Und Epigraphik 181 (2012): 289-302.

Wharton, Annabel Jane. "The Baptistery of the Holy Sepulcher in Jerusalem and the Politics of Sacred Landscape.” Dumbarton Oaks Papers 46 (1992): 313-25.

Wilken, Robert L. "Loving the Jerusalem Below: The Monks of Palestine." In Jerusalem: Its Sanctity and Centrality to Judaism, Christianity, and Islam, edited Lee I. Levine, 240-250. New York: Continuum, 1999.

Wilkinson, John. Egeria's Travels to the Holy Land, Warminster: Aris \& Phillips 1981.

—. "Constantinian Churches in Palestine." In Ancient Churches Revealed, edited by Toram Tsafrir, 23-39. Jerusalem: Israel Exploration Society, 1993.

—. "Christian Worship in the Byzantine Period." In Ancient Churches Revealed, edited by Toram Tsafrir, 17-22. Jerusalem: Israel Exploration Society, 1993.

—.Egeria's Travels. London: SPCK, 1971.

Wolf, Carl Umhau. "Eusebius of Caesarea and the Onomasticon." The Biblical Archaeologis 27.3 (Sept. 1964): 65-96.

Woodward, David. "Reality, Symbolism, Time, and Space in Medieval World Maps." Annals of the Association of American Geographers 75.4 (1985): 51021. 


\section{Appendix: \\ The Bordeaux Itinerary (585.4-599.9)}

English translations (with some minor emendations by the author) are from Aubrey Stewart in the Palestine Pilgrim Text Society, 1887. Original Latin is from Talbert in Rome's World, 2010.

\begin{tabular}{|c|c|c|c|}
\hline Line Number & English Translation & Original Latin & Type of Reference \\
\hline 585.4 & $\begin{array}{l}\text { City of Caesarea Palaestinae, that is, Judaea - } \\
\text { miles viii. }\end{array}$ & $\begin{array}{l}\text { civitas Caesarea Palestina id est Iudaea } \\
\text { VIII }\end{array}$ & No Reference \\
\hline $585.5-6$ & $\begin{array}{l}\text { Total from Tyre to Caesarea Palaestina } 73 \\
\text { miles, } 2 \text { changes, } 3 \text { halts. }\end{array}$ & $\begin{array}{l}\text { Fit a Tyro Caesarea Palestina milia } \\
\text { LXXIII, mutationes II, mansiones III. }\end{array}$ & No Reference \\
\hline $585.7-8$ & $\begin{array}{l}\text { Here is the bath of Cornelius the centurion } \\
\text { who gave many alms. }\end{array}$ & $\begin{array}{l}\text { Ibi est balneus Cornelii centurionis, qui } \\
\text { multas elymosynas faciebat }\end{array}$ & $\begin{array}{l}\text { Christian } \\
\text { (Acts 10:2; 47-48) }\end{array}$ \\
\hline $585.9-586.2$ & $\begin{array}{l}\text { At the third milestone beyond that place is } \\
\text { Mt. Syna, where there is a fountain, in } \\
\text { which, if a woman bathes, she becomes } \\
\text { pregnant. }\end{array}$ & $\begin{array}{l}\text { Inde est tertio miliario mons Syna, ubi } \\
\text { fons est, in quem mulier est laverit, } \\
\text { gravida fit. }\end{array}$ & $\begin{array}{l}\text { Contemporary } \\
\text { Tradition }\end{array}$ \\
\hline 586.3 & City of Maximianopolis - miles xviii. & civitas Maximianoploi XVIII & No Reference \\
\hline $586.4-5$ & $\begin{array}{l}\text { City of Stradela - miles x. Here reigned King } \\
\text { Achab, and here Helias prophesied. }\end{array}$ & $\begin{array}{l}\text { civitas Isdradela } \mathrm{X} \text { ibi sedit Achab rex et } \\
\text { Helias prophetavit }\end{array}$ & $\begin{array}{l}\text { Jewish } \\
\text { (1 Kings 17) }\end{array}$ \\
\hline
\end{tabular}




\begin{tabular}{|c|c|c|c|}
\hline 586.6 & Here is the field where David killed Goliath. & est campus, ubi David Goliat occidit. & $\begin{array}{l}\text { Jewish } \\
\text { (1 Sam 17:49-51) }\end{array}$ \\
\hline & & & \\
\hline 587.1 & $\begin{array}{l}\text { Aser, where the house of Job was [located] - } \\
\text { miles vi. }\end{array}$ & Aser, ubi fuit villa Iob XVI & Jewish \\
\hline $587.2-5$ & $\begin{array}{l}\text { City of Neapolis - miles xv. Here is Mount } \\
\text { Gerizim. Here the Samaritans say that } \\
\text { Abraham offered sacrifice, and one climbs to } \\
\text { the summit by steps, three hundred in } \\
\text { number. Beyond this, at the foot of the } \\
\text { mountain itself, there is a place by the name } \\
\text { of Schim. }\end{array}$ & $\begin{array}{l}\text { civitas Neapoli XV Ibi est mons } \\
\text { Agazaren: ibi dicunt Samaritani Abraham } \\
\text { sacrificium obtulisse, et ascenduntur } \\
\text { usque ad summum montem gradi numero } \\
\text { MCCC. Inde ad pedem montis ipsius } \\
\text { locus est, cui nomen est Schim. }\end{array}$ & Jewish \\
\hline $587.5-588.1$ & $\begin{array}{l}\text { Here is a tomb in which Joseph is laid, in the } \\
\text { villa which Jacob his father gave to him. }\end{array}$ & $\begin{array}{l}\text { Ibi est monumentum, ubi positus est } \\
\text { Ioseph in villa, quam dedit ei Iacob pater } \\
\text { eius. }\end{array}$ & $\begin{array}{l}\text { Jewish } \\
\text { (Jos 24:32) }\end{array}$ \\
\hline $588.1-2$ & $\begin{array}{l}\text { From that place Dinah, the daughter of } \\
\text { Jacob, was kidnapped by the children of the } \\
\text { Amorites. }\end{array}$ & $\begin{array}{l}\text { Inde rapta est et Dina filia Iacob a filiis } \\
\text { Amorreorum. }\end{array}$ & $\begin{array}{l}\text { Jewish } \\
(\text { Gen } 34: 1-31)\end{array}$ \\
\hline $588.2-5$ & $\begin{array}{l}\text { A mile further on is a place named Sichar, } \\
\text { from which the woman of Samaria came } \\
\text { down to the same place where Jacob dug the } \\
\text { well, so that he might draw water from it, } \\
\text { and our Lord Jesus Christ talked with her. }\end{array}$ & $\begin{array}{l}\text { Inde passus mille locus est cui nomen } \\
\text { Sechar, unde descendit mulier } \\
\text { Samaritana ad eundem locum, ubi Iacob } \\
\text { puteum fodit, ut de eo aquam impleret, et } \\
\text { Dominus noster Iesus Christus cum ea } \\
\text { locutus est; }\end{array}$ & $\begin{array}{l}\text { Christian } \\
\text { (John 4:4-42) }\end{array}$ \\
\hline
\end{tabular}




\begin{tabular}{|c|c|c|c|}
\hline $588.5-6$ & $\begin{array}{l}\text { In which place are plane-trees, which Jacob } \\
\text { planted, and a bath which could be filled } \\
\text { from the well. }\end{array}$ & $\begin{array}{l}\text { ubi sunt et arbores platani, quas plantavit } \\
\text { Iacob, et balneus, qui de eo puteo lavatur. }\end{array}$ & Jewish \\
\hline $588.7-8$ & $\begin{array}{l}\text { Twenty-eight miles from there on the left } \\
\text { hand, as one goes towards Jerusalem, is a } \\
\text { villa named Bethar. }\end{array}$ & $\begin{array}{l}\text { Inde milia XXVIII euntibus Hierusalem } \\
\text { in parte sinistra est villa, quae dicitur } \\
\text { Bethar. }\end{array}$ & No Reference \\
\hline 588.9 & $\begin{array}{l}\text { A mile from further is the place where Jacob } \\
\text { slept when he was journeying into } \\
\text { Mesopotamia. }\end{array}$ & $\begin{array}{l}\text { Inde passus mille est locus, ubi Iacob, } \\
\text { cum iret in Mesopotamiam, addormivit }\end{array}$ & $\begin{array}{l}\text { Jewish } \\
\text { (Gen 28:10-22) }\end{array}$ \\
\hline $588.9-10$ & $\begin{array}{l}\text { Here is the almond tree; here Jacob saw the } \\
\text { vision and the angel wrestled with him. }\end{array}$ & $\begin{array}{l}\text { et ibi est arbor amigdala, et vidit visum et } \\
\text { angelus cum eo luctatus est. }\end{array}$ & $\begin{array}{l}\text { Jewish } \\
\text { (Gen 32:22-32) }\end{array}$ \\
\hline $588.10-589.3$ & $\begin{array}{l}\text { Here was King Jeroboam when the prophet } \\
\text { was sent to him, that he should turn himself } \\
\text { to the Most High God; and the prophet was } \\
\text { ordered not to eat bread with the false } \\
\text { prophet whom the king had with him, and } \\
\text { because he was beguiled by the false prophet } \\
\text { and ate bread with him, as he was returning a } \\
\text { lion fell upon the prophet on the way and } \\
\text { slew him. } \\
\text { Jerusalem }\end{array}$ & $\begin{array}{l}\text { Ibi fuit rex Hieroboam, ad quem missus } \\
\text { propheta, ut converteretur ad Deum } \\
\text { excelsum; et iussum fuerat prophetae, ne } \\
\text { cum pseudoprophetam, quem secum rex } \\
\text { habebat, manducaret, et quia seductus est } \\
\text { a pseudopropheta et cum eo manducavit } \\
\text { rediens, occurrit prophetae leo in via et } \\
\text { occidit eum. }\end{array}$ & $\begin{array}{l}\text { Jewish } \\
\text { (1 Kings 13:1-34) }\end{array}$ \\
\hline 589.4 & Thence to Jerusalem - miles xii. & Inde Hierusalem XII & No Reference \\
\hline
\end{tabular}




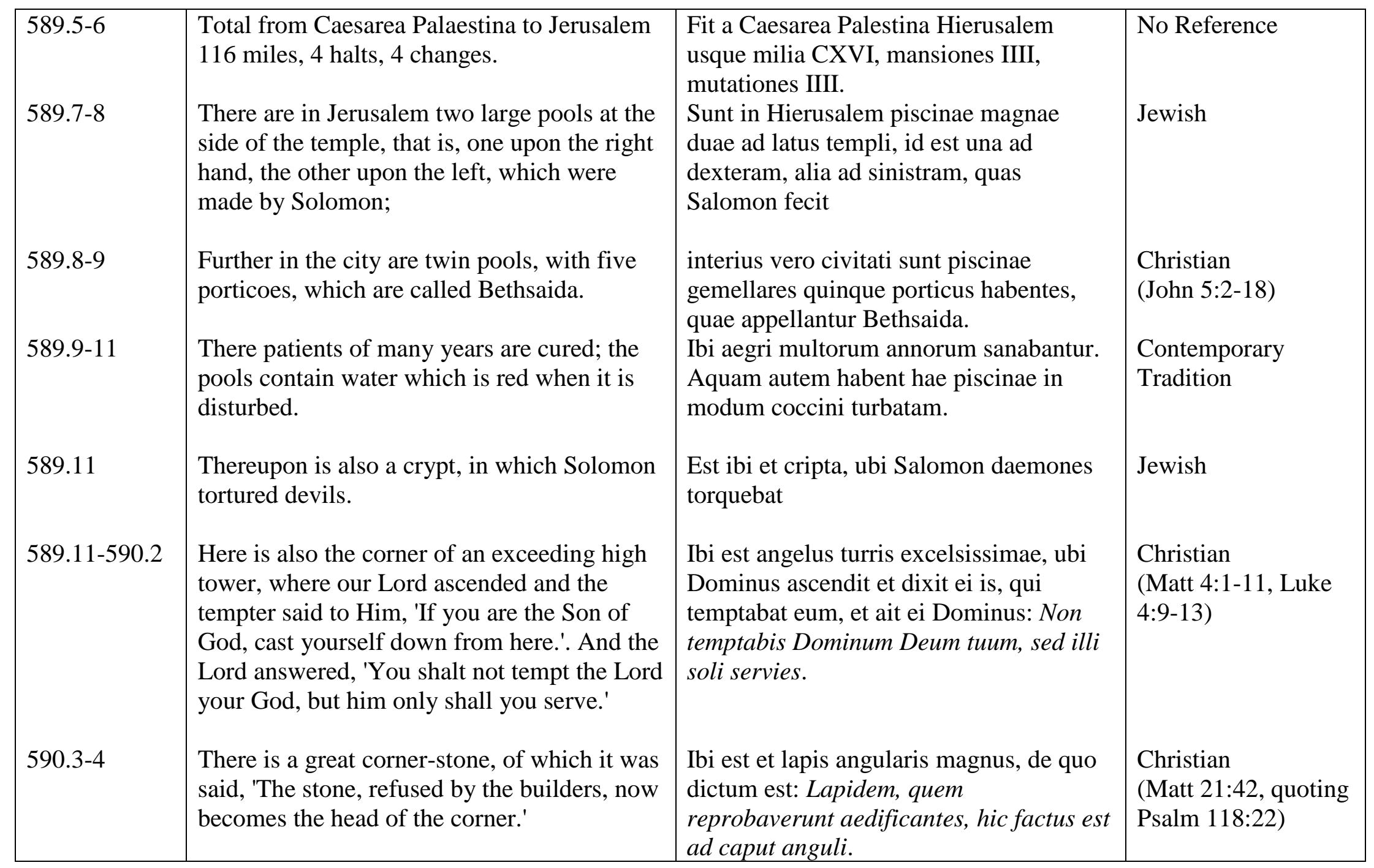




\begin{tabular}{|c|c|c|c|}
\hline $590.4-5$ & $\begin{array}{l}\text { Under the pinnacle of the tower are many } \\
\text { rooms, where Solomon's palace resided. }\end{array}$ & $\begin{array}{l}\text { Et sub pinna turris ipsius sunt cubicula } \\
\text { plurima, ubi Salomon palatium habebat. }\end{array}$ & Jewish \\
\hline $590.5-6$ & $\begin{array}{l}\text { There also is the chamber in which he stayed } \\
\text { and wrote the Wisdom; this chamber is } \\
\text { covered with a single stone. }\end{array}$ & $\begin{array}{l}\text { Ibi etiam constat cubiculus, in quo sedit } \\
\text { et sapientiam descripsit; ipse vero } \\
\text { cubiculus uno lapide est tectus. }\end{array}$ & Jewish \\
\hline 590.6-7 & $\begin{array}{l}\text { There are also large subterranean reservoirs } \\
\text { for water and pools constructed with great } \\
\text { labor. }\end{array}$ & $\begin{array}{l}\text { Sunt ibi et excepturia magna aquae } \\
\text { subterraneae et piscinae magno opere } \\
\text { aedificatae. }\end{array}$ & $\begin{array}{l}\text { Contemporary } \\
\text { Tradition }\end{array}$ \\
\hline 590.7-591.2 & $\begin{array}{l}\text { In the building itself, where stood the temple } \\
\text { which Solomon built, they say that the blood } \\
\text { of Zacharias which was shed upon the stone } \\
\text { pavement before the altar remains to this } \\
\text { day. }\end{array}$ & $\begin{array}{l}\text { Et in aede ipsa, ubi templum fuit, quem } \\
\text { Salomon aedificavit, in marmore ante } \\
\text { aram sanguinem Zachariae ibi dicas } \\
\text { hodie fusum; }\end{array}$ & $\begin{array}{l}\text { Christian } \\
\text { (Matt 23:35, Luke } \\
\text { 11:51) }\end{array}$ \\
\hline $591.2-3$ & $\begin{array}{l}\text { Throughout the enclosure, there are also to } \\
\text { be seen the marks of the spikes in the shoes } \\
\text { of the soldiers who slew him, so plain that } \\
\text { you would think they were impressed upon } \\
\text { wax. }\end{array}$ & $\begin{array}{l}\text { etiam parent vestigia clavorum militum, } \\
\text { qui eum occiderunt, per totum aream, ut } \\
\text { putes in cera fixum esse. }\end{array}$ & $\begin{array}{l}\text { Contemporary } \\
\text { Tradition }\end{array}$ \\
\hline 591.4-6 & $\begin{array}{l}\text { There are two statues of Hadrian, and not far } \\
\text { from the statues there is a perforated stone, to } \\
\text { which the Jews come every year and anoint } \\
\text { it, lament themselves with groans, rend their } \\
\text { garments, and so depart. }\end{array}$ & $\begin{array}{l}\text { Sunt ibi et statuae duae Hadriani; est et } \\
\text { non longe de statuas lapis pertusus, ad } \\
\text { quem veniunt Iudaei singulis annis et } \\
\text { unguent eum et lamentant se cum gemitu } \\
\text { et vestimenta sua scindunt et sic } \\
\text { recedunt. }\end{array}$ & $\begin{array}{l}\text { Contemporary } \\
\text { Tradition }\end{array}$ \\
\hline
\end{tabular}




\begin{tabular}{|c|c|c|c|}
\hline $591.6-7$ & $\begin{array}{l}\text { There also is the house of Hezekiah King of } \\
\text { Judah. }\end{array}$ & Est ibi et domus Ezechiae regis Iudae. & Jewish \\
\hline $591.7-592.2$ & $\begin{array}{l}\text { Also, as you depart from Jerusalem to go up } \\
\text { Mount Sion, on the left hand, below in the } \\
\text { valley, beside the wall, is a pool which is } \\
\text { called Siloe and has four porticoes; and there } \\
\text { is another large pool outside it. }\end{array}$ & $\begin{array}{l}\text { Item exeuntibus Hierusalem, ut ascendas } \\
\text { Sion, in parte sinistra et deorsum in valle } \\
\text { iuxta murum est piscina, quae dicitur } \\
\text { Siloa; habet quadriporticum; et alia } \\
\text { piscina grandis foras. }\end{array}$ & $\begin{array}{l}\text { Christian } \\
\text { (John 9:1-11) }\end{array}$ \\
\hline $592.2-3$ & $\begin{array}{l}\text { This spring runs for six days and nights, but } \\
\text { on the seventh day, which is the Sabbath, it } \\
\text { runs neither in the day nor in the night. }\end{array}$ & $\begin{array}{l}\text { Haec fons sex diebus atque noctibus } \\
\text { currit, septima vero die est sabbatum: in } \\
\text { totum nec nocte nec die currit }\end{array}$ & $\begin{array}{l}\text { Contemporary } \\
\text { Tradition }\end{array}$ \\
\hline $592.3-592.5$ & $\begin{array}{l}\text { On the same route one ascends Sion, and } \\
\text { sees where the house of Caiaphas the priest } \\
\text { was, there still stands a column against } \\
\text { which Christ was beaten with rods. }\end{array}$ & $\begin{array}{l}\text { In eadem ascenditur Sion et paret ubi fuit } \\
\text { domus Caifae sacerdotis, et columna } \\
\text { adhuc ibi est, in qua Christum flagellis } \\
\text { ceciderunt }\end{array}$ & $\begin{array}{l}\text { Christian } \\
\text { (Matt 26:57-68, } \\
\text { Mark 14:53-65, } \\
\text { Luke 22:54-65, John } \\
\text { 18:19-27) }\end{array}$ \\
\hline $592.5-593.1$ & $\begin{array}{l}\text { Within, however, inside the wall of Sion, is } \\
\text { seen the place where was David's palace. Of } \\
\text { seven synagogues which once were there, } \\
\text { one alone remains; the rest are ploughed over } \\
\text { and sown upon, as said Isaiah the prophet. }\end{array}$ & $\begin{array}{l}\text { Intus autem intra murum Sion paret } \\
\text { locus, ubi palatium habuit David. Et } \\
\text { septem synagogae, quae illic fuerunt, una } \\
\text { tantum remansit, reliquae autem arantur } \\
\text { et seminantur, sicut Isaias propheta dixit. }\end{array}$ & $\begin{array}{l}\text { Contemporary } \\
\text { Tradition/ Jewish } \\
\text { Prophecy } \\
\text { (Is 1:2.4-8; Michah } \\
\text { 3:9-12). }\end{array}$ \\
\hline $593.1-3$ & $\begin{array}{l}\text { From there as you go out of the wall of Sion, } \\
\text { as you walk towards the gate of Neapolis, } \\
\text { towards the right, below in the valley, are } \\
\text { walls, where was the house or praetorium of }\end{array}$ & $\begin{array}{l}\text { Inde ut eas foris murum de Sion, euntibus } \\
\text { ad portam Neapolitanam ad partem } \\
\text { dextram deorsum in valle sunt parietes, } \\
\text { ubi domus fuit sive praetorium Pontii }\end{array}$ & $\begin{array}{l}\text { Christian } \\
\text { (Matt 27:11-31, } \\
\text { Mark 15:1-15, Luke } \\
\text { 23:1-25, John 18:28- } \\
\text { 40) }\end{array}$ \\
\hline
\end{tabular}




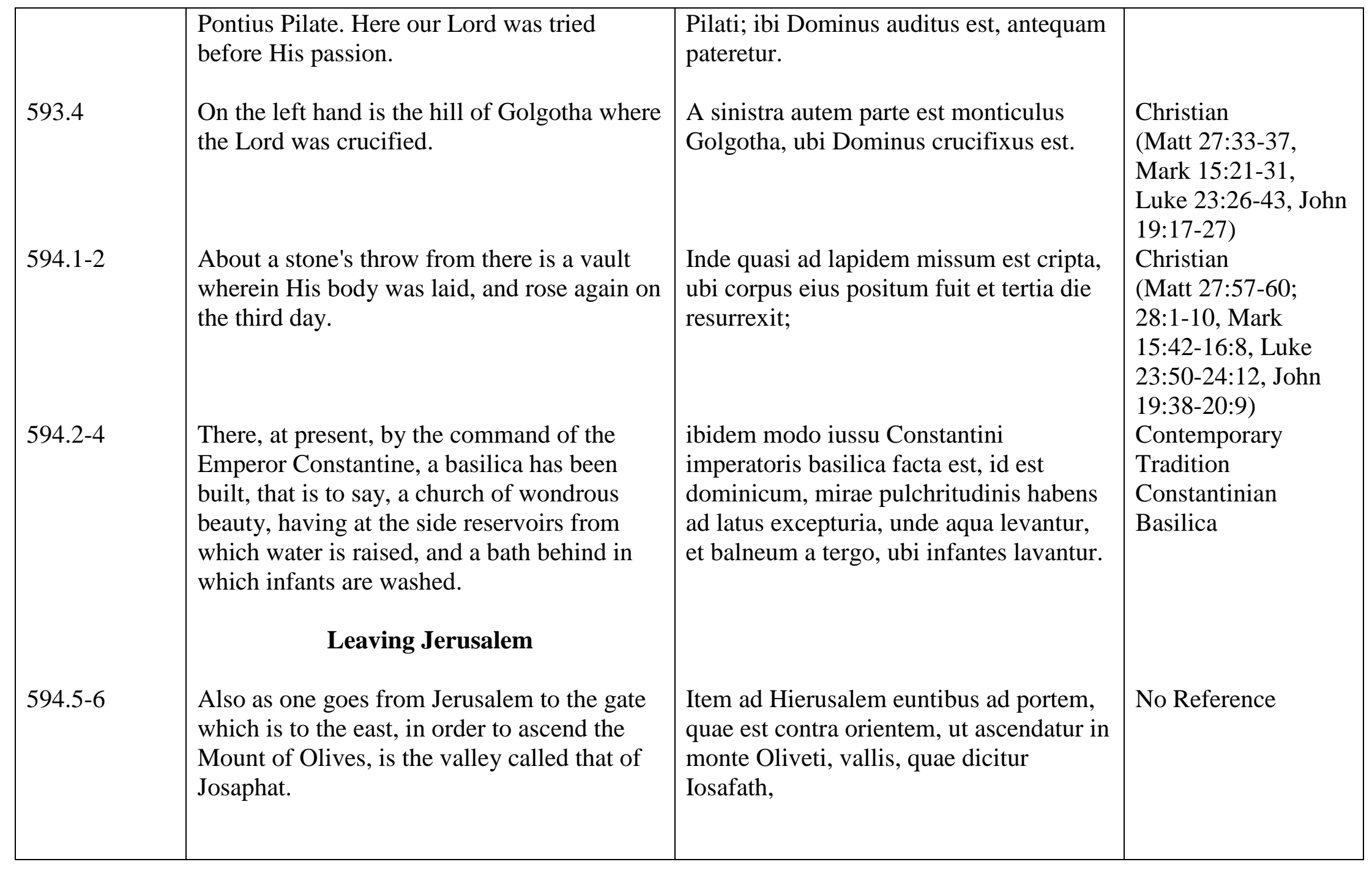




\begin{tabular}{|c|c|c|c|}
\hline $594.6-7$ & $\begin{array}{l}\text { Towards the left, where are the vineyards, is } \\
\text { a stone at the place where Judas Iscariot } \\
\text { betrayed Christ }\end{array}$ & $\begin{array}{l}\text { ad partem sinistram, ubi sunt vineae, est } \\
\text { et petra ubi Iudas Scarioth Christum } \\
\text { tradidit; }\end{array}$ & $\begin{array}{l}\text { Christian } \\
\text { (Matt 26:36-50, } \\
\text { Mark 14:43-44, } \\
\text { Luke 22:47-48, John } \\
\text { 18:1-11) }\end{array}$ \\
\hline $594.7-595.2$ & $\begin{array}{l}\text { On the right is a palm-tree, branches of } \\
\text { which the children carried off and strewed in } \\
\text { the way when Christ came. }\end{array}$ & $\begin{array}{l}\text { a parte vero dextra est arbor palmae, de } \\
\text { qua infantes ramos tulerunt et veniente } \\
\text { Christo substraverunt. }\end{array}$ & $\begin{array}{l}\text { Christian } \\
\text { (Matt 21:1-11, Mark } \\
\text { 11:1-11, Luke } \\
\text { 19:28-40, John } \\
\text { 12:12-19) }\end{array}$ \\
\hline $595.2-4$ & $\begin{array}{l}\text { Not far from there, about a stone's-throw, } \\
\text { two notable tombs of wondrous beauty have } \\
\text { been built; in the one, which is a true } \\
\text { monolith, lies Isaiah the prophet, and in the } \\
\text { other Hezekiah, King of the Jews. }\end{array}$ & $\begin{array}{l}\text { Inde non longe quasi ad lapidis missum } \\
\text { sunt monumenta duo monubiles mirae } \\
\text { pulchritudinis facta: in unum positus est } \\
\text { Isaias propheta, qui est vere monolitus, et } \\
\text { in alio Ezechias rex Iudaeorum. }\end{array}$ & Jewish \\
\hline $595.4-5$ & $\begin{array}{l}\text { From there as you ascend to the Mount of } \\
\text { Olives, where before the Passion, the Lord } \\
\text { taught His disciples }\end{array}$ & $\begin{array}{l}\text { Inde ascendis in montem Oliveti, ubi } \\
\text { Dominus ante passionem apostolos } \\
\text { docuit: }\end{array}$ & $\begin{array}{l}\text { Christian } \\
\text { (Matt 24-25) }\end{array}$ \\
\hline $595.5-6$ & $\begin{array}{l}\text { There by the orders of Constantine a basilica } \\
\text { of has been built. }\end{array}$ & ibi facta est basilica iussu Constantini. & $\begin{array}{l}\text { Contemporary } \\
\text { Tradition } \\
\text { Constantinian } \\
\text { Basilica }\end{array}$ \\
\hline $595.6-596.1$ & $\begin{array}{l}\text { Not far from there is the little hill which the } \\
\text { Lord ascended to pray, when he took Peter } \\
\text { and John with Him, and Moses and Elisha } \\
\text { were beheld. }\end{array}$ & $\begin{array}{l}\text { Inde non longe est monticulus, ubi } \\
\text { Dominus ascendit orare et apparuit illic } \\
\text { Moyses et Helias, quando Petrum et } \\
\text { Iohannem secum duxit. }\end{array}$ & $\begin{array}{l}\text { Christian } \\
\text { (Matt 17:1-8, Mark } \\
\text { 9:2-8, Luke 9:28-36) }\end{array}$ \\
\hline
\end{tabular}




\begin{tabular}{|c|c|c|c|}
\hline & & & \\
\hline $596.1-3$ & $\begin{array}{l}\text { A mile and a half to the east is the village } \\
\text { called Bethany. There is a crypt in which } \\
\text { Lazarus, whom the Lord raised, was laid. }\end{array}$ & $\begin{array}{l}\text { Inde ad orientem passus mille quingentos } \\
\text { est villa, quae appellatur Bethania; est ibi } \\
\text { cripta, ubi Lazarus positus fuit, quem } \\
\text { Dominus suscitavit. }\end{array}$ & $\begin{array}{l}\text { Christian } \\
\text { (John 11:1-44) }\end{array}$ \\
\hline 596.4 & From Jerusalem to Jericho - miles xviii. & $\begin{array}{l}\text { Item ad Hierusalem in Hiericho milia } \\
\text { XVIII }\end{array}$ & No Reference \\
\hline 596.4-596.6 & $\begin{array}{l}\text { As one descends from the mount, behind a } \\
\text { tomb, is the sycamore tree into which } \\
\text { Zacchaeus climbed that he might see Christ. }\end{array}$ & $\begin{array}{l}\text { Descendentibus montem in parted extra } \\
\text { retro monumentum est arbor sicomori, in } \\
\text { qua Zachaeus ascendit, ut Christum } \\
\text { videret. }\end{array}$ & $\begin{array}{l}\text { Christian } \\
\text { (Luke 19:1-10) }\end{array}$ \\
\hline $596.6-10$ & $\begin{array}{l}\text { A mile-and-a-half from the town is the } \\
\text { fountain of the prophet Elisha. Before, if any } \\
\text { woman drank from its water, she did not bear } \\
\text { children. Beside it lies an earthenware vessel. } \\
\text { Elisha threw salt into it, and came and stood } \\
\text { over the fountain and said, 'Thus said the } \\
\text { Lord, I have cleansed these waters.' If any } \\
\text { woman drink of this fountain she shall bear } \\
\text { children. }\end{array}$ & $\begin{array}{l}\text { A civitate, passus mille quingentos est ibi } \\
\text { fons Helisei prophetae. Antea si qua } \\
\text { mulier ex ipsa aqua bibebat, non faciebat } \\
\text { natos. Adlatum est vas fictile Heliseo, } \\
\text { misit in eo sales et venit et stetit super } \\
\text { fontem et dixit: Haec dicit Dominus: } \\
\text { sanavit aquas has. Ex eo si qua mulier } \\
\text { inde biberit, filios faciet. }\end{array}$ & $\begin{array}{l}\text { Jewish } \\
\text { (2 Kings } 2: 1-22)\end{array}$ \\
\hline $596.10-597.2$ & $\begin{array}{l}\text { Above the same fountain is the house of the } \\
\text { harlot Rahab, to whom the spies came, and } \\
\text { she hid them, and alone was saved when } \\
\text { Jericho was destroyed. }\end{array}$ & $\begin{array}{l}\text { Supra eundem vero fontem est domus } \\
\text { Rachab fornicariae, ad quam exploratores } \\
\text { intrierunt et occultavit eos, quando } \\
\text { Hiericho eversa est, et sola evasit. }\end{array}$ & $\begin{array}{l}\text { Jewish } \\
\text { (Jos 2:1-21; Heb } \\
11: 17-40)\end{array}$ \\
\hline $597.2-3$ & $\begin{array}{l}\text { Here stood the city of Jericho, around whose } \\
\text { walls the children of Israel circled with the } \\
\text { Ark of the Covenant, and the walls fell. }\end{array}$ & $\begin{array}{l}\text { Ibi fuit civitas Hiericho, cuius muros } \\
\text { gyraverunt cum arca testament filii Israel } \\
\text { et ceciderunt muri. }\end{array}$ & $\begin{array}{l}\text { Jewish } \\
\text { (Jos 6:1-25) }\end{array}$ \\
\hline
\end{tabular}




\begin{tabular}{|c|c|c|c|}
\hline $597.3-5$ & $\begin{array}{l}\text { Nothing is to be seen of it except the place } \\
\text { where the Ark of the Covenant stood, and the } \\
\text { twelve stones which the children of Israel } \\
\text { brought out of Jordan. }\end{array}$ & $\begin{array}{l}\text { Ex eo non paret nisi locus, ubi fuit arca } \\
\text { testament et lapides XII, quos filii Israel } \\
\text { de Iordane levaverunt. }\end{array}$ & $\begin{array}{l}\text { Jewish } \\
\text { (Jos 4:1-24) }\end{array}$ \\
\hline $597.5-6$ & $\begin{array}{l}\text { There Joshua the son of Nun circumcised the } \\
\text { children of Israel and buried their foreskins. }\end{array}$ & $\begin{array}{l}\text { Ibidem Iesus filius Nave circumcidit } \\
\text { filios Israel, et circumcisions eorum } \\
\text { sepelivit. }\end{array}$ & $\begin{array}{l}\text { Jewish } \\
(\text { Jos 5:2-9) }\end{array}$ \\
\hline 597.7-10 & $\begin{array}{l}\text { From Jericho to the Dead sea - miles ix. Its } \\
\text { water is very bitter, and in it there exists } \\
\text { neither any kind of fish nor any vessel; and if } \\
\text { a man casts himself into it in order to swim, } \\
\text { the water turns him over. }\end{array}$ & $\begin{array}{l}\text { Item ad Hiericho ad Mare Mortuum milia } \\
\text { novem. Est aqua ipsius valde amarissima, } \\
\text { ubi in totum nullius generis piscis est nec } \\
\text { aliqua navis, et si qui hominum miserit } \\
\text { se, ut natet, ipsa aqua eum versat. }\end{array}$ & $\begin{array}{l}\text { Contemporary } \\
\text { Tradition }\end{array}$ \\
\hline $598.1-2$ & $\begin{array}{l}\text { From there to the Jordan, where the Lord was } \\
\text { baptized by John - miles v. }\end{array}$ & $\begin{array}{l}\text { Inde ad Iordane, ubi Dominus a Iohanne } \\
\text { baptizatus, est milia quinque. }\end{array}$ & $\begin{array}{l}\text { Christian } \\
\text { (Matt 3:13-17, Mark } \\
\text { 1:9. Luke 3:21) }\end{array}$ \\
\hline 598.3 & $\begin{array}{l}\text { There is a place above the river, a little hill } \\
\text { upon the further bank, from which Elijah was } \\
\text { caught up into heaven. }\end{array}$ & $\begin{array}{l}\text { Ibi est locus super flumen, monticulus in } \\
\text { illa ripa, ubi ratus est Helias in caelum. }\end{array}$ & $\begin{array}{l}\text { Jewish } \\
\text { (2 Kings } 2: 1-15)\end{array}$ \\
\hline 598.4-5 & $\begin{array}{l}\text { From Jerusalem going to Bethlehem - miles } \\
\text { iv. On the road, on the right hand, is a tomb, } \\
\text { in which lies Rachel, the wife of Jacob. }\end{array}$ & $\begin{array}{l}\text { Item ad Hierusalem euntibus Bethleem } \\
\text { milia quattuor super strata in parted extra } \\
\text { est monumentum, ubi Rachel posita est, } \\
\text { uxor Iacob. }\end{array}$ & $\begin{array}{l}\text { Jewish } \\
\text { (Gen 35:16-20; Matt } \\
\text { 2:16-18) }\end{array}$ \\
\hline $598.5-6$ & $\begin{array}{l}\text { Two miles from there, on the left hand, is } \\
\text { Bethlehem, where our Lord Jesus Christ was } \\
\text { born }\end{array}$ & $\begin{array}{l}\text { inde milia duo a parte sinistra est } \\
\text { Bethleem, ubi natus est Dominus Iesus } \\
\text { Christus; }\end{array}$ & $\begin{array}{l}\text { Christian } \\
\text { (Matt 2:18-25; Luke } \\
\text { 2:1-7) }\end{array}$ \\
\hline
\end{tabular}




\begin{tabular}{|c|c|c|c|}
\hline 598.7 & $\begin{array}{l}\text { A basilica has been built there by the orders } \\
\text { of Constantine. }\end{array}$ & ibi basilica fact est iussu Constantini. & $\begin{array}{l}\text { Contemporary } \\
\text { Tradition } \\
\text { Constantinian } \\
\text { Basilica }\end{array}$ \\
\hline $598.7-9$ & $\begin{array}{l}\text { Not far from there is the tomb of Ezekiel, } \\
\text { Asaph, Job, Jesse, David, and Solomon, } \\
\text { whose names are inscribed in Hebrew letters } \\
\text { upon the wall as you go down into the vault } \\
\text { itself. }\end{array}$ & $\begin{array}{l}\text { Inde non longeest monumentum } \\
\text { Ezechiel. Asaph, Iob et Iesse, David, } \\
\text { Solomon, et habet ipsa cripta ad latus } \\
\text { deorsum descendentibus hebraeis litteris } \\
\text { scriptum nomia supra scripta. }\end{array}$ & Jewish \\
\hline $599.1-2$ & $\begin{array}{l}\text { From there to Bethasora - miles xiv. There is } \\
\text { the fountain in which Philip baptized the } \\
\text { eunuch. }\end{array}$ & $\begin{array}{l}\text { Inde Bethasora milia XIIII, ubi est fons, } \\
\text { in quo Philippus eunuchum baptizavit }\end{array}$ & $\begin{array}{l}\text { Christian } \\
\text { (Acts 8:26-40) }\end{array}$ \\
\hline $599.3-5$ & $\begin{array}{l}\text { Then to Terebinthus - miles viii. Here } \\
\text { Abraham dwelt, and dug a well under a } \\
\text { terebinth tree, and spoke with angels, and ate } \\
\text { food with them. }\end{array}$ & $\begin{array}{l}\text { Inde Terebinto milia VIIII, ubi Abraham } \\
\text { habitavit et puteum fodit sub abore } \\
\text { terebintho et cum angelis locutus est et } \\
\text { cibum sumpsit; }\end{array}$ & $\begin{array}{l}\text { Christian } \\
\text { (Gen 18:1-14) }\end{array}$ \\
\hline $599.5-6$ & $\begin{array}{l}\text { Here a basilica of wondrous beauty has been } \\
\text { built by the command of Constantine. }\end{array}$ & $\begin{array}{l}\text { Ibi basilica facta est iussu Constantini } \\
\text { mirae puchritudinis. }\end{array}$ & $\begin{array}{l}\text { Contemporary } \\
\text { Tradition } \\
\text { Constantinian } \\
\text { Basilica }\end{array}$ \\
\hline $599.7-9$ & $\begin{array}{l}\text { From Terebinthus to Hebron - miles ii. Here } \\
\text { is a monument of square form built of stone } \\
\text { of wondrous beauty, in which lie Abraham, } \\
\text { Isaac, Jacob, Sara, Rebecca, and Leah. }\end{array}$ & $\begin{array}{l}\text { Inde Terebinto Cebron milia II, ubi est } \\
\text { memoria per quadrum ex lapidibus mirae } \\
\text { pulchritudinis, in qua positi sunt } \\
\text { Abraham, Isaac, Iacob, Sarra, Rebecca et } \\
\text { Lia. }\end{array}$ & $\begin{array}{l}\text { Jewish } \\
(\text { Gen 23:1-19; 25:7- } \\
\text { 10; 49:29-43) }\end{array}$ \\
\hline
\end{tabular}

